\title{
THE CONTROL OF BREATHING AT HIGH ALTITUDE
}

J.S. Milledge, M.B.Ch.B. (B'ham), M.R.C.P. Edin.

Thesis submitted in fulfillment of requirements for the M.D. in Medicine

University of Birmingham

1968 


\section{UNIVERSITYOF BIRMINGHAM}

\section{University of Birmingham Research Archive \\ e-theses repository}

This unpublished thesis/dissertation is copyright of the author and/or third parties. The intellectual property rights of the author or third parties in respect of this work are as defined by The Copyright Designs and Patents Act 1988 or as modified by any successor legislation.

Any use made of information contained in this thesis/dissertation must be in accordance with that legislation and must be properly acknowledged. Further distribution or reproduction in any format is prohibited without the permission of the copyright holder. 


\section{TABLE OF CONTENTS}

Page

Synops is 1

Acknowledgments $\quad 2$

Chapter I Introduction

1. Historical 4

2. Setting of Present Study 10

Chapter II Changes in Ventilatory Response to $\mathrm{CO}_{2}$ and

$\mathrm{O}_{2}$ on Acclimatization to High Altitude 17

Chapter III Respiration During Exercise at High Altitude 41

Chapter IV Ventilatory Response to $\mathrm{CO}_{2}$ and $\mathrm{O}_{2}$ in Sherpa

Highlanders 62

Chapter $V \quad$ Ventilation during Exercise in Sherpas 82

Chapter VI Blood and CSF Acid-Base Ba lance in Man at 99

High A1titude 
$S Y N O P$ S I S

The changes in the control of breathing in man at high altitude have been studied at $5,800 \mathrm{~m}(19,000 \mathrm{ft})$. The differences between $10 \mathrm{w}-$ landers and Sherpas were compared at 4,880 m (16,000 ft.). Ventilatory response to $\mathrm{CO}_{2}$, hypoxia and exercise were studied, and acid-base status of the blood and CSF measured.

Acclimatization to altitude is characterized by a shift of the $\mathrm{CO}_{2}$ response curve to the left and an increase in its slope. The hypoxic sensitivity appears unchanged. On moderate exercise there results a progressive increase in ventilatory equivalent with increasing altitude. At maximum work rate ventilation increases more rapidly due to falling $\mathrm{SaO}_{2} \cdot$

Sherpas show no significant difference in response to $\mathrm{CO}_{2}$ but a remarkable lack of response to hypoxia. The $\mathrm{CO}_{2}$ response showed little change in slope with change of $\mathrm{PO}_{2}$ and on exercise acutely changing $\mathrm{P}_{1} \mathrm{O}_{2}$ had little effect on ventilation. Sherpas ventilate less on exercise and have higher maximum $\mathrm{O}_{2}$ intakes per $\mathrm{kg}$ than lowlanders.

The arterial $\mathrm{pH}$ of highlanders is normal whereas in lowlanders it remains slightly elevated after $4-6$ weeks at altitude. CSF pH of highlanders is about 0.04 units more acid than lowlanders at the same altitude, indicating a greater central contribution to respiratory drive and a reduced peripheral component. The role of anaerobic cerebral metabolism in respiratory acclimatization is discussed. 


\section{A CKN OWLEDGMENTS}

This work was carried out over eight years in many places and therefore I am indebted to many people who helped me as collaborators or subject: and often both. To others I am indebted for their advice, supervision and laboratory facilities.

From the first expedition (1960-61) I am chiefly indebted to Dr. L. G. C. Pugh who planned and led the scientific side of the expedition and to Sir Edmund Hillary the leader who with Dr. Pugh invited me to join the team. The work on $\mathrm{CO}_{2}$ and hypoxic response was under the supervision of Dr. D. J. C. Cunningham and Mr B. B. Lloyd whose teaching and advice are gretefully acknowledged, together with the valuable collaboration of Dr. C. C. Miche11, al1 of the Department of Physiology, University of 0xford. I am indebted to all the expedition team who acted as subjects, and to Dr. J. B. West who also taught me much physiology. I acknowledge my thanks to R. A. F. Institute of Aviation medicine, Farnbrough, for allowing me to use their low pressure chamber for follow-up experiments. On the second expedition (1964) I am again indebted to Sir Edmund Hillary for all the field facilities, and to Dr. S. Lahiri who organized the scientific aspect of the expedition as well as acting as collaborator and subject. Also Mr. Battacharia who assisted us in the work and was a subject. Our Sherpas not only volunteered as subjects but also looked after our comforts (on both expeditions). Without their cheerful help nothing would have been accomplished. I acknowledge the help and facilitie 
afforded by Dr. P. Zechariah in his Department of Physiology at Vellore for the follow-up studies after the expedition.

The work in Peru, briefly reported in the last chapter, was largely due to the initiative of Dr. S. Sфrensen and the encouragement of Dr. J. W. Severinghaus to whom I am very grateful. I wish also to thank Dr. J. Cruz and the Institudo de Investigazione de1 Altura in Lima for help and facilities in Peru.

Financially I am indebted to the following organizations: World Book Encyclopaedia for sponsorship of the 1960-61 expedition; The Medical Research Council for its sponsorship and for a personal grant following it; The Indian Council for Medical Research for a grant supporting the physiological programme of the second expedition (1964); The American Thoracic Society for the fellowship which supported me in San Francisco when this thesis was completed and during the visit to Peru; and the National Institute of Health (Grant No. USPHS HE-06285) which supported the expenses of the visit to Peru. 
C H A P T E R I

INTRODUCTION I

Historical

From earliest times the vital importance of breathing has been recognized. The author of the book of Genesis writes, "And the Lord God formed man ... and breathed into his nostrils the breath of 1ife; and man became a living being" (Gen 2:7).

The Hebrew word neshema translated in the quotation as "breath of life" can mean breath or life force. In the early Hebrew philosophy man was formed from the dust and became a living being only by God breathing into him the "neshema" of life or "ruach" God's spirit. Death was the departure from man of this same "breath" and man again became dust.

In Greek phi losophy of about the same era, ie. about 500 B.C. the work "pneuma" had very much the same connotation as neshema. Anaximines of Miletus (born circa 570 B.C.) said "As our soul being air, sustaining us, so pneuma and air pervade the whole world" (Perkins 1964).

The deep-rooted idea of an intimate connection between breathing and life is shown in modern language by our use of the words inspire and expire. 
But although it was realized that life in some way depended entirely upon breathing, no scientific investigation of this connection was possible until the second half of the 18 th century when the discovery of carbon dioxide by Black, and of oxygen by Priestly and Scheele set the stage for the brilliant work of Lavoisier showing that in respiration animals consumed $\mathrm{O}_{2}$ and produced $\mathrm{CO}_{2}$. The first systemic study of the effects of $\mathrm{O}_{2}$ lack and $\mathrm{CO}_{2}$ inhalation was by Pflüger (1868). He came to the conclusion that $\mathrm{O}_{2}$ lack was more important in the control of respiration. This was probably because he used 30 per cent $\mathrm{CO}_{2}$ which would produce a degree of narcosis in his dogs.

MiescherRusch (1885) concluded that $\mathrm{CO}_{2}$ was the more potent stimulus since in his human subjects the inhalation of $\mathrm{CO}_{2}$ sufficient to cause dyspnoea caused the expired $\mathrm{CO}_{2}$ concentration to rise from 5.43 per cent to on $1 y$ 6.0-6.4 per cent. He wrote "Thus carbonic acid spreads its protective wings over the oxygen needs of the body." In 1877 Walter demonstrated an increase in respiration in dogs poisoned with acid thus identifying the third main chemical stimulus to breathing.

Between 1870 and 1885 Paul Bert carried out many experiments on the effects of reduced pressure and oxygen breathing and showed that "Oxygen tension is everything, barometric pressure in itself does nothing or almost nothing." Thus laying a sure foundation for all future work on chemical control of breathing and altitude physiology.

Despite the work of Miescher Rush and others, by the turn of the century there was sti 11 much controversy as to the normal contro 1 of breathing. 
In $1905 \mathrm{Ha}$ ldane and Priestly published their classical paper demonstrating the constancy of the alveolar $\mathrm{PCO}_{2}$ over a range of barometric pressures, varying from $646 \mathrm{~mm} \mathrm{Hg}$ on top of Ben Nevis to $1,260 \mathrm{~mm}$ in the Brompton hospital pressure chamber. They also showed the great sensitivity of man to small increments of inspired $\mathrm{CO}_{2}$ and concluded that under normal circumstances $\mathrm{CO}_{2}$ regulated the respiration.

Haldane realized the importance of acid and later with Douglas (1909) noted the fall in $\mathrm{PaCO}_{2}$ after hard exercise and attributed it to lactic acid production by the muscles. The possibility that $\mathrm{CO}_{2}$ exerted its effect through its acidity was obvious and was proposed formally in Winterstein's "reaction theory". This theory as first proposed in 1910 was found inadequate since $\mathrm{CO}_{2}$ had a greater effect on respiration than an equivalent quantity of infused acid. A possible cause for this was given by Jacobs (1920) who showed that living membranes, in this case the lining membrane of Arbacia eggs, can be more freely permeable to dissolved $\mathrm{CO}_{2}$ than to hydrogen ions. Winterstein (1956) therefore modified his theory suggesting that the CSF $\left[\mathrm{H}^{+}\right]$was the controlling factor rather than the blood $\left[\mathrm{H}^{+}\right]$and that $\mathrm{CSF}\left[\mathrm{H}^{+}\right]$was affected readily by changes in $\mathrm{PaCO}_{2}$ but not by arterial pH changes due to infusion or production of acids.

This reaction theory did not, of course, account for hypoxic stimulation. The discovery of peripheral chemoreceptors by Heymans and Heymans in 1927 led to the thought that whilst $\mathrm{CO}_{2}$ and/or $\mathrm{H}^{+}$ affected mainly central receptors near the respiratory center, hypoxia affected mainly the peripheral receptors. It seemed unlikely, therefore, that a single unique stimulus to breathing could be proposed. 
In 1950 Gray published his multifactorial theory in which he took the view that al1 three known stimuli contributed to the total ventilation. Also that these effects could be quantitated and added algebraically to give the resultant ventilation for any given set of values for $\mathrm{Po}_{2} \mathrm{PCO}_{2}$ and $\mathrm{pH}$. He worked from data in the literature and proposed the formula:

$$
\mathrm{VR} \cdot \mathrm{H}^{+} \cdot \mathrm{PCO}_{2} \cdot \mathrm{PO}_{2}=0.22 \mathrm{H}^{+}+0.262 \mathrm{PcO}_{2}-18+2.118\left(104-\mathrm{Po}_{2}\right)^{4.9}
$$

This acted as a considerable stimulus to respiratory physiologists to undertake further experiments to prove or disprove his theory. Workers in Scandinavia and in Oxford examined again the effects of hypoxia and $\mathrm{CO}_{2}$ on the ventilation. Nielsen and $\mathrm{Smith}$ showed in 1951 that these two well known stimuli were not additive as Gray's theory assumed, but interacted, so that the effect of hypoxia became greater as the $\mathrm{PCO}_{2}$ was raised. The oxford workers found the same interaction (Cunningham, Cormack and Gee 1957, and Lloyd Jukes and Cunningham 1958). The ventilatory response to $\mathrm{CO}_{2}$ above certain critical threshold is linear. Examining this linear portion of the line, they found that as the $\mathrm{PO}_{2}$ was lowered, a family of response lines was made, which when produced back to the $\mathrm{PCO}_{2}$ axis came to a single point on this axis, thus forming a fan of lines. They derived an equation to describe this, relating ventilation $(\dot{V})$ to alveolar $\mathrm{Pco}_{2}$ and $\mathrm{Po}_{2}$ through four parameters: B, D, C and A

$$
\dot{V}=D\left(P \mathrm{PO}_{2}-B\right)\left\{1+\frac{A}{\left(\mathrm{PO}_{2}-\mathrm{C}\right)}\right\}
$$


where $\mathrm{B}$ is the intercept of the $\mathrm{CO}_{2}$ response lines extrapolated to the $\mathrm{PCO}_{2}$ axis.

$D$ is the minimum slope of the $\mathrm{CO}_{2}$ response lines, i.e., when $\mathrm{PO}_{2}$ is infinite and therefore there is no hypoxic drive. It is expressed in 1 iters per min per $\mathrm{mm} \mathrm{Hg} \mathrm{PcO}_{2}$.

$C$ is the value for $\mathrm{PO}_{2}$ when the slope is infinite, and

$A$ is related to oxygen sensitivity, actually to the shape of the hyperbola relating $\mathrm{PO}_{2}$ to the slope of the $\mathrm{CO}_{2}$ response line expressed in $\mathrm{mm} \mathrm{Hg} \mathrm{PO} 2$.

This equation: is purely descriptive and does not tell us anything about the mechanism of action of $\mathrm{CO}_{2}$ and hypoxia, but as a quantitative statement of their separate effects on ventilation it is very useful in comparing individuals under varying experimental conditions, or in comparing one group with another.

\section{RESPIRATION AT ALTITUDE}

Early accounts of the study of respiration at altitude focus on acute mountain sickness. The first of such accounts was by the Spanish Jesuit Fr. Jose de Acosta in 1590 (Ke1logg, 1967), who tells very vividly of his own and others' experiences in crossing the high Andean passes. After describing the headache, nausea, vomiting, etc. of the condition, he hints at the process of acclimatisation. He noted that those coming westward from the altoplano were less affected -having had at least a few days at high altitude -- than those going east who came rapidly up from the coast. 
Denis Jourdanet (1861), a French physician who travelled extensively in Mexico and South America noted the similarity between mountain sickness and anaemia and suggested oxygen lack as being the cause of symptoms in both conditions. It was Jourdanet who stimulated and financed Paul Bert in his work on altitude.

Although difficulty and increase in breathing was known to be part of the response to high altitude, when the first quantitative study was reported by Mosso in 1897, he apparently found resting ventilation to be reduced. The reason for his error was partly due to his methods -- he used a poorly calibrated plethysmograph to measure ventilation, and partly conceptual since he expressed his results in $1 / \mathrm{min}$ STPD. He also found the $\mathrm{P}_{\mathrm{E}} \mathrm{CO}_{2}$ to be reduced and attributed mountain sickness to this cause. Ward (1908) found a lowered $P_{A} c 02$ in subjects on Monte Rosa, and this was confirmed in 1910 by Barcroft and Douglas on the Teneriffe expedition who noted that those members with the lowest $\mathrm{P}_{A} \mathrm{CO}_{2}$ were most free of symptoms.

This fall in $\mathrm{P}_{\mathrm{A}} \mathrm{CO}_{2}$ was most intensely studied by Douglas, Haldane, Henderson and Schneider (1913) on the 1911 Pikes Peak expedition and they suggested that during acclimatization man becomes "more sensitive to $\mathrm{CO}_{2}$." While they were up Pike's Peak Miss Fitzgerald (1914) also from the Oxford physiology school toured the mining communities of Colorado on mule back. Shj analyzed alveolar gas samples for $\mathrm{P}_{A} \mathrm{CO}_{2}$ in the residents there. She showed in these people a fall in $\mathrm{P}_{A} \mathrm{CO}_{2}$ that was approximately linear with decreasing barometric pressure.

The high altitude expeditions between the wars were not concerned with respiratory control beyond the collection of alveolar gas samples. 
After World War II there has been greatly renewed interest in the subject; and many studies have been carried out at altitude in North and South America, Europe and a few in the Himalayas. This work is discussed in the succeeding chapters of this thesis.

I.NTRODUCTION II

Setting of Present Study

The work described in this thesis is mainly the result of two scientific expeditions to the Himalayas in 1960 and 1964 with preliminary results from a visit to the Peruvian Andes in 1968. Together with preliminary and follow-up experiments, the work spans a time from March 1960 to Apri 1968 and was carried out in the field and in the following laboratories:

The Department of Physiology, University of Oxford, U.K.

The Medical Research Council Laboritories, Holly Hi11, Hampstead, U.K.

The R.A.F. School of Aviation Medicine, Farnbrough, U.K. Department of Physiology, Presidency College, Calcutta, India Department of Physiology, Christian Medical College, Vellore, India

The first expedition, "The 1960-61 Himalayan and Scientific and Mountaineering Expedition" was led by Sir Edmund Hillary, with Dr. L. G. C. E. Pugh as scientific leader. The area of operation was 
the Everest region of Eastern Nepal known as Solu Khumbu. Besides the scientific work, physiology and glaciology, the expedition had as its mountaineering objective the assault of Mount Makalu without oxygen and an investigation into the existence of the Yeti or Abominable Snowman. The results of these are described by Hillary and Doig in the expedition book (Hillary and Doig 1962).

The physiological objective was to study the changes in the physiology of normal lowland man on ascent and prolonged stay at high altitude. A list of publications from this expedition, showing the scope of this work, is given in the appendix to this chapter.

As part of this work, two series of experiments bearing on the control of respiration were undertaken; one at rest, on the venti1atory response to changing inspired $\mathrm{PCO}_{2}$ and $\mathrm{PO}_{2}$, and the other at exercise, with varying rates of work. These experiments and the sea level control experiments form the basis of the first part of this thesis.

In order to spend a long period at altitude, it was necessary for us to start just after the monsoon, in September 1960, and spend the winter at high altitude, returning before the next monsoon, in June 1961. This was the first time that men have spent the winter at high altitude in the Himalayas. In order to study the effects of really high altitude, it was intended to establish a station at $20,000 \mathrm{ft}$. In the event a suitable site could not be found above $19,000 \mathrm{ft}(5,800 \mathrm{~m})$. We found that even this height was probably above that at which lowland man, even acclimatised, could live indef initely since after the first month we began to lose weight despite an apparently adequate diet. 
This high altitude station, known as the Silver Hut consisted of a prefabricated hut (see photograph) almost cylindrical in section, $22 \mathrm{ft}$ long by $10 \mathrm{ft}$ diameter. Inside were bunks, table, stove, laboratory space, benches, etc. The hut was specially designed and built for us in plywood sections. All parts, as well as the equipment and food had to be carried by porters for 18 days into the area, then three days up from the last village. The hut was wel1 insulated and daytime temperatures inside varied from 60 to $80^{\circ} \mathrm{F}\left(21\right.$ to $29^{\circ} \mathrm{C}$ ).

Some exercise experiments were also carried out at the Mingbo base camp (a tented camp) at $15,300 \mathrm{ft}(4,630 \mathrm{~m})$.

The physiological programme was continued in the spring during the attempted assault on Mount Makalu $(27,800 \mathrm{ft}, \cdots 8,450 \mathrm{~m})$. At advanced base camp $(21,000 \mathrm{ft}, 6,400 \mathrm{~m})$ and on the Makalu Col $(24,000 \mathrm{ft}$, $7,440 \mathrm{~m}$ ) exercise experiments were carried out, and alveolar gas samples were collected at these stations and at camp VI, $(25,700 \mathrm{ft}, 7,830 \mathrm{~m})$. The members of the physiology team were:

Dr. L. G. C. E. Pugh of the Medical Research Counci1, London Mr. (now Dr.) M. B. Gill of Auckland, New Zealand

Dr. S. Lahiri of Presidence College, Calcutta Dr. M. P. Ward of the London Hospital Dr. J. S. West of the Hammersmith Post-Graduate Medical School and the author.

The second expedition in 1964 was smaller and less ambitious than the 1960-61 expedition; this, the "Second School House Expedition" was one of a series led by Sir Edmund Hillary, primarily to continue his aid programme for the Sherpas of Solu Khumbu. The physiological 


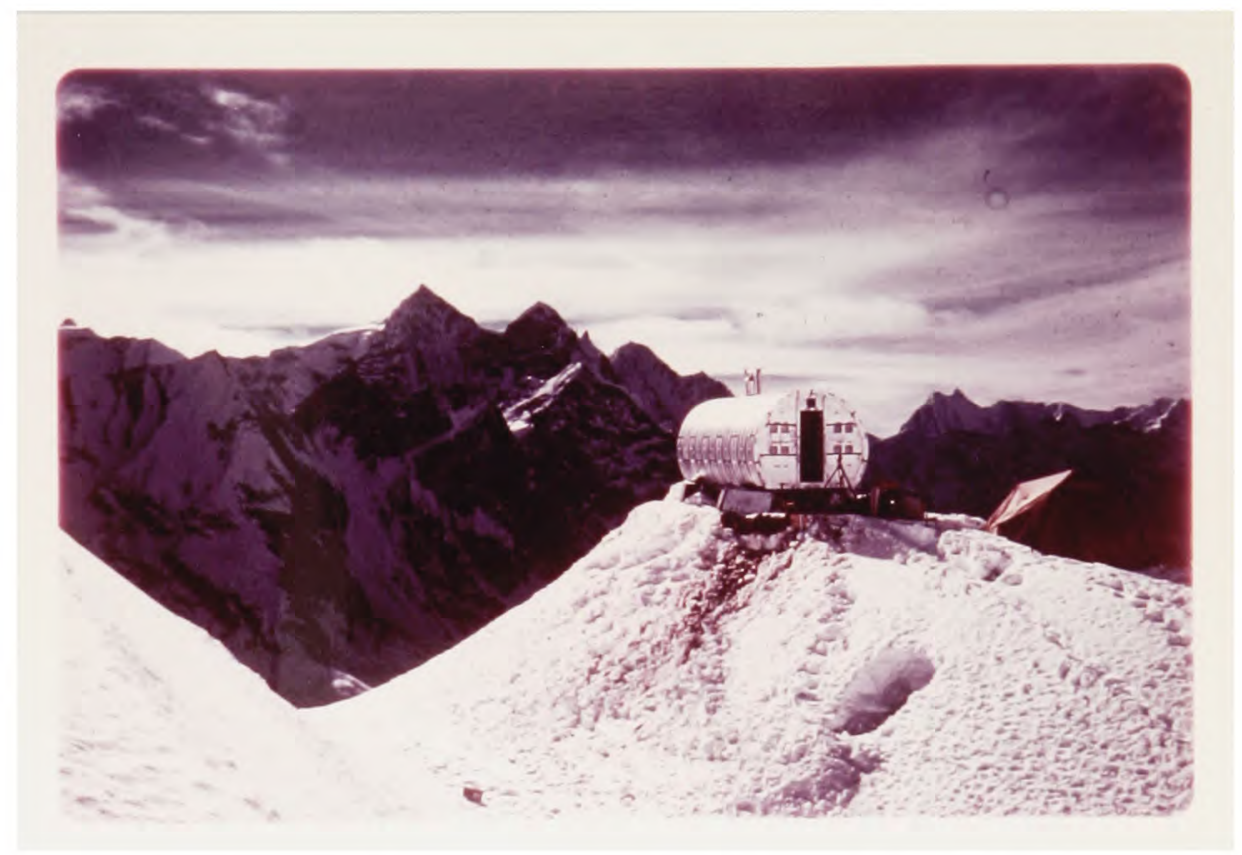

FIG. 1.1. The "Silver Hut", the main physiological station of the 1960/61 Iimalayan Scientific and ountaineering expedition. Altitude $5,800 \mathrm{~m}(19,000 \mathrm{ft})$. 


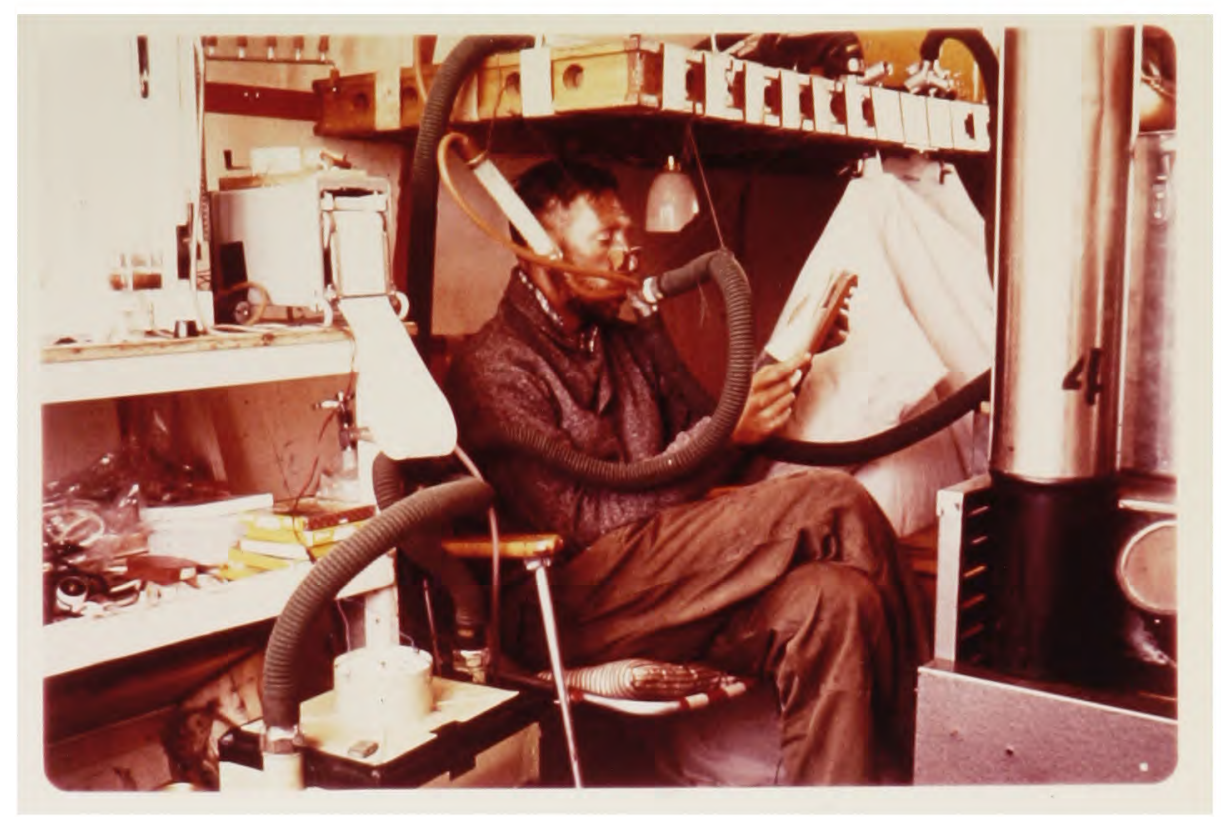

FIG. 1.2. Silver Hut interior, looking towards domestic end. Inhalation experiment in progress, subject Dr. John irest.

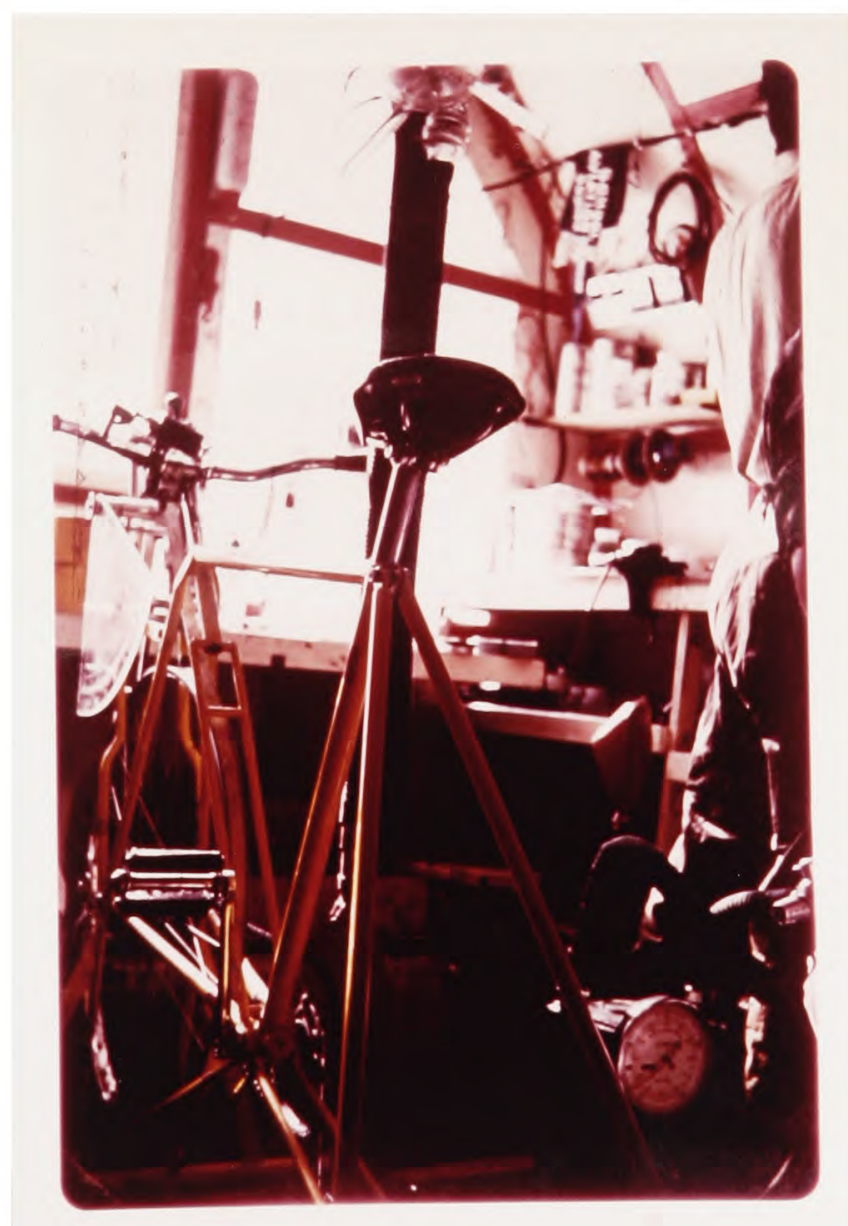

FIG. 1.3. Silver Hut interior, laboratory end with portable bicycle ergometer. 
team was led by Dr. S. Lahiri. The team consisted of Dr. S. Lahiri, Mr. Bhatacharia M. Sc who unfortunately could not acclimatise and left the expedition half way through, and the author. Our objective was to study the differences between ourselves, lowlanders acclimatised to altitude, and Sherpas, the local native residents.

The Sherpas are a tribe of Tibetan origin settled on the Southern slopes of the divide range of the Eastern Himalayas. They are now subdivided into groups according to location. The Khumbu, or highland Sherpas are usually regarded as the "true Sherpas" and the high altitude porters and climbers made famous through mountaineering expeditions are mostly drawn from them either direct or from Darjeeling where many have emigrated. It has long been realised by climbers that Sherpas are physically much more efficient at altitude than even the fittest and best acclimatised lowlander. For instance, we noticed on the first expedition that at $19,000 \mathrm{ft}$ at a steady gradient, a we11-acclimatised lowlander kept up comfortably with a Sherpa only if the latter were carrying a $60 \mathrm{lb}$ load. But previously the physiological basis for this difference had been studied hardly at al1.

Our physiological camp in this expedition was at an altitude of $16,000 \mathrm{ft}(4,800 \mathrm{~m})$ on the divide ridge between the Dudh Kos $i$ and Inuku Kola vallies. It was a tented camp (see photograph). A similar programme to that of the first expedition was carried out. A list of papers published is given in the appendix to this chapter. The programme included inhalation experiments at rest, and observations on exercise, comparing ourselves -- lowlanders -- with the Sherpa highlanders. 


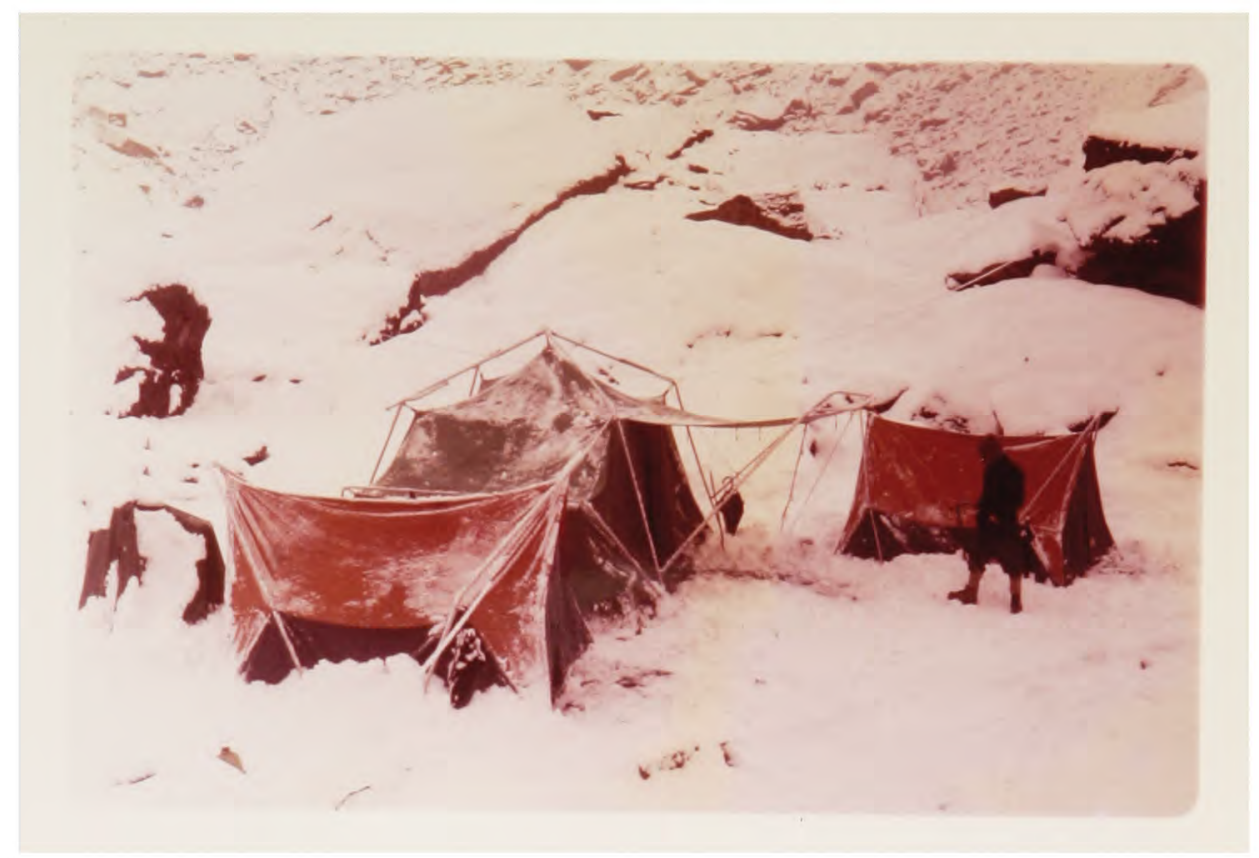

FIG. 1.4. Physiological camp, Lung Samba, 1964 expedition. Laboratory/ness tent in center, sleeping tents alons-side. Altitude 4,880m (16,000 ft).

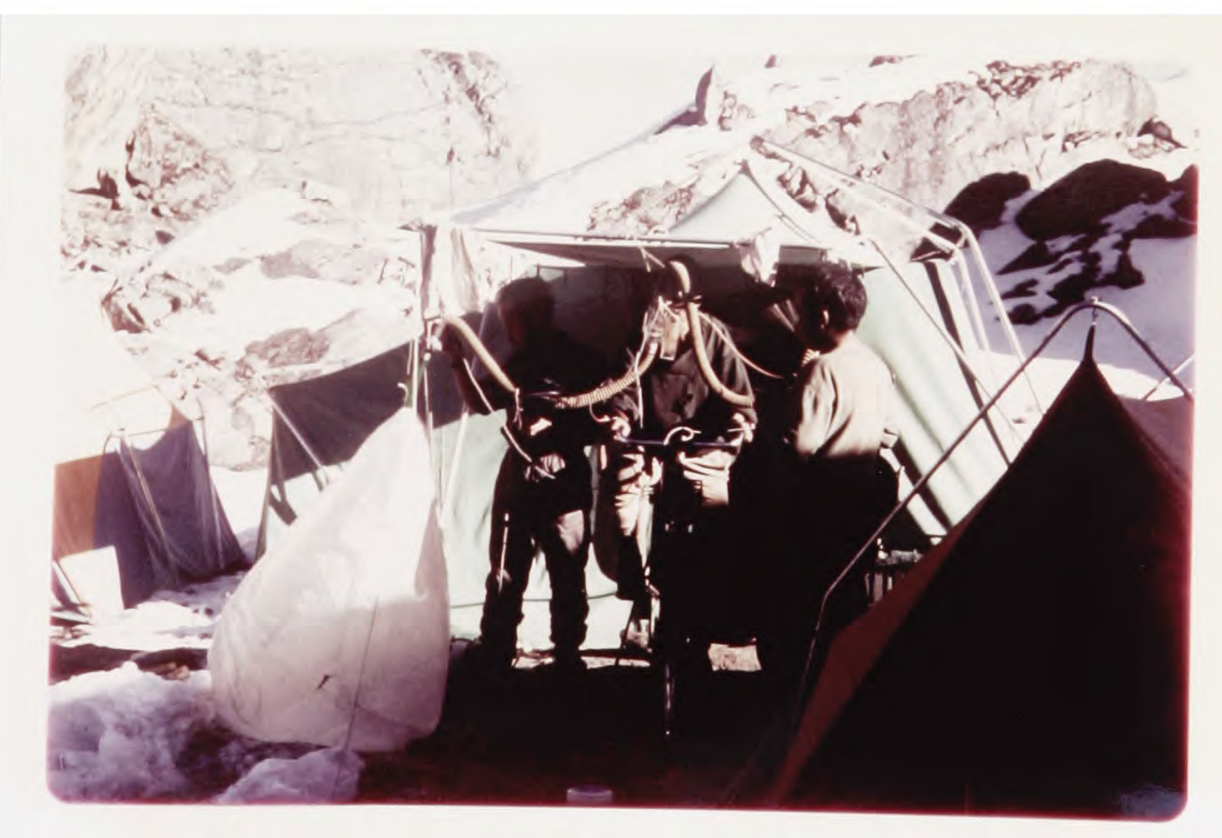

FIG. 1.5. Dr. Irahiri runing an exercise experimont on a Sherpa subject outside the laboratory tent. 


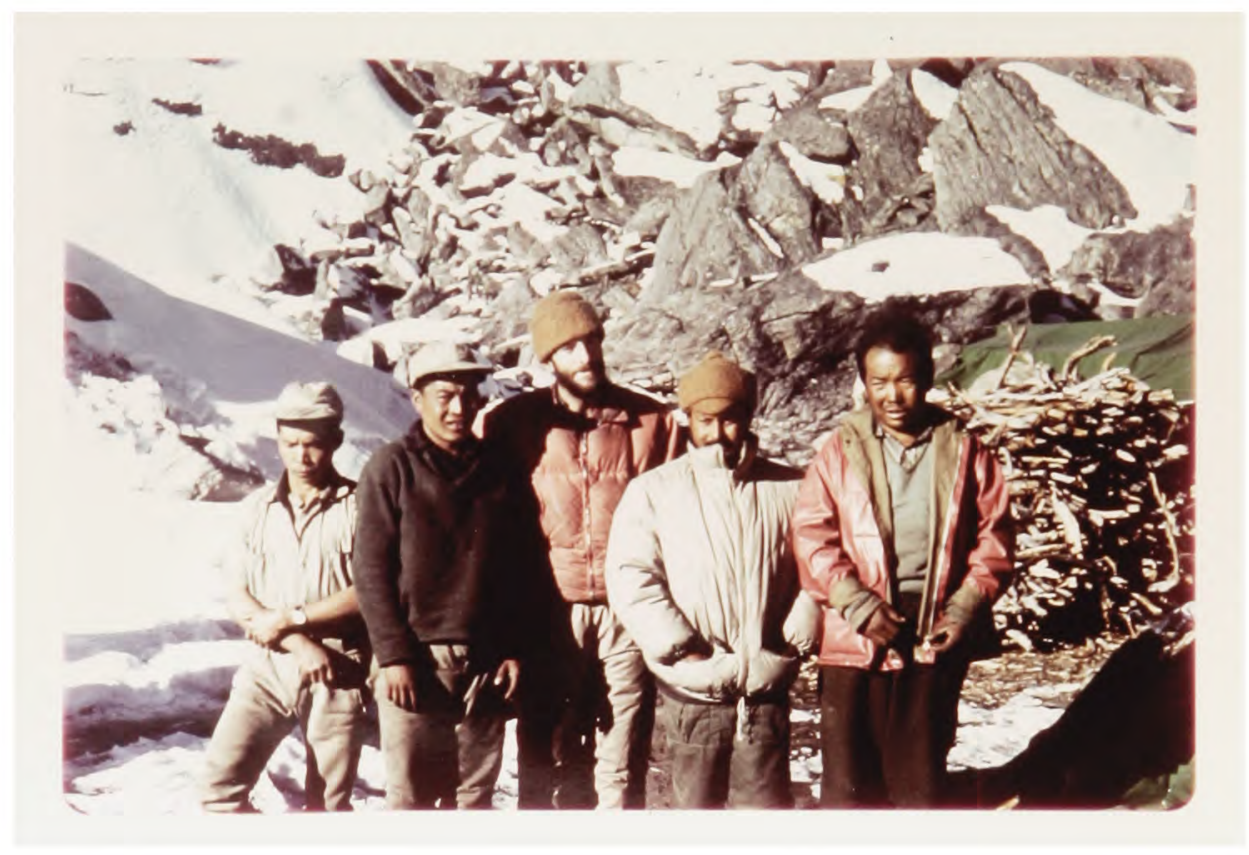

FIG. 1.6. The physiology team 1964 expedition at Lung Samba. It. to Rt., Sherpas Penury, IJakba tsering, the author, Dr. Lahiri, and Shorpa Hakba llorbu. 
The work was carried out at this one altitude over a period of two months, October to December 1964.

After the expedition one of our Sherpa subjects was studied at sea level at Calcutta and Vellore.

In March 1968 I was able to carry out some further high altitude studies in the Peruvian Andes at Cerro de Pasco $(14,500 \mathrm{ft}, 4,300 \mathrm{~m})$ with Dr. Soren C. Sorensen while we were in Dr. J. W. Severinghaus's laboratory in the Cardiovascular Research Institute, University of California, San Francisco. These studies were mainly concerned with cerebral metabolism in men native to high altitude. The study included measurement of cerebrospinal fluid $\mathrm{pH}, \mathrm{CO}_{2}$ and cerebral $\mathrm{A}-\mathrm{Vo}_{2}$ differences. Preliminary results from this study are added to those of the 1964 expedition in the chapter on acid base regulation (Chapter 6). 


\section{REFERENCES}

\section{Chapter I}

Bert, P. (1878). La Pression Barometrique, Reserches de Physiologie. Paris: Masson. (Translated into English bvM. A. Hitchcock and F. A. Hitchcock (1943). Columbus, Ohio: College Book Company.)

Cormack, K. S., D. J. C. Cunningham and J. B. L. Gee (1957). The effect of carbon dioxide in the respiratory response to want of oxygen in man. Quart. J. Exp. Physio1. 42, 303-314.

Douglas, C. G. and J. S. Haldane (1909). The regulation of norma 1 breathing. J. Physio1. 38, 420-440.

Douglas, C. G., J. S. Haldane, Y. Henderson and E. S. Schneider (1913). Physiological observations made on Pike's Peak, Colorado, with special reference to adaptation to low barometric pressures. Phil. Trans. Roy. Soc. London, Ser. B 203, 185-318.

Fitzgerald, M. P. (1913). The changes in the breathing and the blood at various high altitudes. Phi 1. Trans. Roy. Soc. London, Ser. B $203,351-371$.

Gray, J. S. (1950). Pulmonary Ventilation and Its Physiological Regulation. Springfield, I11 ińois: Thomas, pp. 29-46.

Haldane, J. S. and J. G. Priestly (1905). The regulation of lung ventilation. J. Physiol. 32, 225-266.

Heymans, J. F. and C. Heymans (1927). Sur les modifications directes et sur la regulation réflexe de l'activité du centre respiratoire de la tête isolée du chien. Arch. Intern. Pharmacodyn. 33, 272-370.

Hi 1 lary, E. and D. Doig (1962). High in the Thin Cold Air. New York: Doubleday and Co. Inc.

Jourdanet, D. (1861). Les Altitudes de l'Amerique Tropicale Comparées au Niveau des Mers au Point de Vue de la Constitution Medicale. Paris: Bajlliere.

Jacobs, M. H. (1920). To what extent are the physiological effects of carbon dioxide due to hydrogen ions? Am. J. Physiol. 5, 321-331. 
Kellogg, R. H. (1967). Altitude acclimatization a historical introduction emphasizing the regulation breathing. Fed. Proc. (in press).

Lloyd, B. B., M. G. M. Jukes and D. J. C. Cunningham (1958). The relationship between alveolar oxygen pressure and the respiratory response to carbon dioxide in man. Quart. J. Exp. Physio1. 43, 214-227.

Miescher-Rush, F. (1885). Bemerkungen zur Lehre von den Atembewegungen. Arch. Anat. u. Physio1. (Leipzig) 6, 355-380.

Mosso, A. (1898). Life of Man on the High Alps. (English translation from the Italian) London: T. Fisher Unwin.

Nielsen, M. and H. Smith (1952). Studies on the regulation of respiration in acute hypoxia. Acta. Physiol. Scand. 24, 293-313.

Perkins, J. F. (1964). Historical development of respiratory physiology: in Handbook of Physiology, Section 3: Respiration. Washington, D. C.: Am. Physiol. Soc., vol. 1, p. 2.

Pfluger, E. (1868). Ueber die Ursache der Atembewegungen, sowie der Dyspnoë und Apnoë. Arch. Ges. Physio1. 1, 61-106.

Walter, F. (1877). Unterauchungen üher die Winkung de Saüren auf den thierischen organismus. Arch. f. Exper. Patho1. 8, 148-178.

Ward, R. D. (1908). Alveolar air on Monte Rosa. J. Physio1. (London) $37,378-389$.

Winterstine, H. (1956). Chemical control of pulmonary ventilation III. The "reaction theory" of respiratory control. New Engl. J. Med. $255,331-337$. 


\section{APPENDIX TO CHAPTER I}

Bibliography of the 1960-61 Himalayan Scientific and Mountaineering Expedition. In order of publication.

1. Pugh, L. G. C.E. (1961). Science in the Himalaya. Nature 191, 429-430,

2. Pugh, L. G. C.E. (1962). Physiological and medical aspects of the Himalayan Scientific and Mountaineering Expedition 1960-61. Brit. Med. J. i i $621-627$.

3. West, J. B., S. Lahiri, M. B. Gill, J. S. Milledge, L. G. C. E. Pugh, and M. P. Ward (1962). Arterial oxygen saturation during exercise at high altitude. J.App1. Physio1. 17;617-621.

4. Gill, M. B., J. S. Milledge, L. G. C. E. Pugh, and J. B. West (1962). Alveolar gas composition at 21,000 to $25,700 \mathrm{ft}$. J. Physiol. 163, 373-377.

5. West, J. B. (1962). Pulmonary diffusion at high altitude. J. App1. Physio1. 17, 421-426.

6. Nevison, T. O., J. E. Roberts, W. W. Lackey, R. G. Scherman, and K. H. Averil1 (1962). Himalayan Scientific and Mountaineering Expedition 1960-61. 1. USAF high altitude physiological studies. Lovelace Foundation, Albuquerque, New Mexico and School of Aerospace Medicine, Brooks Air Force Base, Texas.

7. Milledge, J. S. (1963). Electrocardiographic changes at high altitude. Brit. Heart J. 25, 291-298.

8. Milledge, J. S. (1963). Respiratory regulation at $19,000 \mathrm{ft} .(5,700 \mathrm{~m}$. in: The Regulation of Human Respiration Edited by D.J.C. Cunningham and B.B. Lloyd, Blackwe 11, Oxford. p397-407.

9. Miche1 C.C. and J.S. Milledge,(1963). Respiratory regulation in man during acclimatization to high altitude. J. Physiol. 168, 613-643.

13. Pugh, L.G.C.E. (1963). Tolerance to extreame cold in a Nepalese pilgrim. J. Appl. Physio1. 18, 1234-1238.

11. Pugh, L.G.C.E.(1964). B lood volume and haemoglobin concentration at altitudes above $18,000 \mathrm{ft} .(5,500 \mathrm{~m})$. J. Physiol. 170, 344-354. 
12. Pugh, L.G.C.E., M.B. Gi11, S. Lahiri, J.S. Milledge, M.P. Ward and J.B.West, $(1964)$. Muscular exercise at great altitudes.

J. App 1. Physio1. 19, $431-440$.

13. Pugh, L.G.C.E. (1964). Cardiac output in muscular exercise at 5,800m. (19,000 ft.). J. App 1. Physiol. 19, 441-447.

14. Gi 11,M.B., E.C.Poulton, A.Carpenter, M.M.Woodhead, M.H.P.Gregory. (1964). Falling efficiency at sorting cards during Acclimatization at $19,000 \mathrm{ft}$. Nature 203,436

15. Gi11, M.B., and L.G.C.E.Pugh, (1964). Basal metabolism and respiration in men living at $5,800 \mathrm{~m}(19,000 \mathrm{ft}$.$) . J. App 1. Physio1. 19, 949-954.$

Bibliography of the Second Schoolhouse Expedition, 1964. In order of publication.

1. Lahiri, S. and J.S.Milledge, (1964) Himalayian schoolhouse expedition: the physiological program. The Guardian, Manchester, Dec 12th. pp 4-5.

2. Lahiri, S. and J.S.Milledge, (1965). Sherpa physiology. Nature 207, 610-612.

3. Lahiri, S. and J.S.Mi1ledge, (1966). Muscular exercise in the Himalayan high altitude residents. Fed. Proc. 25, 1392-1396.

4. Milledge, J.S. and S. Lahiri, (1967). Respiratory control in lowlanders and sherpa highlanders at altitude. Resp. Physiol. 2, 310-322.

5. Lahiri, S. and J.S.Milledge, (1967). Acid-base in Sherpa altitude residents and lowlanders at 4,880m. Resp. Physiol. 2, 323-334.

6. Lahiri, S. and J.S.Milledge, (1968). Relative respiratory insensitivity of Himalayan Sherpa altitude residents to hypoxia at $4,880 \mathrm{~m}$ and at sea leve1. in: Arterial Chemorecptors. Edited by R.W. Torrance. B lackwe 11, oxford. p387-391.

7. Lahiri, S.,J.S.Milledge, H.P.Chattopadhyay, A.K.Battacharya, and A.K.Sinha. (1967). Respiration and heart rate of Sherpa highlanders during exercise. J. App1. Physio1. 23, 545-554. 


\author{
C H A P T ER I I \\ CHANGES IN VENTILATORY RESPONSE TO $\mathrm{CO}_{2}$ AND $\mathrm{O}_{2}$ \\ ON ACCLIMATIZATION TO HIGH ALTITUDE
}

INTRODUCTI ON

This project followed directly from the work of the oxford School on the chemical control of respiration (Chapter I). The aim was to study quantitatively the changes in the ventilatory response to $\mathrm{CO}_{2}$ and hypoxia in a group of subjects, normally resident at low altitude, after sojourn at a higher altitude and for a longer time than is usua 1 in such studies.

The 1960-61 Himalayan Scientific and Mountaineering Expedition provided the opportunity for the project (Chapter I).

\title{
EXPERIMENTS
}

In the summer of 1960 experiments were carried out at oxford on members of the expedition who would serve as subjects at a1titude. The altitude experiments were carried out in two series, one near the beginning and one near the end of the four month' sorjourn at 5,800 $\mathrm{m}$. After the expedition two experiments were carried out in a low pressure chamber in order to determine the effect of reduced air density and viscosity alone on the ventilatory response to $\mathrm{CO}_{2}$. 
METHOD

Subjects

There were four principal subjects whose physical characteristics are shown in Table 2. 1.

\begin{tabular}{|c|c|c|c|}
\hline Subject & $\begin{array}{c}\text { Age } \\
\text { Yr }\end{array}$ & $\begin{array}{c}\text { Height } \\
\mathrm{cm}\end{array}$ & $\begin{array}{c}\text { Weight } \\
\mathrm{Kg}\end{array}$ \\
\hline \hline M B G & 23 & 180 & 64.4 \\
\hline J S M & 30 & 175 & 59.9 \\
\hline M P W & 35 & 178 & 66.7 \\
\hline J B W & 32 & 183 & 64.0 \\
\hline
\end{tabular}

Table 2. 1. Physical characteristics of subjects:

Weight declined during stay at altitude. Weight given is that recorded at about the mid point of stay, between the two series of experiments .

The subjects were all members of the scientific team of the expedition, most of them being climbers as we11. Two of the subjects, J.S.M. and M.B.G., had been in Nepal for $31 / 2$ months before the experiments were started most of the time being spent at altitudes above $15,000 \mathrm{ft}$ leading an active life while preparing the various camps and huts for the winter. The other two subjects, J.B.W. and M.P.W., arrived in the field later, having had about one month at intermediate altitudes before experiments on them started. All four subjects acclimatized well as judged by general climbing criteria, and al1 remained fit during their stay at altitude except for a steady loss 
of weight of from $0.5 \mathrm{~kg}$ to $1.5 \mathrm{Kg}$ per week which was more pronounced towards the end of the winter. Exercise was taken almost every day in the form of skiing and occasional climbing excursions.

\section{Apparatus}

Fig. 2.1. The apparatus for use in the field was adapted from that described by Cunningham, Cormack, O'Riordan, Jukes and Lloyd (1957), Douglas bags being substituted for rotameters. The subject inhaled through low-resistance valves a gas mixture from a large capacity Douglas bag (capacity 500 litres). The gas was humidified by passing it through a biscuit tin containing hot water. The exhaled gas passed through a gas meter to a second Douglas bag in which it was collected. The gas meter carried a simple electronic device giving a signal at every 5 litres, which activated a pen recorder also carrying a time trace. From the valve a Rahn-0tis end tidal gas sampler took gas which was drawn over a rack of sampling tubes and through a $\mathrm{CO}_{2}$ meter by a Monaldi suction pump. The $\mathrm{CO}_{2}$ meter was a kinetic gas analyser made and described by Wright (1959).

\section{Gas mixtures}

Gas mixtures were made up by volume before and during the experiments from room air and cylinder $\mathrm{CO}_{2}$ and $\mathrm{O}_{2}$. For the first five experiments (at altitude) only three mixtures were used, later a fourth was added. These mixtures were made up so as to have a $\mathrm{PcO}_{2}$ between 15 and $20 \mathrm{~mm} \mathrm{Hg}$ and $\mathrm{PO}_{2}$ of approximately $54,75,90$ and $180 \mathrm{~mm} \mathrm{Hg}$. In the last four experiments the high-oxygen mixture was pure oxygen, $\mathrm{PO}_{2} 300$. The mixture with the lowest $\mathrm{PO}_{2}$ was made by collecting expired air from the 
subject before the start of the experiment, and arranging for half the volume to pass over soda-lime. Thus a mixture having the desired $\mathrm{Po}_{2}$ was obtained without the use of large quantities of cylinder nitrogen, which would have been impracticable.

\section{Procedure}

Experiments were all conducted in the morning except for two in the second series during a time of great pressure of work on other programmes. In view of the steady loss of weight that all the subjects suffered it was not considered justifiable to insist on the subjects being in a fasting state, but no experiments were started until at least 2 hours after a meal.

The subject was seated on a bunk and made comfortable with sleeping bags and encouraged to read. After a steady state had been reached with the subject breathing room air, as indicated by a steady reading on the $\mathrm{CO}_{2}$ meter, usually after 7-10 minutes on the valves, a sample of alveolar air was taken and the first mixture switched on. The subject breathed this until he emptied the Douglas bag. During this time, when the $\mathrm{CO}_{2}$ meter indicated a steady state, an alveolar sample was taken. After the bag was exhausted, the two Douglas bags were reversed so that the subject inhaled his expirate. Thus a mixture having a higher $\mathrm{PCO}_{2}$ and slightly lower $\mathrm{Po}_{2}$ was then inhaled, resulting in a higher ventilation. This process was continued until a ventilation of about $501 \mathrm{itres} / \mathrm{min}$. was reached and then repeated starting with a different gas mixture. Usually 3-4 runs were necessary. The process could be shortened by adding a small quantity of $\mathrm{CO}_{2}$ to the first exhalate. Experiments 
started with the lowest oxygen mixture proceeding in order to the highest. The experiments lasted about $1 \frac{1 / 2}{2}$ to 2 hours. The gas samples were analysed later in Lloyd-Haldane apparatus (Lloyd 1958).

\section{Sea level experiments}

The sea-level experiments were similar to those carried out at altitude, though here the subject was seated in a dentist's chair which could be adjusted to suit his comfort. For all sea level determinations on M.B.G., and for experiment 3 on J.S.M., the apparatus was the same as that used at high altitude. In other sea level experiments the unmodified methods of Cunningham et al (1957) were embloyed, gas mixtures being made up from rotameters, etc.

\section{Results}

Ten experiments were carried out at sea level and sixteen at altitude. The unprocessed data of these experiments is given in Table 2. 2 (a) and (b). The results were first plotted on a $\dot{V} / \mathrm{PCO}_{2}$ graph as shown in Fig. 2. 2. The graphs for all experiments are shown in Fig. 2. 3. In this figure the sea level and altitude experiments are plotted together, the altitude plots being invariably to the left.

From Fig. 2. 3 it will be seen that:

1) The trend is towards a fan of isoxic $\mathrm{V} / \mathrm{PCO}_{2}$ lines radiating from a single point, $\mathrm{B}$, on the $\mathrm{PCO}_{2}$ axis, as shown by Lloyd, Jukes and Cunningham (1958). The assumption that this is so is basic to the use of the equation and the calculation of the parameters. For this reason points which are suspected of being below the $\mathrm{CO}_{2}$ threshold of Neilsen and Smith (1951) are neglected in this treatment. 


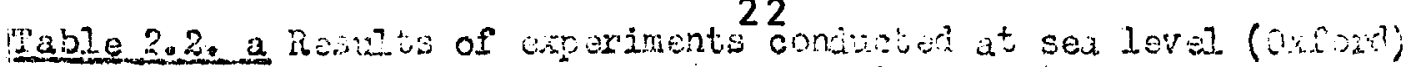
on four subjects used at altjturle. ventilation, litre per min, B.T.P.

Subject: J.S.M.

\begin{tabular}{|c|c|c|c|c|c|}
\hline Expt. & 1 & $2+1 / 2 / 00$ & Expt. & 3 & $30 / 7 / 60$ \\
\hline $01 / \mathrm{min}$ & $\begin{array}{r}\mathrm{P}_{\mathrm{B}} \mathrm{CO}_{2} \\
\mathrm{P}\end{array}$ & 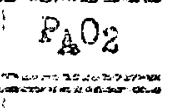 & " & $\mathrm{P}_{\mathrm{A}} \mathrm{CO}_{2}$ & $\mathrm{P}_{\mathrm{A}} \mathrm{O}_{2}$ \\
\hline 19.9 & 13.3 & 119.8 & 18.1 & 10.1 & 45.1 \\
\hline 18.0 & 42.4 & 60.0 & 20.0 & 40.2 & 64.2 \\
\hline 20.1 & 41.9 & 51.7 & 20.5 & 42.1 & 118.0 \\
\hline 22 & 42.0 & 41.3 & 50.2 & 42.5 & 43.2 \\
\hline 27.7 & 39.7 & 37.0 & 40.4 & 43.1 & $4 B .9$ \\
\hline 43.2 & 50.6 & 116.7 & 30.4 & 45.4 & 54.6 \\
\hline $46 . ?$ & 51.4 & (650) & $4 ? .5$ & 44.6 & $73 . ?$ \\
\hline 49.0 & 51.8 & $11 \%$ & $52 . i$ & 48.0 & 112,0 \\
\hline 48.9 & 49.2 & 66.5 & 51.0 & 49.0. & $(650)$ \\
\hline 89.0 & 47.2 & 53.0 & & & \\
\hline 45.5 & 45.8 & 42.5 & & & \\
\hline 12.3 & 15.6 & 30.5 & & & \\
\hline
\end{tabular}

Expt. $22 i / 7 / 60$

Expt. $40 / 8 / 60$

\begin{tabular}{|c|c|c|c|c|c|}
\hline f1/min & $P_{0,02}$ & $\mathrm{P}_{R_{2}} \mathrm{O}_{2}$ & Wimin & $\mathrm{S}_{\mathrm{B}} \mathrm{CO}_{2}$ & $P_{1} o_{2}$ \\
\hline 20.9 & 11.0 & 46.9 & 20.3 & 42.29 & 42.1 \\
\hline 18.6 & 11.2 & 65.3 & 18.0 & 42,8 & 6204 \\
\hline 20.1 & 83.0 & 110.9 & 23.2 & 4.3 .1 & 137.9 \\
\hline 45.5 & 42.4 & 4.5 .2 & 29.0 & 4.1 .17 & 39.0 \\
\hline 48.0 & 403 & 5101 & 40.0 & 15.7 & 13.4 \\
\hline 47.0 & 40.3 & 07.8 & 43.0 & 47.8 & 52. \\
\hline 57,0 & 50.4 & 121,2 & $4 A_{2}=5$ & 50.8 & 118.5 \\
\hline 45.0 & 43.8 & $(60)$ & 49.0 & 48.8 & $c i .8$ \\
\hline & & & 51.0 & 52.1 & $(650)$ \\
\hline
\end{tabular}


TdBIS 2 2 a contd

Sibiect: J.B.H

Sujject: isp:"

\begin{tabular}{|c|c|c|c|c|c|c|c|c|}
\hline Exps. & 1 & $\therefore, 1 / 60$ & $m_{2}+$ & 1 & $6 / 8,50$ & Sipto & 2 & $8 / 11 / 00$ \\
\hline 12.6 & $1 \%=1$ & 121.1 & 17. & 41.3 & 11.8 & 11,6 & 4205 & 121.1 \\
\hline 20.3 & 48.8 & 102.8 & 18.6 & 43.1 & 58.0 & 11.5 & 43.3 & $56 . \frac{1}{2}$ \\
\hline 31.4 & 37.2 & 107.5 & 18.3 & 42.8 & 121.5 & 15,7 & $42: 4$ & 45.0 \\
\hline 26.1 & 41.1 & 75.5 & 37.5 & $11_{0} 9$ & 53.7 & 00.0 & 52.4 & $=0.5$ \\
\hline 42,0 & 48.8 & 70.3 & 33.0 & 40.6 & 42.5 & 44.1 & 53.6 & $44 . ?$ \\
\hline 5.5 .3 & 50.6 & 73.0 & 43.2 & 49.7 & 53.0 & 50.1 & 53.4 & $54, ?$ \\
\hline $23_{0} \stackrel{1}{=}$ & 12.2 & 45.2 & 40.5 & 49.3 & 60.3 & 48.5 & 53.7 & 67.8 \\
\hline 41,3 & 45.3 & 2.5 .4 & 4.7 .6 & 52.6 & 121.2 & $\Delta \hat{S}_{8} 1$ & $5: 5$ & 79.2 \\
\hline 52,5 & $\Delta E_{3} 3$ & 43.9 & 46.7 & 5,1 & $(650)$ & 19.4 & 53.3 & $11 \tilde{1}$ \\
\hline 51.0 & 52.1 & 128.7 & & & & 12.1 & $5 \dot{i}=8$ & $(505)$ \\
\hline
\end{tabular}

يujeg: 1230 .

\begin{tabular}{|c|c|c|c|c|c|c|c|c|}
\hline int. & 1 & $1 \varepsilon / 7 / 00$ & Exp: & 2 & $21 / 7 / 63$ & $2 \operatorname{con}^{2}$ & 3 & $2: 2 / 60$ \\
\hline Jimin & $\mathrm{PCO}_{2}$ & $P_{1} C_{2}$ & Jinin & $p_{4}, 002$ & $P C_{n}$ & $\mathrm{n} / \mathrm{min}$ & $P_{4} \mathrm{CO}_{2}$ & $p_{2}$ \\
\hline 15.1 & 40.1 & 12500 & 2000 & 13.5 & 100.1 & 19.5 & 40.5 & 1500 \\
\hline 248 & 11.5 & $10 x_{0} 3$ & $3: 5$ & $4 i_{0} 1$ & 100.5 & 27.8 & $13 . ?$ & 40.6 \\
\hline 25.5 & 450 & 106. & 1200 & 47.8 & 102.1 & 50.0 & $4 A=5$ & 4.1 \\
\hline 37.5 & $10 . A$ & 96.7 & $3: 0$ & $4: .5$ & 75.2 & 28.5 & 13.3 & 75.5 \\
\hline 38.1 & 45.1 & 79.6 & 41,8 & 47.5 & 77.2 & $4 \%$ & 45.1 & 63.2 \\
\hline 43.7 & 47.7 & $3 \%, 8$ & 52.5 & $4 \therefore 3$ & 75.6 & 20.0 & 11,2 & 120.1 \\
\hline 55.7 & 18.0 & 85.2 & 2.25 & 40.2 & 45.4 & 30.8 & 4.4 .1 & 102.5 \\
\hline 21.5 & 63 & $5 \% .5$ & 41.7 & 45.6 & 450 & $1 \hat{3} .5$ & 1.7 .1 & 101.1 \\
\hline 19.0 & 16.0 & 65.1 & 30.0 & 12.0 & 43.1 & & & \\
\hline 53.0 & 15.6 & 000 & & & & & & \\
\hline
\end{tabular}




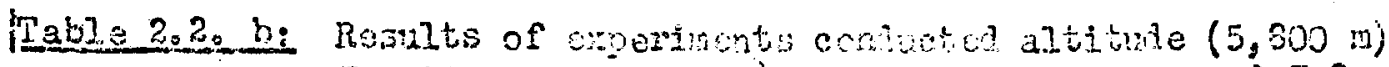

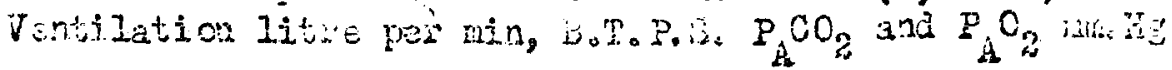

Subfect: To is.

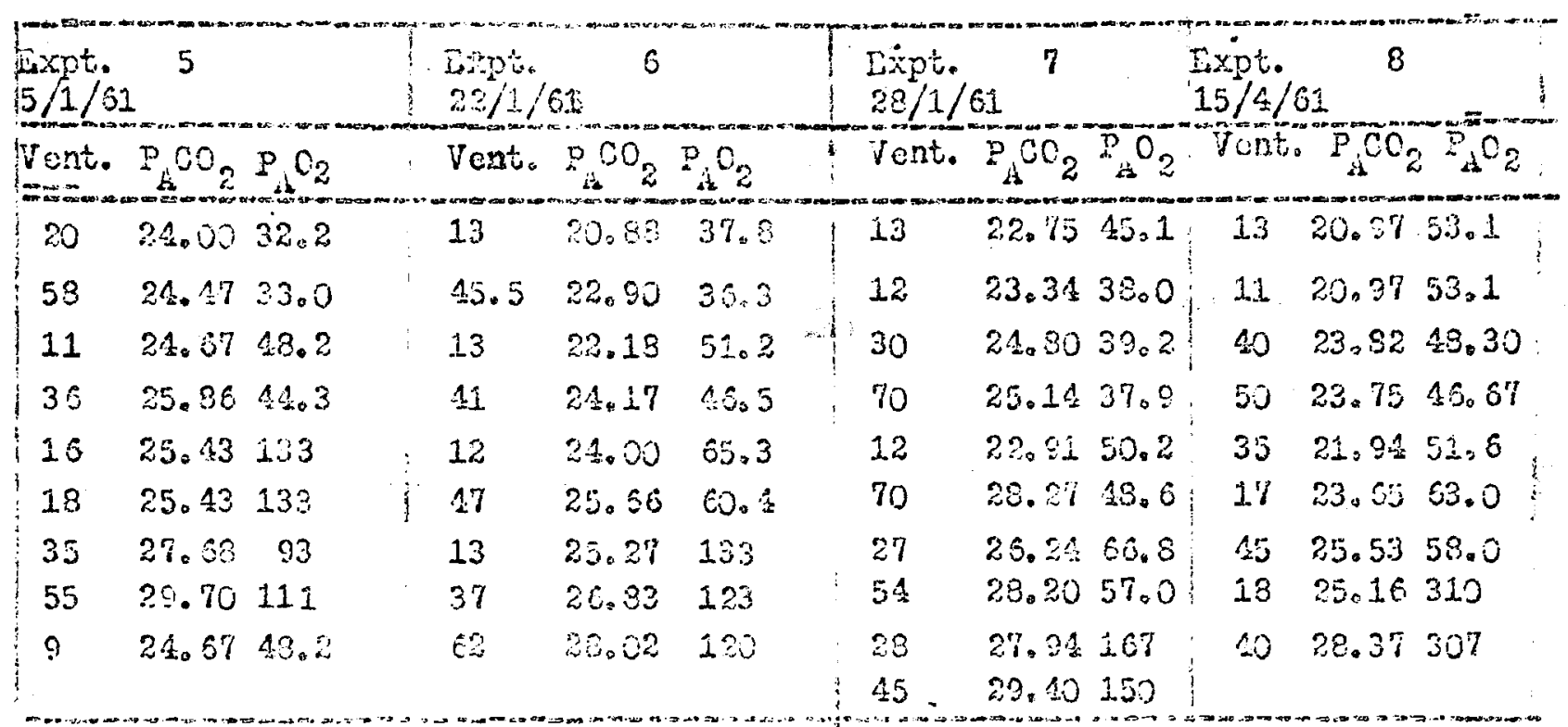

Groject: MoB

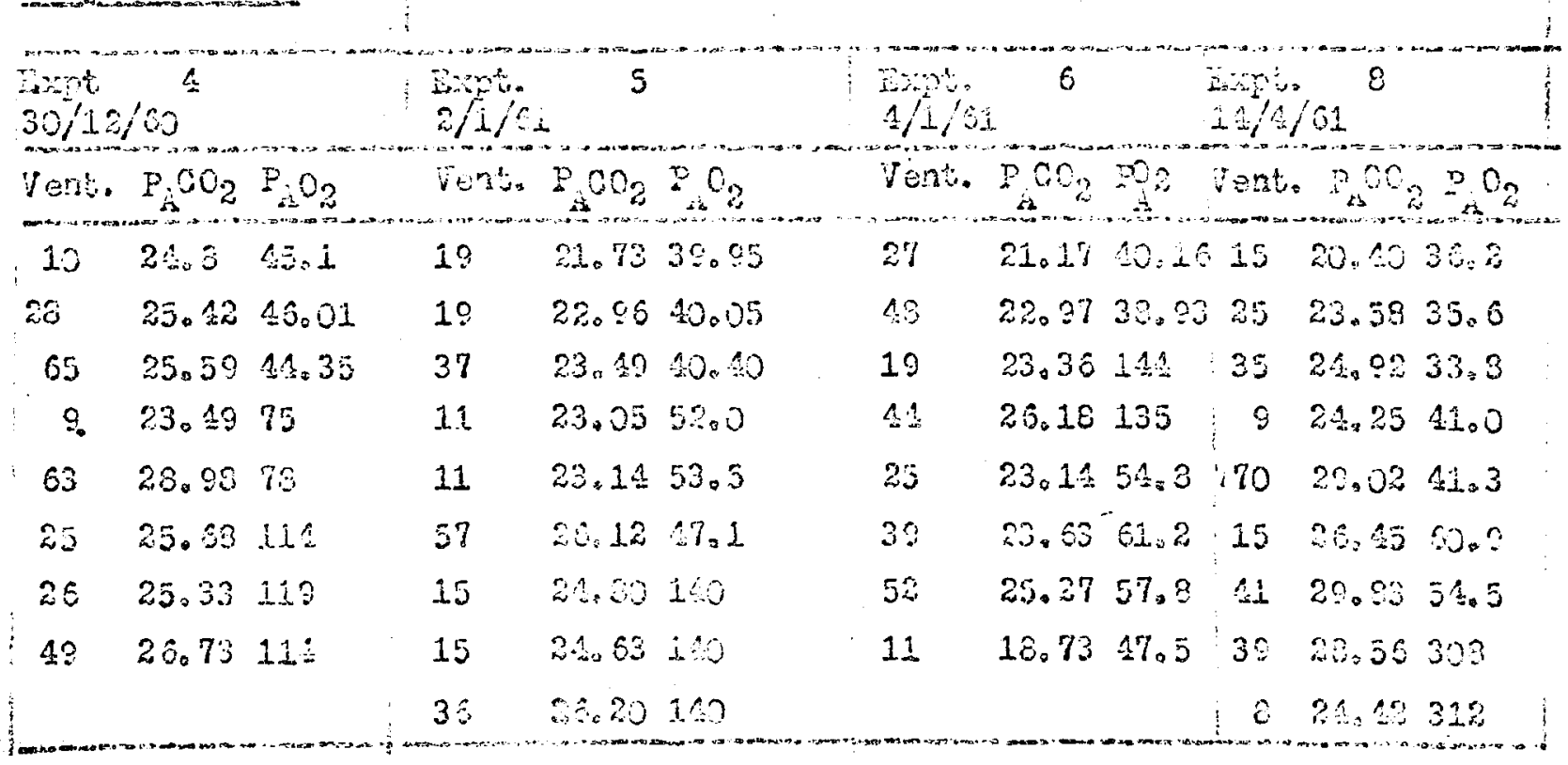


Toble 2.2.3. Conto

Suoject: H.P.W.

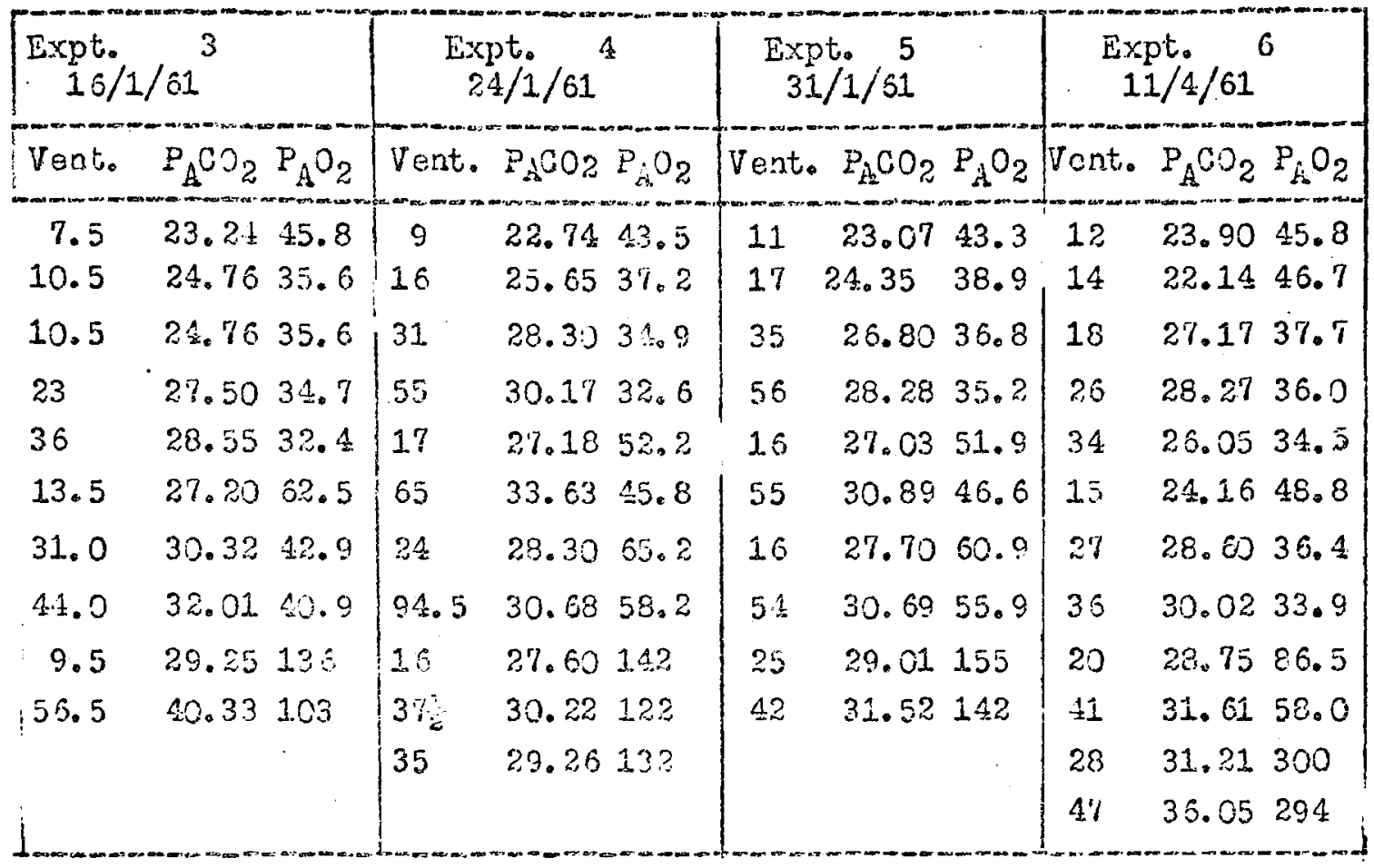

Subject: J.B. Hes:

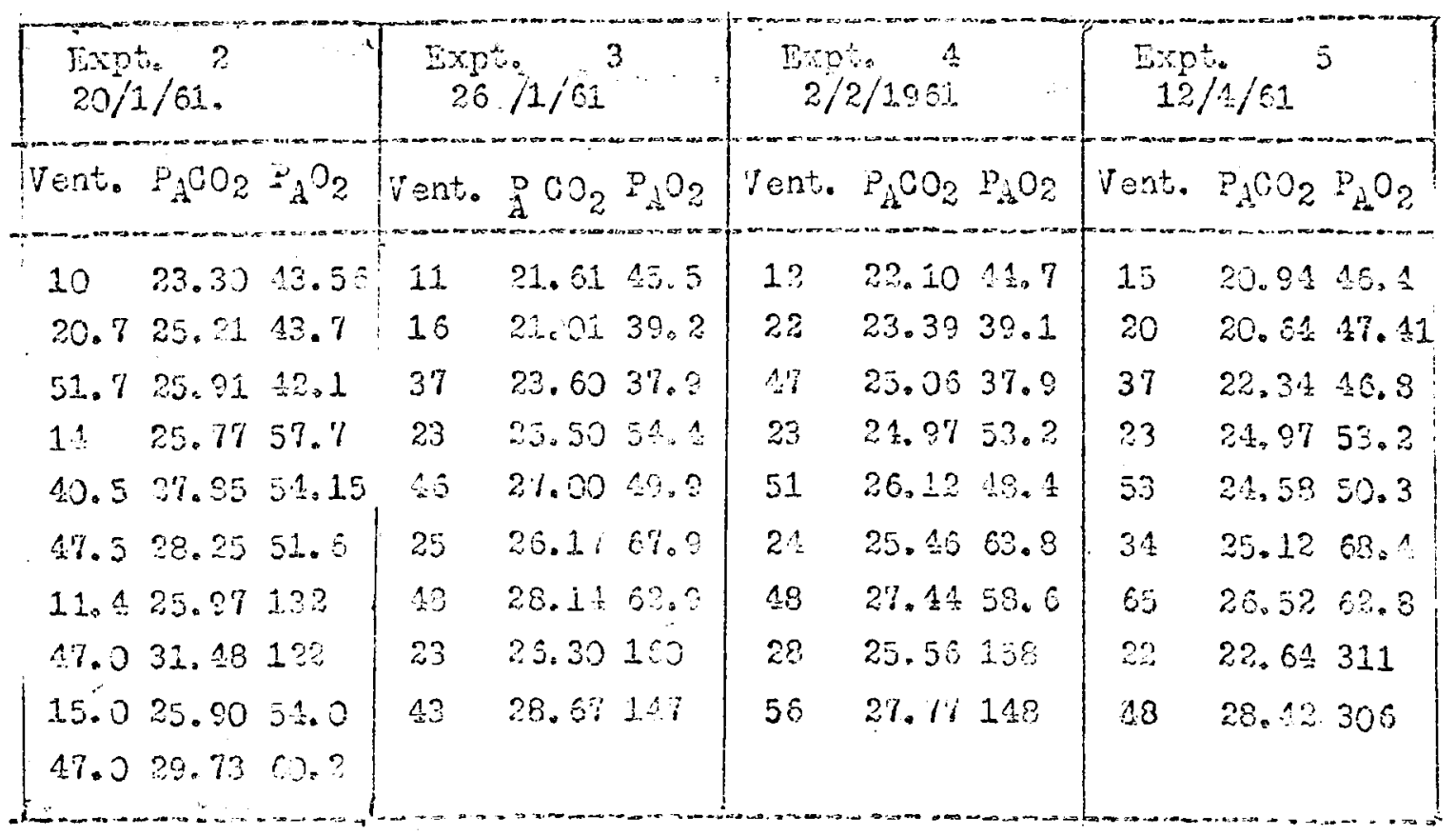



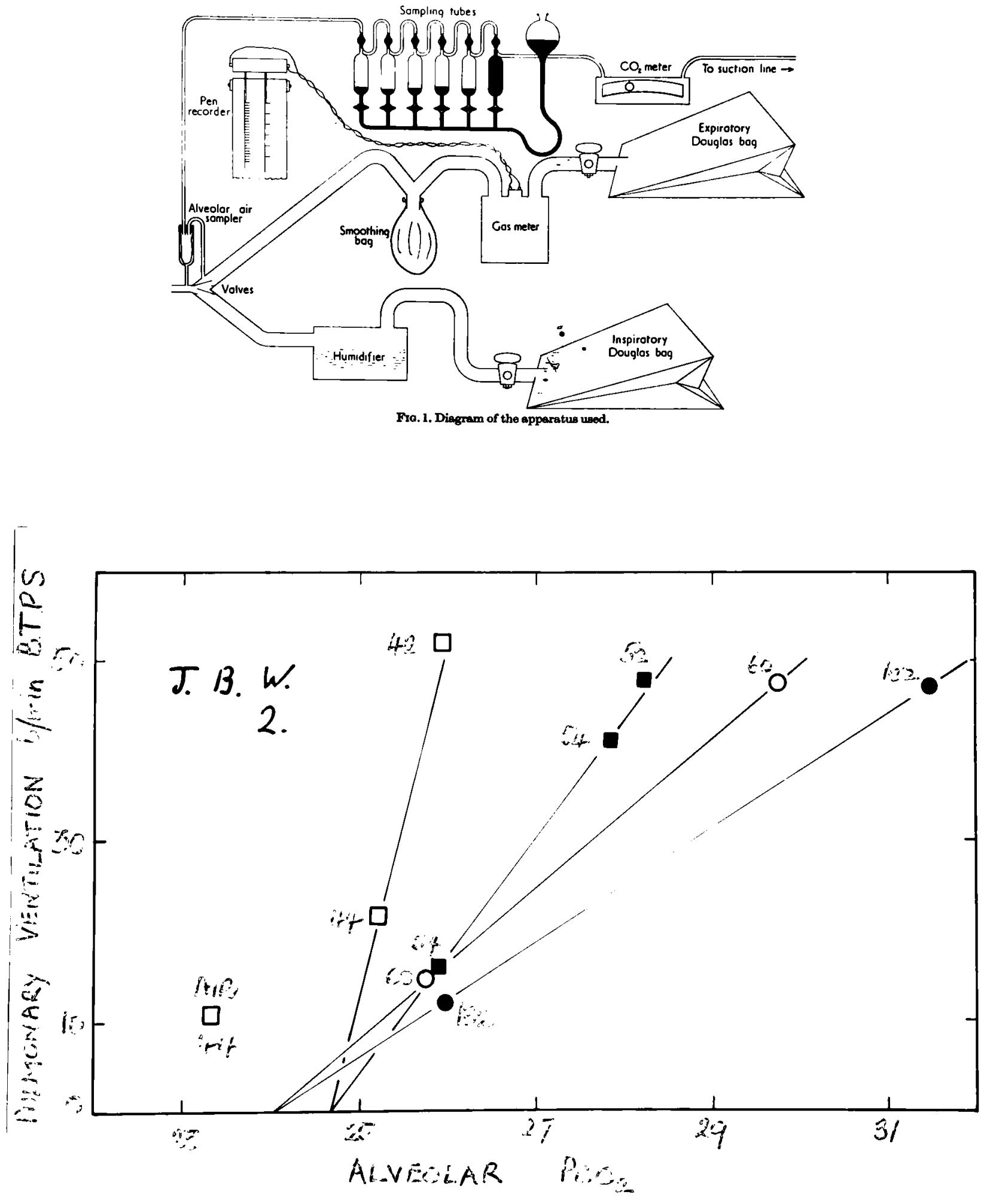

FIG. 2.2. The relation between pulmonary ventilation and alveolar $\mathrm{PCO}_{2}$ and $\mathrm{PQ}_{2}$, the results of one experiment at $5,800 \mathrm{~m}(19,000 \mathrm{ft})$. The figures against the points indicate the actual $\mathrm{PAO}_{2}$ values. Lines are drawn by eye through points of equal $\mathrm{PAO}_{2}$. Symbols as in Fig. 2.3. 


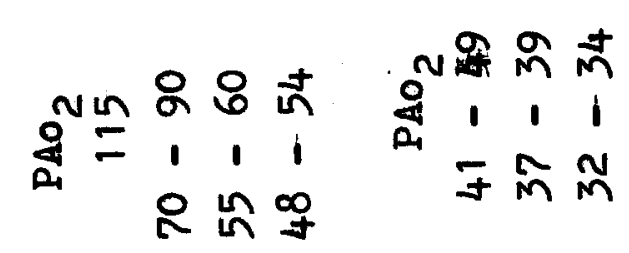

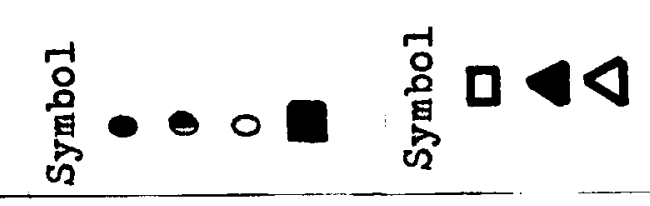

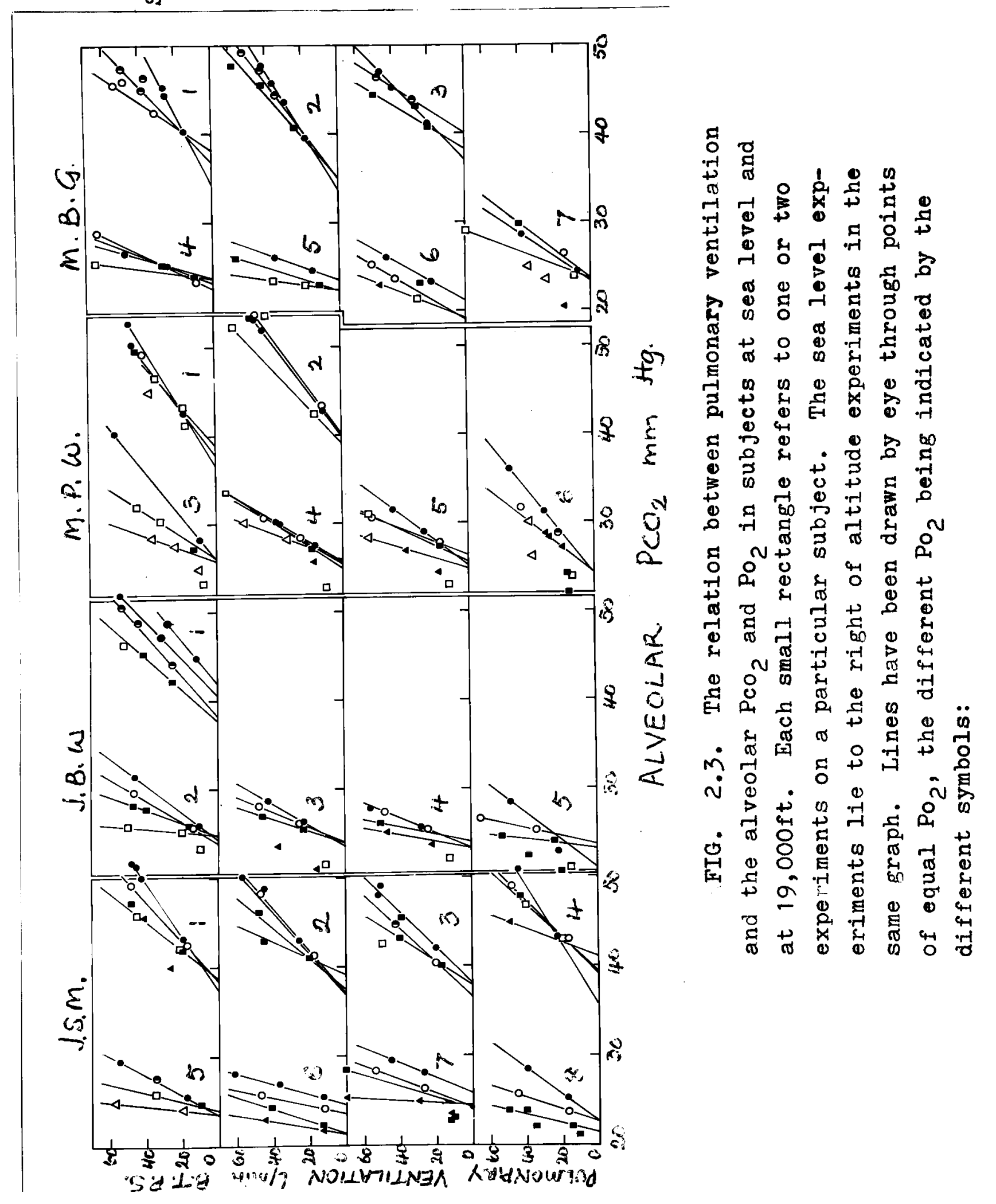


2) At altitude, $\mathrm{B}$, the intercept of the $\mathrm{V}-\mathrm{PCO}_{2}$ line, is much reduced, i.e., the fan is shifted to the left.

3) The slope of the high $\mathrm{PO}_{2}$ lines is much increased at altitude, i.e., the fan is 'folded up' from the right.

Calculation of the parameters $B, C, D$ and $A$

On the $\mathrm{V} / \mathrm{PCO}_{2}$ graph lines connecting points of equal $\mathrm{PO}_{2}$ are drawn by eye (Figs. 2. 2 and 2. 3). These give a number of values for B which when averaged give a mean B of first approximation. This value is then used to obtain by extrapolation a set of $\mathrm{PO}_{2}, \mathrm{PCO}_{2}$ values for a constant $\dot{V}$ arbitrarily selected to have a value near to the experimentally determined values at high $\dot{V}$. Equation (3) can be manipulated (Lloyd and Cunningham 1963) to give:

$$
\mathrm{PCO}_{2}=\frac{\dot{\mathrm{V}}}{\mathrm{D}}+\mathrm{B}-\left\{\frac{\dot{\mathrm{V} A}}{\mathrm{D} \mathrm{PO}_{2}-(C-A)}\right\}
$$

According to this equation, at constant $\dot{V}, \mathrm{PCO}_{2}$ should be a linear function of $1 / \mathrm{PO}_{2}-(C-A)$, if the appropriate value of $(C-A)$ is selected. This value of $(C-A)$ is then found by trial and error to give the most linear graph of $\mathrm{PCO}_{2}$ against $1 / \mathrm{PO}_{2}-(C-A)$. The straight line drawn through the points so obtained has a slope of $V A / D$ and an intercept on the $\mathrm{PCO}_{2}$ axis $\dot{V} / D+B$. As $B$ and $\dot{V}$ are known, $D, A$ and, from the final value of $(C-A), C$ can be calculated. In Fig. 2.4 the parameters of the experiment shown in Fig. 2. 2 are calculated in this manner. 


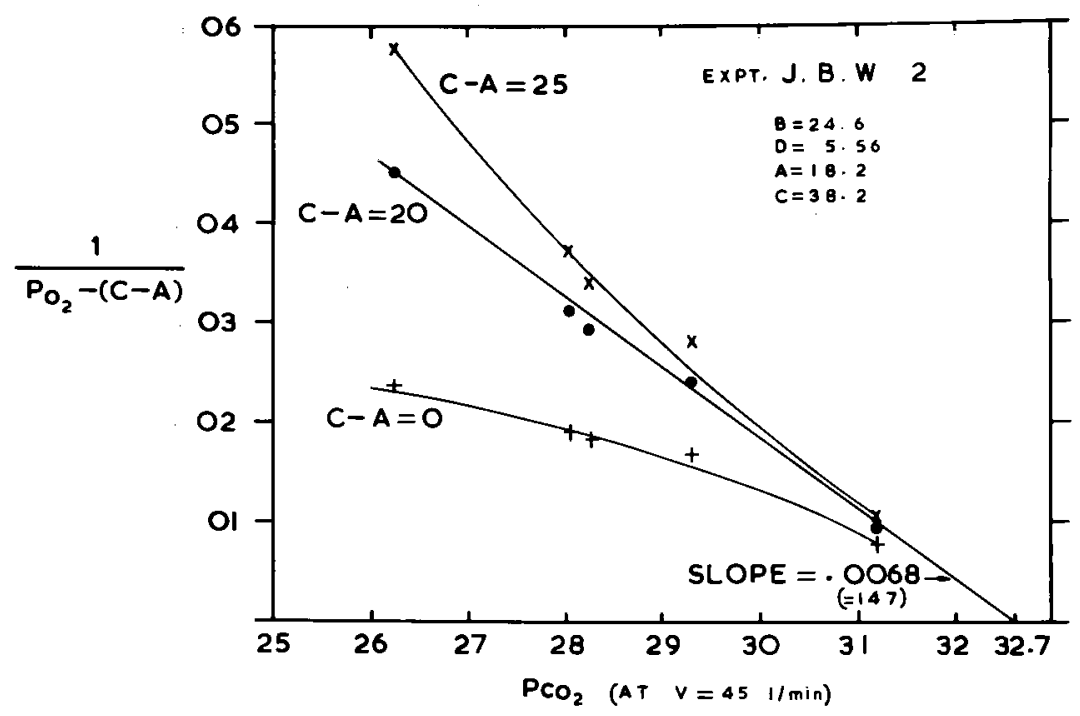

FIG. 2.4. Graph showing the method used to calculate the paramaters $D, A$ and $C$ of the equation relating $\dot{V}$ to $\mathrm{PO}_{2}$ and $\mathrm{PcO}_{2}$. The data is drawn from the experiment shown in fig 2.2. $1 / \mathrm{PO}_{2}-(\mathrm{C}-\mathrm{A})$ is plotted against $\mathrm{PCO}_{2}$ at constant $\dot{V}(45 \mathrm{l} / \mathrm{min})$. Three different values for $\mathrm{C}-\mathrm{A}$ were tried and the value $\mathrm{C}-\mathrm{A}=20$ was found to give the best fit. From this value, the slope of the line and the intercept on the $\mathrm{PcO}_{2}$ axis, the three paramaters can be calculated. (see text). 
Parameters B, D, C and A

The results of this calculation for al1 the experiments are given in Table 2. 3 and Fig. 2. 5. It will be seen that the reduction in $B$ is found in all subjects and there is very little scatter. The changes in B appear to be complete before the start of the first experimental series. The reduction is from a mean of 38.1 at sealeve 1 to 23.4 at altitude.

$D$ is seen to be approximately doubled from a mean of 3.5 to 7.3 . The values: for D for J.B.W. and M.P.W., who arrived later at altitude, show a progressive increase over the first series of experiments lasting about three weeks, from initial values of 5.6 and 3.3 to 7.8 and 6.8 in the last pair of experiments, which then approximate to the value of $D$ in the other two subjects who had been at 19,000 ft. about 2 months longer.

The values for $C$ show more scaiter but no definite trend. There seems to be no change in this parameter, while $A$ shows some increase in three out of four subjects. The calculation of these parameters is more susceptible to deviations in the subject's response from that predicted by the equation and consequently it is difficult to demonstrate small changes in their values.

\section{Alveolar point on air}

Measurements of the alveolar gas with the subject at rest breathing room air preceded two experiments on J.S.M. and a 11 experiments on J.B.W. and M.P.W. In every case the alveolar $\mathrm{PCO}_{2}$ was found to lie 2 to $4 \mathrm{~mm}$ below B. See Figs. 2. 2 and 2.3 . 
Lablí2.3 Results of calculated yestudets

$$
\begin{array}{llll}
B & \mathrm{Tm} \mathrm{Hg} \mathrm{PCO} & \text { C } & \mathrm{Hg}_{2} \mathrm{PO}_{2} \\
\text { D } & 1 / \mathrm{min} / \mathrm{mm} \mathrm{HC} \mathrm{PCO}_{2} & \text { A } & \mathrm{Hg} \mathrm{PO}_{2}
\end{array}
$$

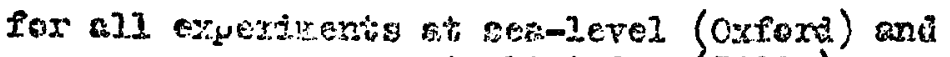
at altitude $(5800 \mathrm{ia})$.

SIA IEVUT

ALITIUDE

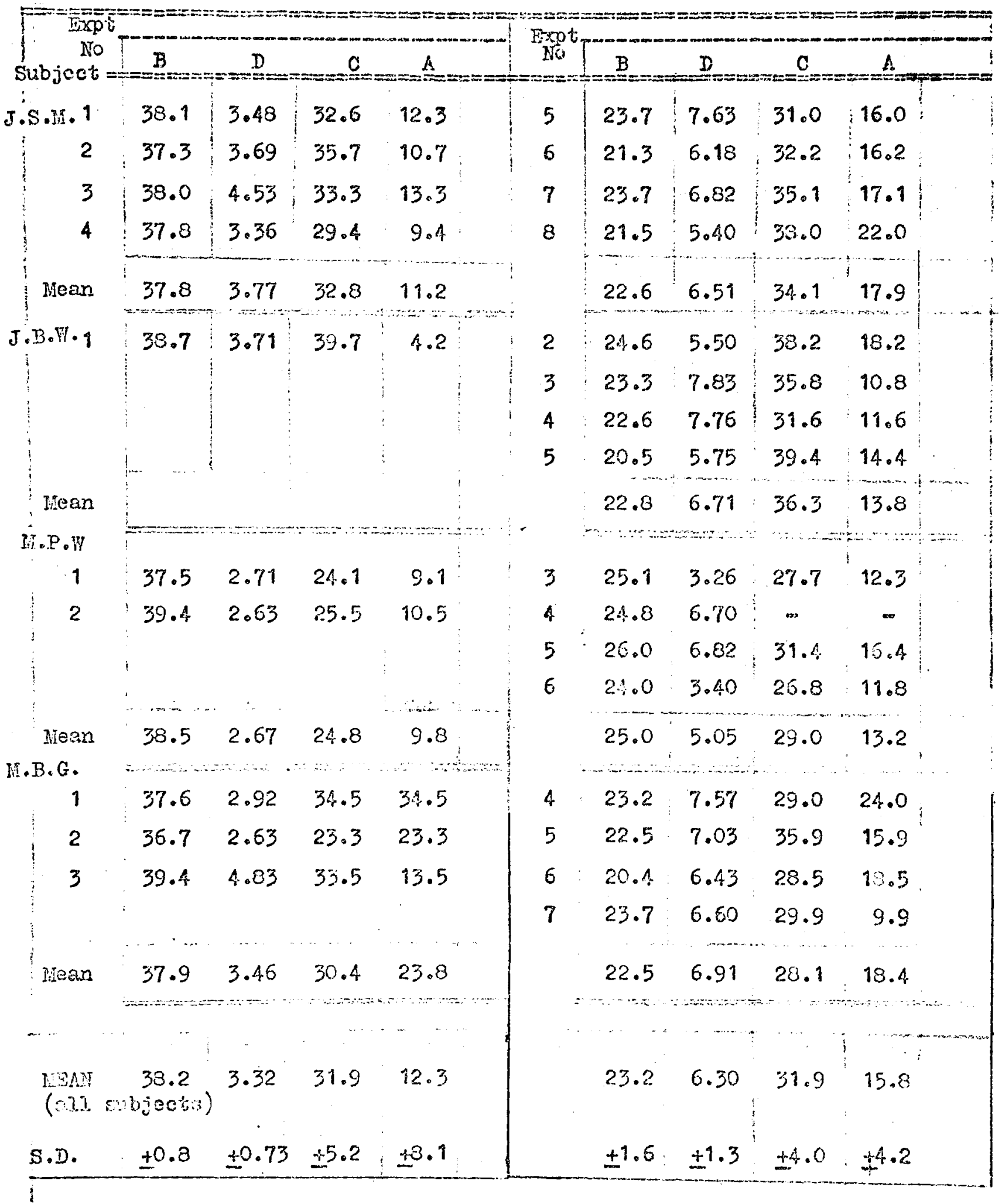




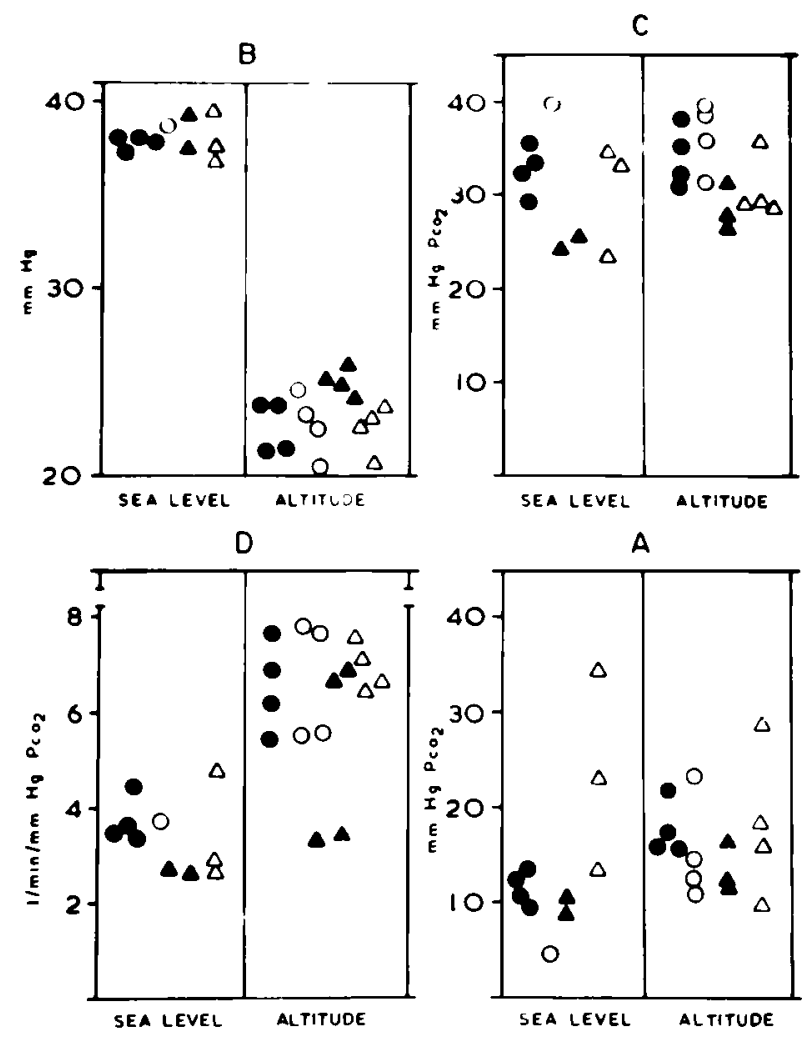

FIG. 2.5. Results of calculated respiratory paramaters on four subject: at sea level and at altitude. iach point represents one experiment. Subject JS O, JBW O, MPW MBJ $\triangle$ 
In the second expedition a further six experiments were carried out on four lowland subjects (described in full in Chapter 4). These were at slightly lower altitude, but showed the same trends. At this altitude the alveolar point on air lay within the 'fan' 1 to $2 \mathrm{~mm} \mathrm{Hg}$ above $B$, as it does at sea leve 1.

Ideally we should have liked more sea level control experiments but this was not possible. However the results we have are within the normal range as given by Cunningham, Patrick and Lloyd (1964).

$$
\begin{array}{ll}
B=37.7 \pm 2.8 \mathrm{~mm} \mathrm{Hg} & D=3.9 \pm 1.4 \mathrm{~L} / \mathrm{min} / \mathrm{mm} \mathrm{Hg} \mathrm{PcO_{2 }} \\
C=32.2 \pm 7.6 \mathrm{~mm} \mathrm{Hg} \mathrm{Po} 2 & A=16.7 \pm 11.6 \mathrm{~mm} \mathrm{Hg} \mathrm{PO} 2
\end{array}
$$

\section{DISCUSSION}

Parameter B

$A$ reduction of $B$ was expected from the $\mathrm{CO}_{2}$ response studies at altitude of Rahn, Stroud, Tenney and Mithoefer (1953), Chiodi (1957) and Kellogg, Pace, Archibald and Vaughan (1957) as well as the large number of alveolar gas measurements made on air-breathing, resting, acclimatized subjects from Fitzgerald (1913) onwards.

Gilfillan, Hansen, Kellogg, Pace and Cuthbertson (1958) have shown that the fall in alveolar $\mathrm{PCO}_{2}$ of chronically hypoxic dogs is dependent on intact chemoreceptors. They have concluded that this is direct evidence for the belief that the low alveolar $\mathrm{PcO}_{2}$ seen in acclimatized subjects even after hypoxia has been abolished is a secondary response to the hypocapnia (and consequent alkalaemia) resulting from the hyperpnoea of hypoxia. 
Cunningham, Shaw, Lahiri and Lloyd (1961), in studies on the effects of ammonium chloride acidosis on the respiratory parameters, have correlated $\mathrm{B}$ with the arterial plasma $\left[\mathrm{HCO}_{3}^{-}\right]$calculated for a $\mathrm{PcO}_{2}=\mathrm{B}$.

Unfortunately no blood gas measurements were made in conjunction with the sea level experiments reported here, and at altitude the necessary information is available only for J.S.M. and J.B.W. However, two experiments were carried out on J.S.M. two months after his return to England. Whilst these were done for a different purpose, they did involve an estimate of this subject's parameters in connection with measurements on the blood, and so provide information on the sea leve 1 $\mathrm{B} /\left[\mathrm{HCO}_{3}^{-}\right] \mathrm{B}$ relations of this subject. The averaged value from these experiments has been plotted in Fig. 2. 6 together with the determinations made on the two subjects at altitude. From the second expedition average values are also plotted for subject J.S.M. at $4,880 \mathrm{~m}$. The average slope of the $\left.\mathrm{B} / \mathrm{CCO}_{3}^{-}\right] \mathrm{B}$ relation of the acidotic subjects of Cunningham et al (1961) has been drawn through the sea level point, the extreme values being indicated by the interrupted lines. It is seen that in the acclimatized individuals the fall in $\mathrm{B}$ for a given fall in [ $\left.\mathrm{HCO}_{3}^{-}\right] \mathrm{B}$ is greater than that found by Cunningham et al. in subjects during ammonium chloride acidosis.

A difference between the acidotic and the acclimatized subject is not unexpected. Cunningham, et a1. (1961) suggested that longterm adjustments in the mechanism by which acid and $\mathrm{CO}_{2}$ affect $V$ had probably not occurred in their subjects, since the $\mathrm{B} /\left[\mathrm{HCO}_{3}^{-}\right] \mathrm{B}$ relations during the transition between normal and acid states were independent of the 


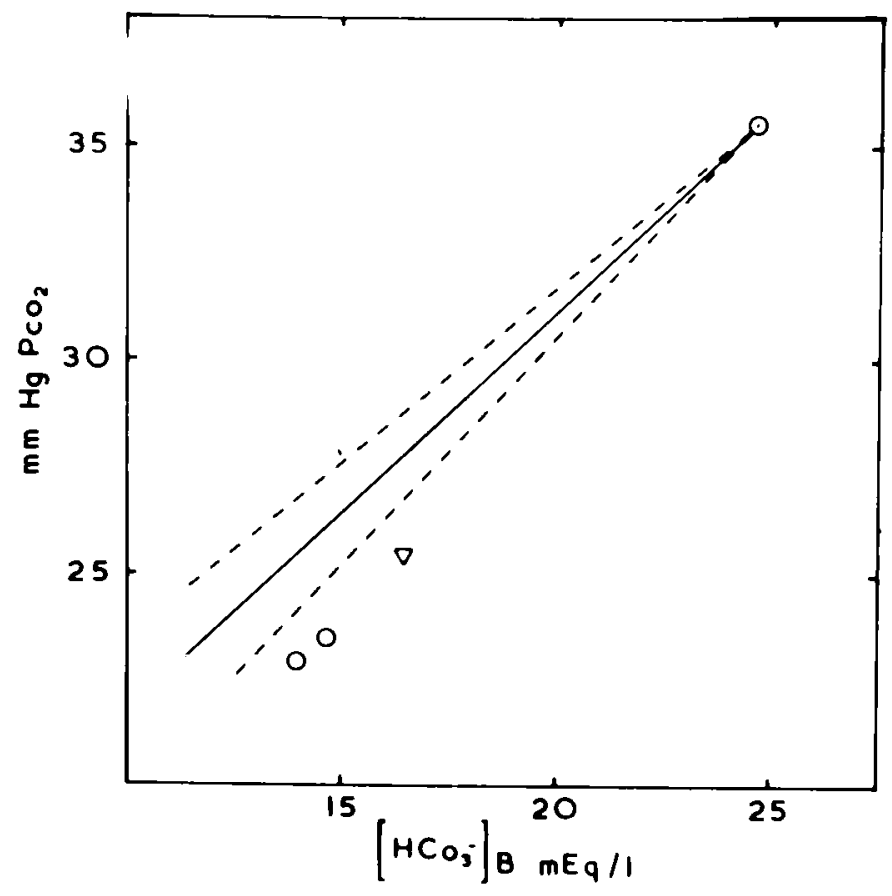

FIG. 2.6. The relation between $B$ and arterial plasma $\left(\mathrm{HCO}_{3}\right.$ at a $\mathrm{PCO}_{2}=\mathrm{B}$. The solid line ropresents the average slope obtained by Cunning am et al (1957) for this relationship in metabolic acidosis $\left(\mathrm{NH}_{4} \mathrm{Cl}\right.$ ingestion). Dashed lines show extreme values in their study. Heasurements on JSM at $5,800 \mathrm{~m} \mathrm{O,} \mathrm{JSM} \mathrm{at} 4,880 \mathrm{~m} \boldsymbol{\Delta}$, value for JSM at sea level $\odot$ (origin of line). 
direction of the change. During metabolic acid-base imbalance, modification of the CSF $\left[\mathrm{HCO}_{3}^{-}\right]$is slow (Robin, Whaley, Crump, Bickelman and Travis (1958); Bradley and Semple (1962). Such changes would appear to be of considerable importance in respiratory regulation (Leusen, $1954 a, b)$. However, these changes were presumably complete in our subjects who had been at $19,000 \mathrm{ft}$ for several months at the time measurements were made.

In studies made during the first 2 to 3 weeks of acclimatization to altitude, Kellogg (1963) has found a much greater fall in B for a given fall in $\left(\mathrm{HCO}_{3}^{-}\right) \mathrm{B}$ than was seen either in the acidotic subjects of Cunningham, et a1. (1961) or in our data.

While adjustments of CSF pH in metabolic acidosis is slow, in respiratory acidosis it has been shown to be rapid. Merwarth and Sieker (1961) in studies on hyperventilation on dogs, although they fai 1 to comment on it, show a loss of $5 \mathrm{mEq} / \mathrm{L}_{\text {of }} \mathrm{HCO}_{3}^{-}$in $\mathrm{CSF}$ after only about 40 minutes over ventilation with much smaller changes in the blood. Michel and Kao (1964) made a similar finding in dogs. Severinghaus, Mitche11, Richardson and Singer (1963) studied the change in acidbase balance in blood and CSF on going rapidly to altitude, and found that in man too the CSF rapidly lost $\mathrm{HCO}_{3}^{-}$even against a gradient of higher plasma $\left[\mathrm{HCO}_{3}^{-}\right.$] so as to maintain the $\mathrm{CSF}$ pH at near normal values, whereas the blood remained alkaline for some 5 to 8 days.

Therefore it seems possible that in Kellogg's subjects the changes accompanying acclimatization were complete (or almost complete) as far as the CSF was concerned but changes in the acid-base balance of the 
arterial blood were incomplete. By contrast, in our subjects, who had been at altitude for several months, changes in the CSF and arterial blood may both be expected to be complete. On these grounds one would predict a considerable hysteresis in the $\mathrm{B}_{\left(\mathrm{HCO}_{3}\right.}$ ] relations during the early stages of acclimatization, and the early stages of recovery (contrast with Cunningham, et a1., 1961). So far no data of this kind are available for the recovery period.

\section{Alveolar point on air}

In studies at sea level it appears that the resting alveolar $\mathrm{PCO}_{2}$ is usually $2 \mathrm{~mm}$ greater than B (Lloyd, et a1., 1958). In contrast with this, the resting alveolar $\mathrm{PcO}_{2}$ at $5,800 \mathrm{~m}$ was found to lie approximately $2 \mathrm{~mm}$ below $\mathrm{B}$ on the insensitive portion of the $\mathrm{CO}_{2}$ response curve, i.e., below the $\mathrm{CO}_{2}$ threshold of Neilsen and Smith (1951). This finding suggests that there may be a limit to the extent to which either $\mathrm{B}$ (or the arterial plasma $\left[\mathrm{HCO}_{3}^{-3}\right)$ may be lowered during acclimatization.

On the second expedition (Chapter 4) this point was found to lie as at sea level 1 to $2 \mathrm{~mm} \mathrm{Hg}$ above B. So that this limit would seem to 1 ie between $4,880 \mathrm{~m}(16,00 \mathrm{ft}$ ) (the altitude of our physiology camp) and 5,800 $\mathrm{m}(19,000 \mathrm{ft})$.

\section{Parameter D}

A rise of $\mathrm{CO}_{2}$ sensitivity in acclimatized individuals even when the hypoxia has been abolished by the inhalation of oxygen-rich gas mixtures has been observed by Neilsen (1936 a) Rahn, et a1. (1953) Chiodi (1957) and Kellogg, et al. (1957). 
It seemed possible that the reduced density of the air at altitude might lead to a reduction in the work of breathing which might account for the rise of $\mathrm{CO}_{2}$ sensitivity. Certainly if the respiratory work is greatly increased, a fall in $\mathrm{CO}_{2}$ sensitivity occurs (Cherniack and Snida1, 1956). Cotes (1954) used the equations of 0tis, Fenn and Rahn (1950) to calculate the work of breathing at maximal breathing capacity (M.B.C.) at different altitudes. His work suggested a 20 per cent reduction of respiratory work of M.B.G. at 19,000 ft. However, since the work of breathing is not a linear function of ventilation (Neilsen, $1936 \mathrm{~b})$, it does not follow that a similar reduction in respiratory work would occur at lower levels of $\dot{v}$ (i.e. 20 to $501 / \mathrm{min}$ ). No measurements of respiratory work at sea level or altitude were made in connection with the present studies. There were, however, two reasons for believing that the change of respiratory work can have no more than a very minor contribution to the observed changes in $D$.

1) Measurements were made on subjects J.B.W. and M.P.W. within a few days of the arrival at $5,800 \mathrm{~m}$. Over this period a progressive rise of $D$ was seen, although the work of breathing for a given $\dot{V}$ would have been constant.

2) A rise of $\mathrm{CO}_{2}$ sensitivity was evident in the breath-holding studies of Rahn, et a1. (1958). Work parameters were presumably not involved in the breath-holding responses. But to test this possibility we conducted the following experiment in a low pressure chamber at Royal Air Force School of Aviation Medicine, Farnborough, after return from Nepa 1. 
Pressure chamber experiments

Pressure chamber experiments were carried out on two subjects, one of which (J.S.M.) was a member of the expedition and a subject in the other experiments. A considerable amount of sea level data was available for the other subject (C.C.M.) and could be used for comparison with his responses here.

The apparatus was of a very simple form. Gas mixtures were made up in cylinders with $\mathrm{CO}_{2}$ concentrations of $3.9,5.4$ and 6.4 per cent in 40 per cent $\mathrm{O}_{2}$ for use at a barometric pressure of $760 \mathrm{~mm}$ and 7.5 , 10.2 and 13.1 per cent in 80 per cent $0_{2}$ for use at a barometric pressure of $380 \mathrm{~mm}$. There was no $\mathrm{CO}_{2}$ meter and no recorder; the expired gas was passed through a gas meter and the readings continually recorded by a clerk.

The subject inhaled each gas mixture in turn, starting with the low $\mathrm{CO}_{2}$ mixture, end-tidal samples being taken into mercury filled gas sampling tubes when ventilation became constant. In the first experiment the 'ground level' run was performed first, and followed after a $30 \mathrm{~min}$ rest by the 'altitude' run, the pressure in the chamber having been reduced to $380 \mathrm{~mm} \mathrm{Hg}$ for this. In the second experiment the order was reversed.

Fig. 2. 7 shows the results of the two experiments carried out in the pressure chamber. It will be seen that in neither case is the slope of the $\dot{V} / \mathrm{PCO}_{2}$ line increased by a fall in barometric pressure; in J.S.M. it is unchanged and in C.C.M. it is depressed. 


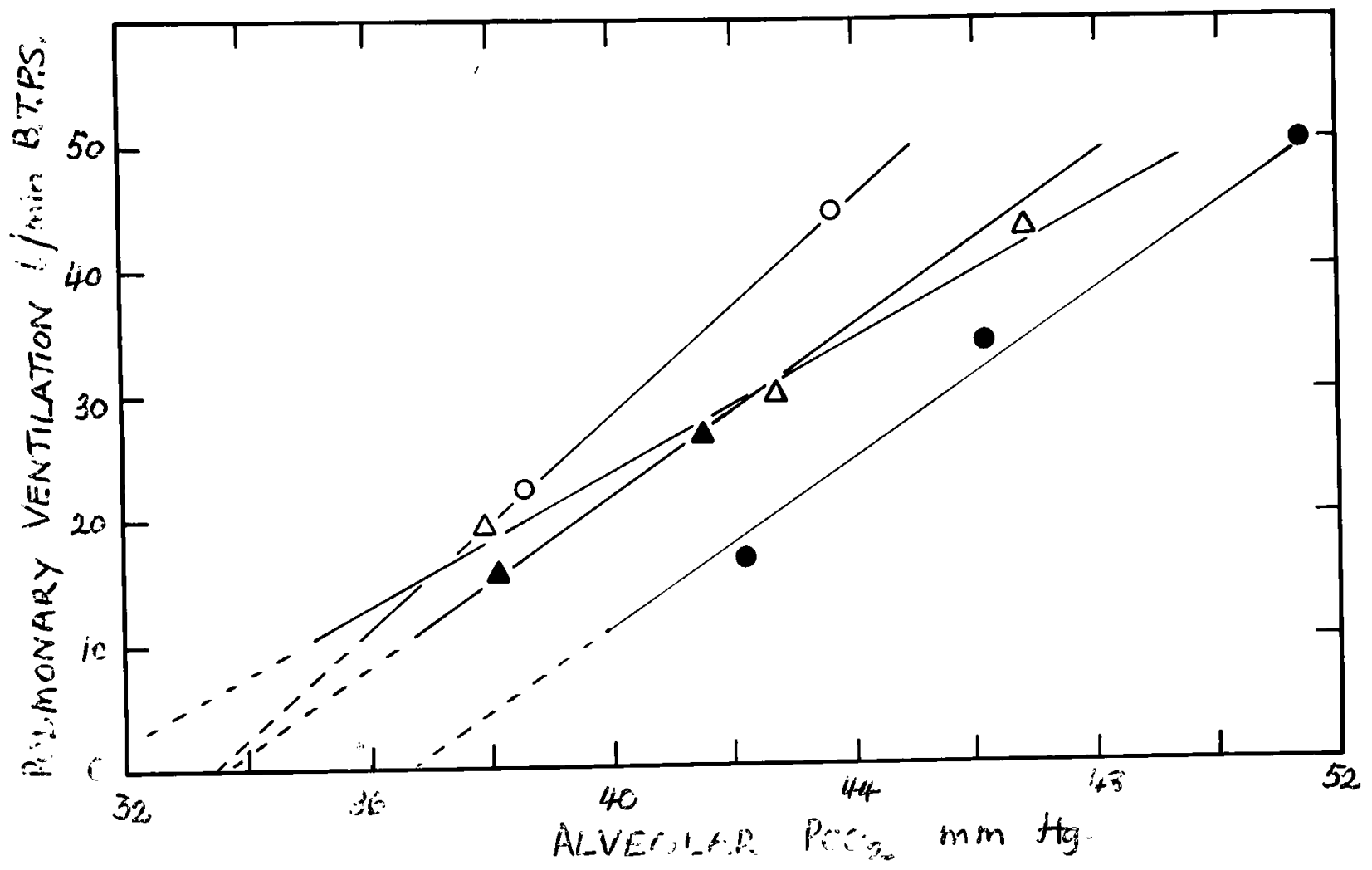

FIG. 2.7. The respiratory risponses of two subjects to inhaled $\mathrm{CO}_{2}$ at sea level and during exposure to a barometric pressure of $380 \mathrm{~mm} \mathrm{Hg}$ in a low pressure chamber, when no hypoxia was present.

o CCM at sea level;

A CCM at $380 \mathrm{~mm} \mathrm{Hg}$

- JSN at sea level;

$\Delta \quad$ JSM at $380 \mathrm{~mm} \mathrm{Hg}$ 
Although only two experiments were performed, their validity may be assessed by comparing the sea level results with other experiments on these two subjects carried out with the more sophisticated apparatus in 0xford. The sea level slopes in these experiments were 4.4 and 3.5 for C.C.M. and J.S.M. respectively. Their mean slopes for this high $\mathrm{Po}_{2}$ line in experiments at 0xford were both 3.7 .

Therefore we conclude that the effect of reduction in density and viscosity of air due to low barometric pressure produces a neglibible reduction in the work of breathing at this minute ventilation and does not account for any appreciable part of the change in $\mathrm{CO}_{2}$ response which we observed on acclimatization.

No change of $\mathrm{CO}_{2}$ sensitivity has been satisfactorily established in experimental metabolic acidosis in man. However, changes of $\mathrm{CO}_{2}$ sensitivity have been observed to accompany respiratory acidosis and alkalosis. Brown, Campbe11, Johnson, Hemmingway and Visscher (1948) observed a rise of $\mathrm{CO}_{2}$ sensitivity in norma 1 subjects overventilated in a respirator, and Schafer (1949) and Chapin, Otis and Rahn (1955) have observed a fall in $\mathrm{CO}_{2}$ sensitivity in subjects chronically exposed to atmospheres containing 4 per cent and 3 per cent $\mathrm{CO}_{2}$.

A number of workers including Winterstein (1956), Luesen (1954 a) Mitche11, Loeschcke, Severinghaus and Massion (1963) and Lambertsen, Semple, Smyth and Gelfand (1961) have suggested that the $\mathrm{CO}_{2}$ stimulus is mediated through the $\mathrm{H}^{+}$of CSF. For the CSF of our subjects to have a $\mathrm{pH}$ of 7.4 or less, the CSF $\left[\mathrm{HCO}_{3}^{-}\right]$would be considerably less than the normal sea level value (a difference of the order of 6 to $10 \mathrm{mEq} / 1$ ). The change of $\mathrm{CSF} \mathrm{pH}$ per unit change of $\mathrm{PCO}_{2}$ would now be almost double the presumed sea level value, which compares well with the observed changes of $D$. 
If, instead of plotting the results of the simple $\dot{V} / \mathrm{PCO}_{2}$ graph, Log $\mathrm{PCO}_{2}$ is used as the ordinate, then the slope of the $\mathrm{CO}_{2}$ response at high oxygen is found to be almost unchanged. We could say then that ventilatory response is directly related to $\log \mathrm{PCO}_{2}$ (Since $\mathrm{pH}$ is related to $\left.\log \mathrm{PCO}_{2}\right)$ and the increase in sensitivity at high altitude is therefore only apparent. However, if this explanation is adopted, the situation in acute metabolic acidosis, where there is no increase in sensitivity even though the $\left[\mathrm{HCO}_{3}^{-}\right]$is reduced, is difficult to explain as also is our tentative finding of a longer time course for the change in $D$ than that of $B$.

Unti 1 further light is thrown on this subject we prefer to use the simpler plot of $\dot{V} / \mathrm{PCO}_{2}$ and the parameter $\mathrm{D}$ rather than one involving a logarithm base such as suggested by Lloyd (1963).

\section{Parameters $A$ and $C$}

There has been considerable debate about the effect of acclimatization to high altitude on the ventilatory response to hypoxia (Heymans and Nei 1 1958). The parametric approach of Lloyd, et al. (1958) would appear to be particularly well suited for analysing this problem, as it clearly distinguishes between the hypoxic and hypercapnic responses. From our results it would appear that the critical alveolar $\mathrm{Po}_{2}$, at which $\mathrm{CO}_{2}$ sensitivity would become infinite (parameter $\mathrm{C}$ in the equation), is unchanged after several months at altitude. A, the parameter related to the subject's sensitivity to hypoxia, was increased in three of our subjects. As mentioned earlier, the calculation of this parameter is very susceptible to deviations in the subject's response from that 
predicted by the equation. Subject M.B.G., whose $A$ decreased at high altitude, generally gave scattered results. This was particularly true of the sea level experiments, and the sea level value of $A$ may have been overestimated in him. On the other hand, only one sea level experiment was carried out on J.B.W. in whom the largest change of A was observed.

Data from lowlanders in the second expedition is also rather inconclusive since sea level control experiments were not carried out on these subjects. One subject was common to both expeditions (J.S.M.), and his values for $A$ at altitude were again higher than his origina 1 sea level value ( 15 altitude; 11.2 sea level). The mean for all lowlanders was $15.8 \pm 4.2$ compared with a normal value of $16.7 \pm 11.6$ given by Cunningham, Patrick and Lloyd (1964). With these reservations it would appear that if any change of $A$ does occur during acclimatization, it is a small increase. There is no evidence of a decrease of oxygen sensitivity during acclimatization. This is strong evidence for the view that the hypoxic drive to breathing is maintained in the acclimatized subject (Astrand 1954 a,b; Dejours, Girard, Labrousse, Molinard and Tei 1 lac, 1957).

CONCLUSION

These experiments show that on acclimatization to high altitude, the control mechanism of lowland man becomes altered, in that the ventilatory response to $\mathrm{CO}_{2}$ appears to begin to act at a lower leve1, i.e. B is reduced (at $5,800 \mathrm{~m}$ to just over half the sea level value) 
and having begun to respond, the response is greater ( $D$ is increased) so that for a given rise of $\mathrm{PCO}_{2}$ the ventilatory response is double that at sea leve1. But the effect of hypoxia on this $\mathrm{CO}_{2}$ control system does not seem to change appreciably. If anything, its effect is slightly increased. 


\section{REFERENCES}

Chapter II

Astrand, P. 0. (1954a). A study of chemoreceptor activity in animals exposed to prolonged hypoxia. Acta. Physiol. Scand. 30, 335-342.

Astrand, P. 0. (1954b). The respiratory activity in man exposed to prolonged hypoxia. Acta Physiol. Scand. 30, 343-368.

Bradley, R. D. and S. J. G. Semple (1962). A comparison of certain acidbase characteristics of arterial blood, jugular venous blood and CSF fluid in man, and the effect on them of some acid-base disturbances. J. Physio1. 160,381-391.

Brown, E. B., G. S. Campbe 11, M. N. Johnson, A. Hemmingway and M. B. Visscher (1948). Changes in response to inhalation of $\mathrm{CO}_{2}$ before and after 24 hrs of hyperventilation in man. J. App1. Physio1. 1, 333-338.

Chapin, J. L., A. B. Otis and H. Rahn (1955). Changes in the sensitivity of the respiratory center in man after prolonged exposure to $3 \%$ $\mathrm{CO}_{2}$. W.A.D.C. Technical Report 55-357, 250-253.

Cherniac, R. M. and D. P. Snidal (1956). The effect of obstruction to breathing on the ventilatory response to $\mathrm{CO}_{2} \cdot \mathrm{J} . \mathrm{Clin}$. Invest. $35,1286-1290$.

Chiodi, H. (1957). Respiratory adaptations to chronic high altitude hypoxia. J. App1. Physio1. 10,81-87.

Cotes, J.E. (1954). Ventilatory capacity at altitude and its relation to mask design. Proc. Roy. Soc. London, Ser. B 143, 32-39.

Cunningham, D. J. C., R. S. Cormack, J. L. H. O'Riorden, M. G. M. Jukes and B. B. Lloyd (1957). An arrangement for studying the respiratory effects in man of various factors. Quart. J. Exp. Physiol. 42, 294-303.

Cunningham, D. J. C., D. G. Shaw, S. Lahiri and B. B. Lloyd (1961). The effect of maintained ammonium chloride acidosis on the relation between pulmonary ventilation and alveolar oxygen and carbon dioxide in man. Quart. J. App1. Physio1. 46, 323-334.

Cunningham, D. J. C., J. M. Patrick and B. B. Lloyd (1964). The respiratory response of man to hypoxias in Qxygen in the Animal Organism; edited by F. Dickens and E. Nie1, pp. 277-291. London: Pergamon Press. 
Dejours, P., F. Girard, Y. Labrousse, R. Molinard and A. Teillac (1957). Existence d'un stimulus oxygène de la ventilation après acclimatisation à 1 'altitude de $3,613 \mathrm{~m}$, chez 1 'Homme. C. R. Acad. Sci. (Paris) 245, 2534-2536.

Fitzgerald, M. P. (1913). The changes in the breathing and the blood at various high altitudes. Phi1. Trans. Roy. Soc. London, Ser. B $203,351-371$.

Gilfillan, R. S., J. T. Hanses, R. H. Kellog, N. Pace and E. M. Cutherbertson (1958). Physiologic study of the chemoreceptor mechanism in the dog at sea level and at altitude $(12,000 \mathrm{ft})$. Circulation 18, 724 .

Heymans, C. and E. Neil (1958). Reflexogenic Areas of the Cardiovascular System. London: Churchil1.

Kellogg, R. H., N. Pace, E. R. Archibald and B. E. Vaughan (1957). Respiratory response to inspired $\mathrm{CO}_{2}$ during acclimatization to an altitude of $12,470 \mathrm{ft}$. J. Appl. Physio1. 11, 65-71.

Kellogg, R. H. (1963). Effect of altitude on respiratory regulation. Ann. N. Y. Acad. Sci. 109, 815-828.

Lambertsen, C. J., S. J. G. Semple, M. G. Smyth and R. Glefand (1961). $\mathrm{H}^{+}$and $\mathrm{PCO}_{2}$ as chemical factors in respiratory control. J. Appl. Physio1. 16, 473-484.

Leusen, I. R. (1954a). Chemosensitivity of the respiratory center. Influence of $\mathrm{CO}_{2}$ in the cerebral ventricles on respiration. Am. J. Physiol. 176, 39-44.

Leusen, I. R. (1954b). Chemosensitivity of the respiratory center. Influence of changes in the $\mathrm{H}^{+}$and total buffer concentrations in the cerebral ventricles on respiration. Am. J. Physiol. 176, $45-51$.

Lloyd, B. B. (1958). A development of Haldane's gas analys is apparatus. J. Physiol. 143, 5-6.

Lloyd, B. B., M. G. M. Jukes and D. J. C. Cunningham (1958). The relationship between alveolar oxygen pressure and the respiratory response to carbon dioxide in man. Quart. J. Exp. Physiol. 43, 214-227.

Lloyd, B. B. (1963). The chemical stimulus to breathing. Brit. Med. Bul1. 19, 10-14.

Lloyd, B. B. and D. J. C. Cunningham (1963). A quantitative approach to the regulation of human respiration; in The Regulation of Human Respiration, edited by $D$. J. C. Cunningham and B. B. Lloyd. Oxford: Blackwe11, pp. 331-350. 
Merwarth, C. R. and H. O. Sieker (1961). Acid-base changes in blood and CSF during altered ventilation. J. Appl. Physiol. 16, 1016-1018.

Miche 1, C. C. and F. F. Kao (1964). Use of a cross circulation technique in studying respiratory response to $\mathrm{CO}_{2}$. J. Appl. Physiol. 19, 1070-1074.

Mitche11, R. A., H. H. Loeschcke, W. H. Massion and J. W. Severinghaus (1963). Respiratory responses mediated through superficial chemosensitive areas on the medulla. J. App1. Physiol. 18, 523-533.

Nielsen, M. (1936a). Untersuchungen über die atemregulation beim menchen Skand. Arch. Physio1. 74, Supp 1. 10, 83-208.

Neilsen, M. (1936b). Die respiratiomsarbeit bei körperrhue und bei muskelarbat. Skand. Arch. Physiol. 75, 299-316.

Nielsen, M. and H. Smith (1952). Studies on the regulation of respiration in acute hypoxia. Acta Physiol. Scand. 24, 293-313.

Otis, A. B., W. O. Fenn and H. Rahn (1950). Mechanics of breathing in man. J. App1. Physio1. 2, 592-607.

Rahn, H., R. C. Stroud, S. M. Tenney and J. C. Mithoefer (1953). Adaptation to high altitude: respiratory response to $\mathrm{CO}_{2}$ and $\mathrm{O}_{2}$. J. Appl. Physio1. 6, 158-162.

Robin, E. D., R. D. Whaley, C. H. Crump, A. G. Bickelman and D. M. Travis (1958). Acid-base relations between CSF and arterial blood with special reference to the control of ventilation. J. App1. Physiol. 12 , 385-392.

Schafer, J. E. (1949). Atmung und saure-basengleichgewicht bei langdauern aufenthalt in 3\% $\mathrm{CO}_{2}$. Pflug. Arch. Ges. Physiol. 251, 689-715.

Severinghaus, J. W., R. A. Mitche11, B. W. Richards on and M. M. Singer (1963). Respiratory control at high altitude suggesting active transport regulation on CSF pH. J. App1. Physio1. 18, 1155-1166.

Winterstine, H. (1956). Chemical control of pulmonary ventilation III. The "reaction theory" of respiratory control. New Engl. J. Med. 255, 331-337.

Wright, B. M. (1959). Kinetic gas analyser. J. Physio1. 149, 10. 
INTRODUCTION

Whilst experiments at rest are valuable in showing changes in the chemical control of respiration, it is on exercise that the climber is most conscious of dyspnoea. This dyspnoea is out of al1 proportion to the work he is doing, he feels, and one of the pleasant surprises on coming back to low altitude is to find that one can climb and talk again at the same time!

We studied this hyperpnoea of exercise at various work rates and at various altitudes from $4,650 \mathrm{~m}(15,300 \mathrm{ft})$ to $7,440 \mathrm{~m}(24,400$ $f t$ ) on the 1960-61 Himalayan and Scientific Mountaineering Expedition (Chapter I).

\section{METHODS and PROCEDURE}

Particulars of the subjects studied at altitude are given in Table 3.1. They were all experienced mountaineers except J.B.W. who was however accustomed to sport and had a high work capacity. 
Table 3.1. Age, height, and weight of subjects and altitude record.

\begin{tabular}{|c|c|c|c|c|}
\hline Subject & Age, yr & $\begin{array}{c}\text { Height, } \\
\mathrm{cm}\end{array}$ & $\begin{array}{c}\text { Wt., kg, } \\
\text { Before Ex- } \\
\text { pedition }\end{array}$ & $\begin{array}{c}\text { Wt., kg, } \\
\text { Circa 18/3/61 } \\
\text { at 5,800 m }\end{array}$ \\
\hline J.B.W. & 32 & 183 & 73.9 & 64.0 \\
\hline M.P.W. & 35 & 178 & 72.6 & 66.7 \\
\hline M.B.G. & 23 & 180 & 70.8 & 64.4 \\
\hline J.S.M. & 30 & 175 & 68.5 & 59.9 \\
\hline L.G.P. & 51 & 183 & 75.3 & 68.0 \\
\hline B.C.B. & 28 & 169 & 78.0 & 68.0 \\
\hline W.R. & 30 & 178 & 64.0 & 63.0 \\
\hline
\end{tabular}

\begin{tabular}{|c|c|c|c|}
\hline & & Days at Si iver \\
Subject & Date of Arrival & $\begin{array}{c}\text { Days at Mingbo, } \\
4,650 \mathrm{~m}\end{array}$ & $\begin{array}{c}5,800 \mathrm{~m} \text { to } \\
18 / 4 / 61\end{array}$ \\
\hline J.B.W. & $17 / 12 / 60$ & 41 & 82 \\
\hline M.P.W. & $17 / 12 / 60$ & 43 & 79 \\
\hline M.B.G. & $7 / 10 / 60$ & 67 & 112 \\
\hline J.S.M. & $20 / 10 / 60$ & 65 & 713 \\
\hline L.G.P. & $27 / 10 / 60$ & 80 & 70 \\
\hline
\end{tabular}

The experiments were all carried out on a portable bicycle ergometer weighing $20 \mathrm{~kg}$, built expecially for us by the workshops of the Medical Research Council, Mil1 Hi11.

The subjects pedaled at $50 \mathrm{rpm}$ in time to a metronome. Expired air was collected in light weight rubberized fabric bags 
of low $\mathrm{CO}_{2}$ permeability and passed through a dry-gas meter. At the two highest camps and in some experiments at $4,550 \mathrm{~m}(15,300 \mathrm{ft})$ gas samples were stored in $70 \mathrm{ml}$ soda-glass ampoules and analyzed in England. Otherwise all samples were drawn into Barcroft tubes over mercury and analysed in a Lloyd-Haldane analyzer (Lloyd, 1958). The reproducibility of analysis at the laboratory at $5,800 \mathrm{~m}(19,000$ $f t$ ) was comparable with results at sea leve1; $\mathrm{CO}_{2}$ values being expected to agree to within 0.03 per cent and $\mathrm{O}_{2}$ values within 0.05 per cent. Two gas meters were available, both of which were recalibrated at sea leve 1.

Al1 experiments were preceded by a $10-\mathrm{min}$ warmup at $300 \mathrm{~kg}-\mathrm{m} / \mathrm{min}$. At sea level the subjects worked for 12 mins at each of the following work rates: $300,600,900$, and $1,200 \mathrm{~kg}-\mathrm{m} / \mathrm{min}$; the work periods were taken in succession without resting. Expired gas was collected over the last minute if they could keep going longer than $2 \mathrm{~min}$.

At high altitude the same procedure was followed, the load being increased in $300 \mathrm{~kg}-\mathrm{m} / \mathrm{min}$ steps up to the highest work load. The subjects could perform for $6 \mathrm{~min}$, expired gas being collected over the last minute. In each case, a rest was allowed before the highest work load. At $5,800 \mathrm{~m}(19,000 \mathrm{ft})$ some of the subjects attempted on separate occasions to work at $1,200 \mathrm{~kg}-\mathrm{m} / \mathrm{min}$.

\section{RESULTS}

The experimental results are presented in Tables 3.2 to 3.5 and summarized in Tables 3.6 . 
TABLL 3.2 Resulls of zeork experiments at sea level

(Bar. $750 \mathrm{~mm} \mathrm{Hg}$ )

\begin{tabular}{|c|c|c|c|c|c|c|c|}
\hline Subj. & $\begin{array}{c}\text { No. } \\
\text { of } \\
\text { obs. }\end{array}$ & $\left|\begin{array}{c|c}\text { Vertilation } \\
\text { I'min } \\
\hdashline & \\
\text { STrod } & \text { RTts }\end{array}\right|$ & 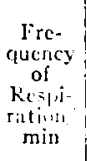 & Fren, & 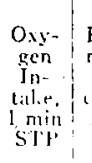 & 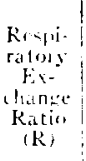 & $\begin{array}{ll}0 \\
0\end{array}$ \\
\hline & \multicolumn{7}{|c|}{ Rest } \\
\hline $\begin{array}{l}J B H \\
M P^{\prime} H^{\circ}\end{array}$ & I & $6.13>7 \cdot 5$ & 12 & 4.416 .07 & 0.31 & 0.81 & 64 \\
\hline.$M B G$ & 1 & $7 \cdot 7 \quad 9 \cdot 4$ & & $3 \cdot 33 \cdot 17 \cdot 63$ & 025 & 0.99 & $6_{\bar{j}}$ \\
\hline$J S: M$ & I & 6.0 & 9 & & & & 54 \\
\hline TON & I & $6.07 \cdot 3$ & 13 & $3.59,5.22$ & $0.3^{\circ}$ & $0.7 \mathrm{I}$ & 88 \\
\hline Mean & & 6.68 .1 & & & 0.29 & & $7^{2}$ \\
\hline \multicolumn{8}{|c|}{ Work rale, $300 \mathrm{~kg}-\mathrm{m} / \mathrm{min}$} \\
\hline MU" & $\begin{array}{l}1 \\
2\end{array}$ & $21 \cdot 326 \cdot 3$ & 25 & $4.08+6.54$ & u. $g^{4}$ & 0.90 & 95 \\
\hline$M B C$ & $\begin{array}{l}2 \\
3\end{array}$ & $\begin{array}{ll}20.7 & 25 \cdot 5 \\
10.5 & 23.7\end{array}$ & & $\begin{array}{l}4.281645 \\
4.28,1024\end{array}$ & 0.93 & $\begin{array}{l}0.93 \\
0.89\end{array}$ & $\begin{array}{l}9^{8} \\
83\end{array}$ \\
\hline$J S . M I$ & $\begin{array}{l}3 \\
2\end{array}$ & 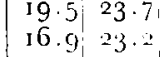 & $\begin{array}{c}20 \\
15\end{array}$ & $\begin{array}{l}4.28,10.24 \\
+613579\end{array}$ & 0.89 & 0.86 & 85 \\
\hline TON & $\mathbf{I}$ & $16.0 \quad 19.5$ & 15 & $5 \cdot 0015 \cdot 3^{6}$ & $0.9=$ & 0.87 & I 08 \\
\hline$B C B$ & 1 & 24.830 .5 & & $380,16.88$ & 102 & 0.93 & $9^{\circ}$ \\
\hline \multicolumn{8}{|c|}{ Ilush ralc, Goo ks-m/min } \\
\hline $\begin{array}{l}J B H^{\circ} \\
M P H H^{\prime}\end{array}$ & $?$ & $28 \cdot 6,3 j 3$ & 25 & $4.83: 560_{3}$ & $1 \cdot 54$ & 0.89 & 105 \\
\hline $\begin{array}{l}M P H \\
M B G\end{array}$ & I & $3^{0.6}: 37.7$ & & $4.85,15.86$ & $1 \cdot 5^{8} i$ & 0.94 & 115 \\
\hline $\begin{array}{l}M B G \\
J S W I\end{array}$ & $\mathrm{I}$ & $30 \cdot 3 \quad 37 \cdot 6$ & & $+4^{r} \cdot 6 \cdot 50^{\prime}$ & $1 \cdot 35$ & $0.9^{8}$ & 101 \\
\hline 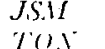 & I & $27 \cdot 2: 32 \cdot 9$ & $2 \cdot 1$ & $4.7215 \cdot 76$ & 2.14 & 0.83 & \\
\hline 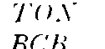 & 1 & 28.935 .1 & & 5.2715 .421 & 1.62: & 0.94 & 128 \\
\hline \multicolumn{8}{|c|}{ Hork rale, goo $\mathrm{ks-m} / \mathrm{min}$} \\
\hline$J B \|^{\circ}$ & 2 & $43 \cdot 3 \quad 53 \cdot 3$ & $2+1$ & $4 f_{1}^{\prime} f_{1} f_{1}$ & 2.08 & $0.9^{6}$ & 115 \\
\hline$M P H^{-}$ & I & $3^{8.0 .1} 53.9$ & & $5.22,5,3$ & $2 \quad 12$ & 0.93 & 133 \\
\hline.$M B G$ & 5 & $40.8,50.1$ & 26 & $4 \cdot 71 \cdot 5 \cdot 89$ & $2 . n 9$ & 0.92 & I 29 \\
\hline JSLII & I & $37 \cdot 9+9$ & 25 & $4 \cdot 8 \cdot 15 \cdot 75$ & 2.01 & 0.91 & 129 \\
\hline $70 . x$ & I & 43.953 .4 & & 4.9416 .01 & $2 \cdot i \overline{1}$ & 0.99 & 155 \\
\hline$B C B$ & 2 & $\begin{array}{r}4^{8.8}, 60.1 ! \\
\text { llork rat }\end{array}$ & \multirow{2}{*}{\multicolumn{2}{|c|}{ Whol rale, $1,200 \mathrm{~kg}-\mathrm{m} / \mathrm{min}$}} & 2.01 & $0.9^{8}$ & 110 \\
\hline$J B I^{\circ}$ & 2 & $58.3 \div 71.8$ & & 47316.16 & & $0.9^{n}$ & 139 \\
\hline MH & I & 61.475 .7 & & 4.7216 .19 & 2.93 & 0.98 & 170 \\
\hline I/ $B G$ & 5 & $\begin{array}{lll}52.2 & 63 \cdot 3 \\
\end{array}$ & 27 & $4.815 \cdot 93$ & 2.66 & 0.95 & 150 \\
\hline JS:L & I & $57 \cdot 070.3$ & & $4.70,16.10$ & $2.72\}$ & 0.99 & 154 \\
\hline TO & I & $66.5,80.8$ & & $4.33,6.63$ & 2.79 & 1.07 & 172 \\
\hline$B C B$ & 1 & 62.6776 .8 & & $4.07+6.9 f$ & $2 \cdot 4^{8}$ & 1.02 & $53^{\circ}$ \\
\hline \multicolumn{8}{|c|}{ Hork rate, $1,500 \mathrm{~g} \mathrm{~s}-\mathrm{m} / \mathrm{min}$} \\
\hline$J B H^{\circ}$ & 1 & 88.6100 .21 & 25 & $4.43^{\prime}, 16.78$ & $3.63 i$ & 1.07 & 198 \\
\hline$M I U^{\prime}$ & I & 87.8107 .9 & 34 & $4 \cdot 18: 17 \cdot 25$ & $3 \cdot 14^{\prime}$ & I. .16 & 18.4 \\
\hline WEC & 2 & 67.081 .9 & $6_{5}$ & $4.96 \div 5.13$ & $3.20 !$ & 1.03 & 176 \\
\hline JSWII & I & $\begin{array}{lll}65 \cdot 3 & 80.7\end{array}$ & & $5.021^{16}=11$ & 3.05 & 1.07 & 174 \\
\hline TON & I & $\begin{array}{llll}75 \cdot 3 & 9^{1}\end{array}$ & & $4.46,16.67$ & 3.20 & 1.05 & 193 \\
\hline$B C B$ & 1 & $\begin{array}{c}\text { I19.1 } 147.21 \\
\text { I1'ork role, }\end{array}$ & 1,800 & $\begin{array}{l}3.3318 .12 \\
.00 \mathrm{~kg}-m, \mathrm{~m}\end{array}$ & 32 & 1.22 & \\
\hline$M B G^{*}$ & I & $94 \cdot 9,115 \cdot 9$ & & $4+1017.09$ & 3.53 & 1.18 & I 80 \\
\hline$J S M \dagger$ & 1 & $121+44^{6} \cdot 5$ & $4^{6}$ & 3.66 .17 .80 & $36 j$ & $1.2 \mathrm{I}$ & 197 \\
\hline$J B W_{\ddagger} \neq$ & 2 & $125 \cdot 2,153.9$ & & 3.6017 .74 & 3.93 & 1.15 & 177 \\
\hline
\end{tabular}


TABI.E 3.3 Results of work experiments at $55,300 \mathrm{fl}(4,650 \mathrm{ml})$

(Bar. $4.0 \mathrm{~mm} \mathrm{Hg}$ )

\begin{tabular}{|c|c|c|c|c|c|c|c|c|c|c|}
\hline \multirow{2}{*}{ Date } & \multirow{2}{*}{ Sulj. } & \multicolumn{2}{|c|}{ 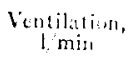 } & \multirow{2}{*}{ 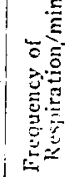 } & \multirow[b]{2}{*}{$\begin{array}{l}20 \\
\vdots \\
\vdots \\
\vdots \\
\vdots\end{array}$} & \multirow{2}{*}{$\begin{array}{r}F_{r i}:= \\
.\end{array}$} & \multirow{2}{*}{ 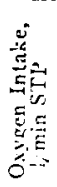 } & \multirow{2}{*}{ 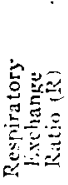 } & \multirow{2}{*}{ 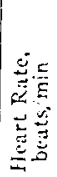 } & \multirow{2}{*}{ 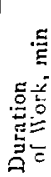 } \\
\hline & & $\stackrel{0}{0}$ & 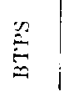 & & & & & & & \\
\hline
\end{tabular}

Itook rate, $300 \mathrm{kg-m} / \mathrm{min}$

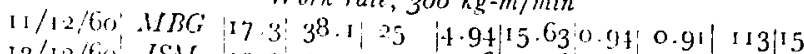

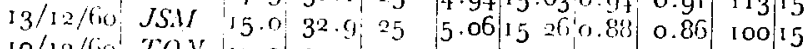

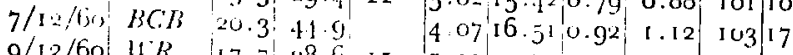

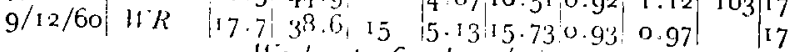

llork rale, 6oo $\mathrm{kg}-\mathrm{m} / \mathrm{min}$

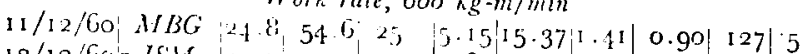

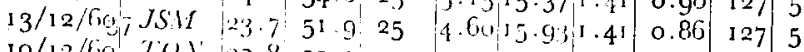

$\begin{array}{llllllllllllll}10 / 12 / 60 & T(1) & 22.8 & 50.0 & 24 & 5.31 & 5 & 22 & 1 & 33 & 0.91 & 120 & 3\end{array}$

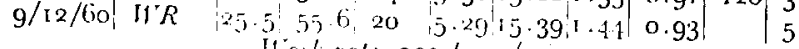

$11 / 12 / 60 \mid \mathrm{HBC}$, Itowli rale, $900 \mathrm{~kg}-\mathrm{m} / \mathrm{mm}$

\begin{tabular}{ll|l|l|l|l|l|l|l|l|l|l|}
$13 / 12 / 60$ & $J S M$ & 35.1 & 77.2 & 25 & 5.00 & 15 & 65 & 1.88 & 0.92 & 139 & 7
\end{tabular}

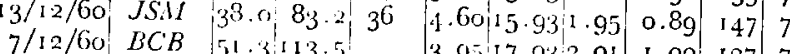

\begin{tabular}{l|l|l|l|l|l}
$9 / 12 / 60$ & 51.3153 .5 & 3.9517 .0312 .01 & I .0o & r 27 & 7
\end{tabular}

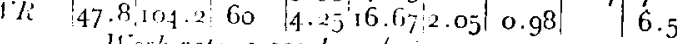
Work rate, $1,200 \mathrm{~kg}-\mathrm{m} / \mathrm{min}$

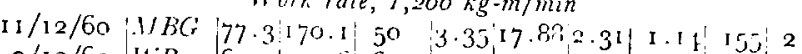

9/12/60 IIR

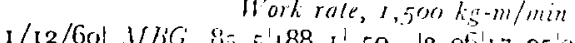

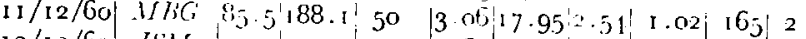

${ }_{13} / 12 / 60$ JS.1

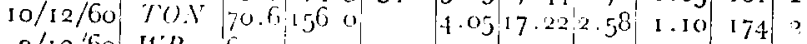

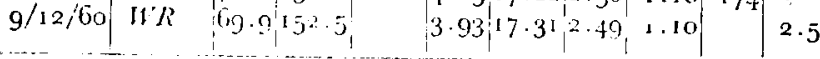

TABLE 3.4 Resulls. of wort experiments al 5,800 m (19,000 ft) (Bar. $380 \mathrm{~mm} . \mathrm{Hg}$ )

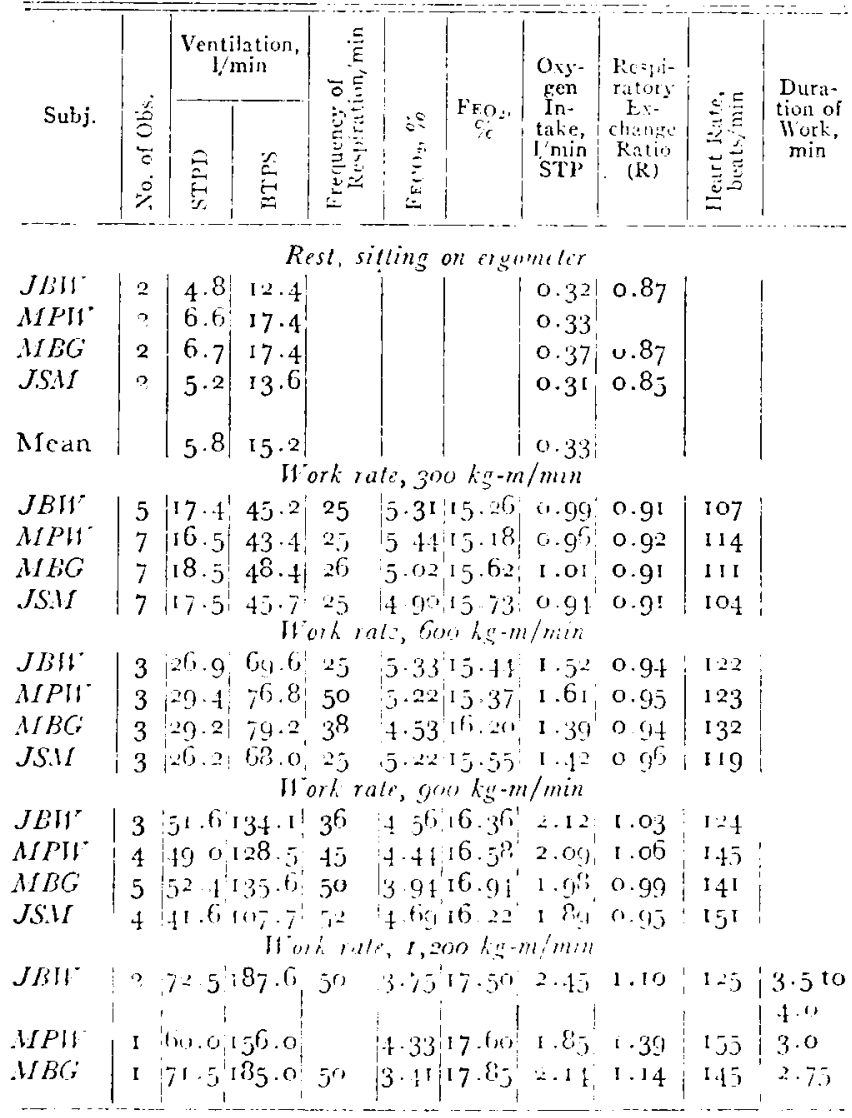


Tanis 3.5 Rrsults of work cxpriments at 6 , $400 \mathrm{~m}(21,000 \mathrm{ft})$ and $7,4.40 \mathrm{~m}(2 \mathrm{t}, 400 \mathrm{fl})$

\begin{tabular}{|c|c|c|c|c|c|c|c|c|c|c|}
\hline \multirow{2}{*}{ Date } & \multirow{2}{*}{ Subj. } & \multicolumn{2}{|c|}{ Ventilation, $l$ 'min } & \multirow{2}{*}{$\begin{array}{l}\text { Fre- } \\
\text { quency of } \\
\text { Respira- } \\
\text { tion,min }\end{array}$} & \multirow{2}{*}{ FECOOn $\because$} & \multirow{2}{*}{$\mathrm{FrO}_{2}, \%$} & \multirow{2}{*}{$\begin{array}{l}\text { Oxyoch } \\
\text { Iniate, } \\
\text { Jimin } \\
\text { STP }\end{array}$} & \multirow{2}{*}{$\begin{array}{l}\text { Reopira- } \\
\text { lory Ex- } \\
\text { change } \\
\text { Ratio (R) }\end{array}$} & \multirow{2}{*}{$\begin{array}{l}\text { Weurt } \\
\text { Ratc, } \\
\text { betats } \\
\text { min }\end{array}$} & \multirow{2}{*}{$\begin{array}{l}\text { Darstion, } \\
\min \end{array}$} \\
\hline & & $\operatorname{srp}{ }_{3 i}$ & B'A's & & & & & & & \\
\hline
\end{tabular}

Altiludc.6,700 $\mathrm{m}(2 \mathrm{~s}, 000 \mathrm{fl})($ Bor. $34.7 \mathrm{~mm} \mathrm{Hg})$

\begin{tabular}{|c|c|c|c|c|c|c|c|c|c|c|}
\hline & & & & & I'orh & tc 300 & $n / \min$ & & & \\
\hline $4 / 5 / 61$ & $J B \mathrm{I}^{\prime}$ & 16.2 & $4^{6.93}$ & 25 & & & & & 123 & 12.0 \\
\hline $5 / 5 / 6 r$ & $J B T^{\prime}$ & 17.4 & 50.9 & 25 & 4.82 & 15.80 & 0.91 & $0.9^{1}$ & 122 & 12.0 \\
\hline $2 / 5 / 6 t$ & $M P U^{r}$ & 17.1 & 50.2 & 25 . & $5 \cdot 39$ & 15.18 & 1.00 & 0.91 & 128 & 12.0 \\
\hline $5 / 5 / 61$ & WIW & 20.6 & 60.3 & 25 & 4.26 & $16.3^{0}$ & $0.9^{8}$ & 0.89 & 113 & 12.0 \\
\hline $2 / 5 / 6 I$ & $M B G$ & 18.3 & $53 \cdot 9$ & 25 & & & & & $13^{2}$ & 12.0 \\
\hline $6 / 5 / 6 I$ & $M B G$ & 17.9 & 52.1 & 25 & $4 \cdot 49$ & 16.00 & $0.9^{\mathrm{I}}$ & 0.88 & 115 & 12.0 \\
\hline $4 / 5 / 61$ & $J S . M$ & 16.2 & 47.0 & 25 & $5 \cdot 11$ & $15 \cdot 3^{2}$ & 0.93 & 0.83 & & 12.0 \\
\hline $4 / 5 / 61$ & $J S M$ & 16.6 & $4^{8 \cdot 3}$ & 25 & & & & & 118 & $7 \cdot 0$ \\
\hline $4 / 5 / 6 I$ & $J B H V$ & 23.4 & 82.6 & 25 & W or, & 16000 & $n / m e n$ & & 129 & 6.0 \\
\hline $2 / 5 / 6 \mathrm{I}$ & $M P \mathrm{IV}$ & 26.4 & 77.7 & & $4 \cdot 9^{2}$ & 15.94 & 1.33 & 0.97 & 145 & 6.0 \\
\hline $2 / 5 / 61$ & $M I E G$ & $3^{6.4}$ & 107.3 & 50 & & & & & $14^{8}$ & 6.0 \\
\hline $4 / 5 / 61$ & $J S M$ & 28.4 & 82.4 & 37 & & & & & 133 & 6.0 \\
\hline & & & & & Wor & te goo & $\mathrm{n} / \mathrm{min}$ & & & \\
\hline $4 / 5 / 6 i$ & $J B W^{\top}$ & $5^{6.0}$ & 162.6 & 50 & & & & & 142 & 5.0 \\
\hline $5 / 5 / 6$ I & $J B W$ & 57.2 & 167.4 & 50 & 3.61 & 17.53 & 1.92 & I.07 & & 5.0 \\
\hline $2 / 5 / 61$ & $M P J V$ & 50.9 & 149.8 & 50 & 3.91 & 17.16 & 1.91 & 1.04 & 161 & $5.0 ?$ \\
\hline $6 / 5 / 61$ &.$H P I V$ & $4^{6.2}$ & 135.0 & $5^{0}$ & $3 \cdot 33$ & 17.76 & 1. 45 & 1.05 & 133 & 2.75 \\
\hline $2 / 5 / 6 t$ &.$H B G$ & 60.3 & 177.5 & 50 & 3.16 & 17.8 & 1.90 & 0.99 & 144 & $4 \cdot 75$ \\
\hline $6 / 5 / 61$ & $A B G$ & $59 \cdot 3$ & 172.8 & 50 & 3.10 & 17.9 & 1.32 & 1.00 & $1: 29$ & 5.0 \\
\hline $4 / 5 / 6 !$ & J.S.II & $5^{\circ} \cdot 5$ & $1.4^{6.3}$ & 50 & & & & & 1.13 & 5.0 \\
\hline $5 / 5 / 6$ & $J S . M$ & 51.2 & 149.4 & & 3.34 & 17.2 & 1.90 & 1.03 & & $4 \cdot 5$ \\
\hline & & & & & Work & $\varepsilon 1050$ & $n / \min$ & & & \\
\hline $5 / 5 / 6 \mathrm{I}$ & $J B W$ & $6 g . \mathrm{I}$ & $202 \cdot 3$ & $5^{\circ}$ & 3.22 & 17.86 & 2.11 & 1.05 & 133 & $4 \cdot 5$ \\
\hline
\end{tabular}
Allilude $7,410 \mathrm{~m}(24,400 \mathrm{ft})\left(\right.$ Bar. $\left.300 \mathrm{mim} \mathrm{Hg}_{\mathrm{g}}\right)$

\begin{tabular}{|c|c|c|c|c|c|c|c|c|c|c|}
\hline & & \multicolumn{9}{|c|}{ 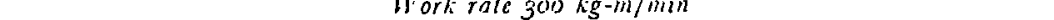 } \\
\hline $13 / 5 / 61$ & JBW & 15.2 & 5 t.8 & 25 & 5.03 & 15.25 & $0.9^{\circ}$ & 0.85 & 129 & $12.0 ?$ \\
\hline$I_{4} / 5 / 6 I$ & JWW & 16.5 & 56.0 & 25 & 5.28 & 15.18 & 0.97 & 0.89 & 131 & 12.0 \\
\hline $13 / 5 / 61$ &.$M P T w^{\prime}$ & 14.7 & jo.o & & 4.12 & 16.05 & 0.75 & 0.80 & & 12.0 \\
\hline \multicolumn{11}{|c|}{ W'ork rale bno $\mathrm{kg}_{\mathrm{g}} \mathrm{m}_{\mathrm{f}} \mathrm{min}$} \\
\hline $13 / 5 / 6 \mathrm{t}$ & $J B W$ & 37.0 & 125.7 & 50 & 3.86 & 16.97 & $1 \cdot 1^{8}$ & 0.96 & 143 & 6.0 \\
\hline $14 / 5 / 6 r$ & JBW & $3^{6.6}$ & 124.6 & 50 & $3 \cdot 9^{1}$ & 17.04 & I. +3 & 0.99 & $13^{8}$ & 6.0 \\
\hline $13 / 5 / 6 \mathrm{r}$ & $M P W^{\prime}$ & 33.6 & $11-1 \cdot 3$ & & $3.0 j$ & $17 \cdot 4^{2}$ & I. 33 & 0.83 & 129 & $5 \cdot 0$ \\
\hline
\end{tabular}


TABLE 3.6 Summary of results at sea level and at various allitudes

\begin{tabular}{|c|c|c|c|c|c|c|c|c|}
\hline \multirow[t]{2}{*}{ 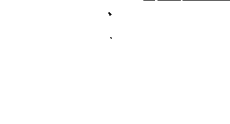 } & \multirow{2}{*}{$\begin{array}{c}\text { Rate of } \\
\text { Work, } \\
\text { kg-m } \\
\text { min }\end{array}$} & \multicolumn{2}{|c|}{ Ventilation, $1 /$ min } & \multirow{2}{*}{$\mathrm{FeCO}_{2}, c_{\mathrm{r}}$} & \multirow{2}{*}{$\mathrm{FF}_{\mathrm{O}_{2},} \%$} & \multirow{2}{*}{$\begin{array}{c}\text { Oxygen Intake, } \\
1 / \text { min STP }\end{array}$} & \multirow{2}{*}{$\begin{array}{c}\text { Respiratory } \\
\text { Exchange Ratio } \\
(\mathrm{R})\end{array}$} & \multirow{2}{*}{$\begin{array}{l}\text { Heart Rate, } \\
\text { beats/min }\end{array}$} \\
\hline & & STPD & BTPS & & & & & \\
\hline $\begin{array}{r}\text { Sea level (Bar. } \\
75^{\circ} \mathrm{mm} \mathrm{Hg} \text { ) }\end{array}$ & $\begin{array}{r}300 \\
600 \\
900 \\
1,200 \\
1,500 \\
1,800- \\
2,000\end{array}$ & $\begin{array}{l}19.6 \pm 2.8(10) \\
29.2 \pm 2 \cdot 3(8) \\
42 \cdot 3 \pm 4.0(12) \\
56.8 \pm 5 \cdot 3(11) \\
79 \cdot 7 \pm 18.5(8) \\
13.8 \pm 16.5(3)\end{array}$ & $\begin{array}{c}24.5 \pm_{3 \cdot 5(10)} \\
35.8 \pm 3.0(8) \\
52.0 \pm 4.8(12) \\
69 \cdot 4 \pm 6.7(11) \\
97.7 \pm 23 \cdot 3(8) \\
138.8 \pm 20.2(3)\end{array}$ & $\begin{array}{l}4 \cdot 3^{6} \pm 0.40(\mathrm{ro}) \\
4.64 \pm 0.40(8) \\
4.68 \pm 0.36(12) \\
4.69 \pm 0.21(\mathrm{Ir}) \\
4.54 \pm 0.59(8) \\
3.89 \pm 0.45(3)\end{array}$ & $\left\{\begin{array}{l}16.20 \pm 0.56(\mathrm{I0}) \\
16.01 \pm 0.54(8) \\
16.05 \pm 0.51(\mathrm{I2}) \\
16.19 \pm 0.43(\mathrm{II}) \\
16.67 \pm 0.73(8) \\
17.54 \pm 0.39(3)\end{array}\right.$ & $\begin{array}{l}0.94 \pm 0.05(10) \\
1.46 \pm 0.14(8) \\
2.08 \pm 0.10(\mathrm{Ir}) \\
2.72 \pm 0.14 \text { (1 } 1) \\
3.23 \pm 0.17(8) \\
3.70 \pm 0.21(3)\end{array}$ & $\begin{array}{l}0.90 \pm 0.04(10) \\
0.9^{2} \pm 0.04(8) \\
0.94 \pm 0.06(12) \\
0.9^{8} \pm 0.05(\mathrm{II}) \\
1.08 \pm 0.07(8) \\
1.18 \pm 0.03(3)\end{array}$ & $\left\{\begin{array}{l}9^{2} \pm 9(10) \\
109 \pm 10(8) \\
126 \pm 16(12 \\
151 \pm 15(11) \\
185 \pm 10(8) \\
189 \pm 10(3)\end{array}\right.$ \\
\hline $\begin{array}{l}4,65^{\circ} \mathrm{m}\left(15,3^{\circ 0}\right. \\
\text { ft) (Bar. } 44^{\circ} \\
\text { nm } \mathrm{Hg})\end{array}$ & $\begin{array}{r}300 \\
600 \\
900 \\
1,200 \\
1,500\end{array}$ & $\begin{array}{l}16.7 \pm 2.7(5) \\
24.2 \pm 1.2(4) \\
43.0 \pm 7.8(4) \\
70.9 \pm 9.0(2) \\
76.4 \pm 8.0(4)\end{array}$ & $\begin{array}{c}36.8 \pm 5.9(5) \\
53 \cdot 0 \pm 2.6(4) \\
94 \cdot 5 \pm 17.2(4) \\
155.4 \pm 20.9(2) \\
167.8 \pm 15.9(4)\end{array}$ & $\begin{array}{l}4.84 \pm 0.44(5) \\
5.25 \pm 0.09(3) \\
4.45 \pm 0.45(4) \\
3.75 \pm 0.57(2) \\
3.67 \pm 0.44(4)\end{array}$ & $\begin{array}{l}15.71 \pm 0.4^{8}(5) \\
15.33 \pm 0.09(3) \\
16.3^{2} \pm 0.64(4) \\
17.50 \pm 0.53(2) \\
17.4^{8} \pm 0.33(4)\end{array}$ & $\begin{array}{l}0.89 \pm 0.06(5) \\
1.40 \pm 0.05(4) \\
1.97 \pm 0.07(4) \\
2.3^{6 \pm 0.07(2)} \\
2.60 \pm 0.13(4)\end{array}$ & $\begin{array}{l}0.99 \pm 0.14(3) \\
0.9^{2} \pm 0.02(2) \\
0.95 \pm 0.05(4) \\
1.10 \pm 0.03(2) \\
1.06 \pm 0.04(4)\end{array}$ & $\begin{array}{l}104 \pm 6(4) \\
125 \pm 3(3) \\
139 \pm 9(4) \\
155(1) \\
167 \pm 7(3)\end{array}$ \\
\hline $\begin{array}{l}5,800 \mathrm{~m}(19,000 \\
\mathrm{ft})\left(\mathrm{Bar} .3^{80}\right. \\
\text { mm Hg) }\end{array}$ & $\begin{array}{r}300 \\
600 \\
900 \\
1,200\end{array}$ & $\left\{\begin{array}{l}17 \cdot 5 \pm 1 \cdot 5(26) \\
28.2 \pm 2.7(12) \\
46.3 \pm 13 \cdot 5(16) \\
67.0 \pm 7.4(5)\end{array}\right.$ & $\left\{\begin{array}{c}45.8 \pm 4 \cdot 1(26) \\
73.2 \pm 7 \cdot 1(12) \\
126.1 \pm 20.7(16) \\
173.7 \pm 19.0(5)\end{array}\right.$ & $\left\{\begin{array}{l}5.13 \pm 0.3 \mathrm{I}(\mathrm{i} 7) \\
5.12 \pm 0.37(\mathrm{il}) \\
4.28 \pm 0.4 \mathrm{I}(9) \\
3.8 \mathrm{I} \pm 0.4 \mathrm{I}(4)\end{array}\right.$ & $\left\{\begin{array}{l}15.49 \pm 0.4^{1}(17) \\
15.64 \pm 0.4^{2}(11) \\
16.63 \pm 0.4^{2}(9) \\
17.61 \pm 0.17(4)\end{array}\right.$ & $\left\{\begin{array}{l}0.9^{8} \pm 0.08(26) \\
1.49 \pm 0.10(11) \\
2.01 \pm 0.13(14) \\
2.25 \pm 0.27(5)\end{array}\right.$ & $\left\{\begin{array}{l}0.91 \pm 0.04(26) \\
0.95 \pm 0.02(\mathrm{rr}) \\
1.04 \pm 0.15(\mathrm{Ir}) \\
1.16 \pm 0.14(5)\end{array}\right.$ & $\left\{\begin{array}{l}\log \pm 6(14) \\
124 \pm 7(10) \\
139 \pm 11(8) \\
143 \pm 16(5)\end{array}\right.$ \\
\hline $\begin{array}{l}6,400 \mathrm{~m}(21,000 \\
\mathrm{ft})(\mathrm{Bar} .344 \\
\mathrm{mm} \mathrm{Hg})\end{array}$ & $\begin{array}{l}300 \\
600 \\
900\end{array}$ & $\begin{array}{l}17 \cdot 5 \pm 1.5(8) \\
28.7 \pm 5.6(4) \\
55.0 \pm 4.1(7)\end{array}$ & $\begin{array}{c}51.2 \pm 4 \cdot 4(8) \\
87 \cdot 5 \pm 13 \cdot 3(4) \\
160 \cdot 9 \pm 12 \cdot 4(7)\end{array}$ & $\begin{array}{l}4.81 \pm 0.45(5) \\
4 \cdot 9^{2}(\mathrm{I}) \\
3 \cdot 53 \pm 0.3^{8(5)}\end{array}$ & $\begin{array}{l}15.72 \pm 0.47(5) \\
15.94(1) \\
17.51 \pm 0.33(5)\end{array}$ & $\begin{array}{l}0.95 \pm 0.04(5) \\
\text { r } 33(1) \\
\text { r } .89 \pm 0.04(5)\end{array}$ & $\begin{array}{l}0.90 \pm 0.02(5) \\
0.97 \pm(1) \\
1.03 \pm 0.03(5)\end{array}$ & $\begin{array}{l}122 \pm 7(7) \\
139 \pm 9(4) \\
144 \pm 11(5)\end{array}$ \\
\hline $\begin{array}{l}7,440 \mathrm{~mm}(2-1,400 \\
\mathrm{ft})(\text { Bar. } 300 \\
\text { mrn } \mathrm{Hg})\end{array}$ & $\begin{array}{l}300 \\
600\end{array}$ & $\begin{array}{l}5.5 \pm 0.9(3) \\
35.8 \pm 1.8(3)\end{array}$ & $\begin{array}{r}52 \cdot 6 \pm 3 \cdot 1(3) \\
121 \cdot 5 \pm 6 \cdot 3(3)\end{array}$ & $\begin{array}{l}4.8 \mathrm{i} \pm 0.6 \mathrm{r}(3) \\
3.6 \mathrm{r} \pm 0.4^{8(3)}\end{array}$ & $\begin{array}{l}15.49 \pm 0.48(3) \\
17.14 \pm 0.24(3)\end{array}$ & $\begin{array}{l}0.87 \pm 0.11(3) \\
r .42 \pm 0.08(3)\end{array}$ & $\begin{array}{l}0.85 \pm 0.04(3) \\
0.9^{2} \pm 0.09(3)\end{array}$ & $\begin{array}{l}130(1) \\
140 \pm 3(3)\end{array}$ \\
\hline
\end{tabular}

Figures in parentheses represent number of observations. 
Oxygen intake and work rate

Fig. 3.1 shows the relation of oxygen intake to work rate at sea level and at various altitudes up to $7,440 \mathrm{~m}(24,400 \mathrm{ft})$. The relation is a straight line and independent of altitude. Data from shorter tests in which the subjects failed to keep going for 5 min are not shown, because the duration and $\mathrm{O}_{2}$ increments were highly variable; some subjects failed before their $\mathrm{O}_{2}$ intakes had reached the leve 1 attained at the preceding work rate, while others increased their oxygen intake, but never by as much as 0.5 liters/min unless they kept going for 5 min (Table 3.2). These results are of value when determining maximum $\mathrm{O}_{2}$ intake, but not when the relation between oxygen intake and work rate is under consideration.

The results obtained at Mingbo $(4,650 \mathrm{~m}, 15,300 \mathrm{ft})$ were unfortunately poorly controlled, and owing to a misunderstanding, the subjects did not exercise for the minimum period of $5 \mathrm{~min}$ at $1,200 \mathrm{~kg}-\mathrm{m} / \mathrm{min}$, although they could have done so, and the $\mathrm{O}_{2}$ intakes do not show the expected increase over the $900 \mathrm{~kg}-\mathrm{m} / \mathrm{min}$ values (Table 3.3 ). The only other aberrant value is the one on M.P.W. working at $600 \mathrm{~kg}-\mathrm{m} / \mathrm{min}$ at $6,400 \mathrm{~m}$ $(21,000 \mathrm{ft})($ Table 3.5$)$. The gas analysis is the probable source of error, since the sample was too small to be analyzed satisfactorily. Ventilation

Fig. 3.2 shows the relation of ventilation BTPS and ventilation STPD to oxygen intake, the results of al1 subjects are averaged. This relationship is often shown as a curve gradual in light exercise and steepening in heavy exercise. However, many authors including Gray, 1950; Grodins, 1950; Asmussen, Nielsen and Wieth-Pettersen, 1943 and 


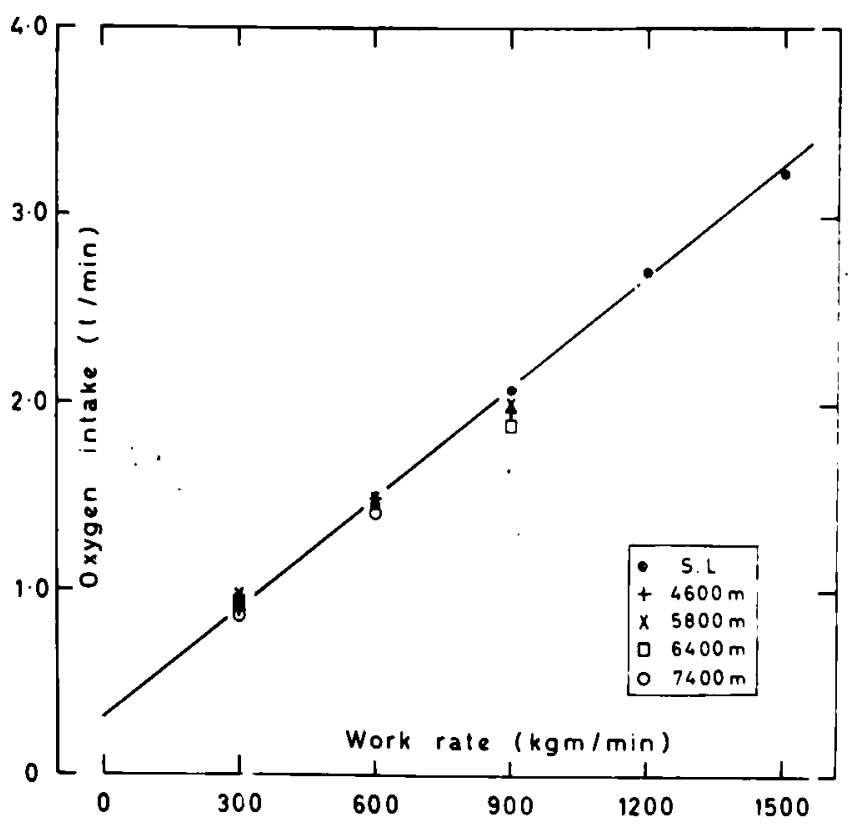

FIG. 3.1. The relation of work rate to oxygen intake at various altitudes. Each point represents the mean of all subjects studied at the given altitude. 


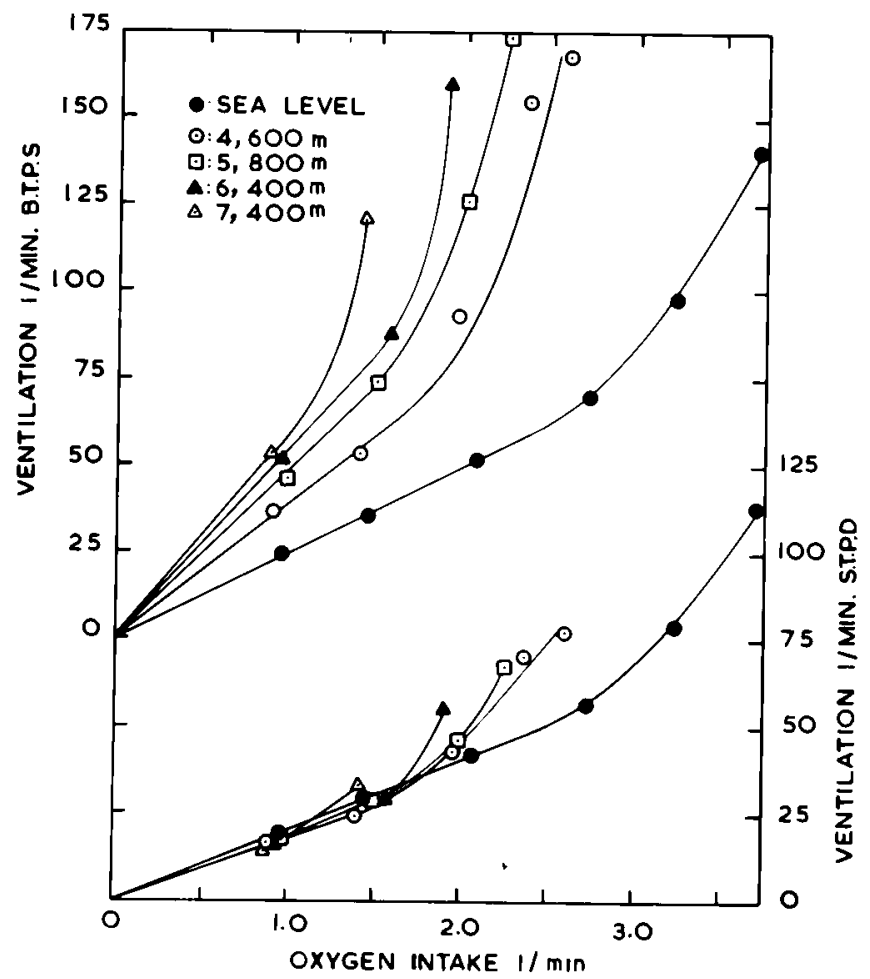

FI. 3.2. The relation of ventilation to $\mathrm{O}_{2}$ intake at various altitudes from sea level to $7,400 \mathrm{~m}(24,400 \mathrm{ft})$. Bach point represents the mean of all subjects studied at that altitude. 
Kao,(1963) have shown it to be a linear relationship unt 1 maximum work rate is approached when it breaks away and steepens. Our sea leve 1 data support this linear relationship and our altitude data are also consistent with it, with the proviso that as altitude is increased, and maximum work rate reduced, the breakaway point or region is shifted progressively to lower work rates.

It is seen that as altitude is increaseds ( $i$ ) the slope of the ventilation/oxygen intake response line steepens (at submaximum work rates), ( $i i$ ) that the breakaway region is at progressively lower $\mathrm{O}_{2}$ intakes, and ( $i$ i ) beyond the breakaway region the curve steepens faster (Fig. 3.2).

The final rapid rise in ventilation for only a small increase in work-rate exactly parallels the sensation of extreme dyspnoea of even easy climbing at extreme altitude.

This breakaway region in our subjects is:
at sea leve 1
about $2.61 / \mathrm{min} \mathrm{O}_{2}$ intake $(1,100 \mathrm{~kg}-\mathrm{m} / \mathrm{min})$
at $4,600 \mathrm{~m}$
about $1.8 \mathrm{l} / \mathrm{min} \mathrm{O}_{2}$ intake $(900 \mathrm{~kg}-\mathrm{m} / \mathrm{min})$
at $5,600 \mathrm{~m}$ and $6,400 \mathrm{~m}$
about $1.51 / \mathrm{min} \mathrm{O}_{2}$ intake $(600 \mathrm{~kg}-\mathrm{m} / \mathrm{min})$
at $7,400 \mathrm{~m}$
about $1.2 \mathrm{l} / \mathrm{min} \mathrm{O}_{2}$ intake $(300 \mathrm{~kg}-\mathrm{m} / \mathrm{min})$

Relationship between ventilation, $\mathrm{O}_{2}$ intake and altitude at submaximum work rates

We have confirmed that the ventilation expressed as liters per minute STPD is independent of altitude for work rates where the ventilation $/ \mathrm{O}_{2}$ intake response is 1 inear. This was found b' Christensen and Forbes 1937, quoted by Pugh, 1958. 
Therefore it is possible to predict what the ventilation BTPS will be for any given altitude and work rate, or more correctly, for any given barometric pressure (PB) and $\mathrm{O}_{2}$ intake.

For a given $\mathrm{PB}$ and $\mathrm{O}_{2}$ intake,

$$
\dot{v}=\dot{v}_{S T P D_{S L}} \cdot f
$$

where $\dot{V}$ is the predicted ventilation, 1/min BTPS,

$\dot{V}_{S_{T P D}}$ is the ventilation, $1 / \mathrm{min} S$ TPD for the given $O_{2}$ intake at sea leve1, and

$f$ is the conversion factor STPD to BTPS for the given $P_{B}$.

We have shown that at sea level the ventilation $/ \mathrm{O}_{2}$ intake $\left(\begin{array}{ll}0 & O_{2}\end{array}\right)$ response is linear, its slope being the ventilation equivalent (VE) Therefore

$$
\dot{\mathrm{V}}_{S T P D_{S L}}=\dot{\mathrm{VO}_{2}} \cdot \mathrm{VE}
$$

by combining the equations (1) and (2) we get:

$$
\dot{v}=\dot{V} O_{2} \cdot V E \cdot f
$$

The results of applying this equation is shown in Table 3.7 where the predicted ventilation is shown against the actual observed ventilation for the four camps where we made observations. It will be seen that with the exception of one work rate at the highest camp, all the predictions fall within one standard deviation of the observed result. In the exceptional case, the prediction is higher than the observed, possibly because the severe hypoxia was affecting the working of the respiratory muscles. Maximum ventilation at this altitude was strikingly less than at the lower camps. 
TABLE 3.7. Correlation between predicted and actual ventilation at various altitudes and various sub-maximal work rates.

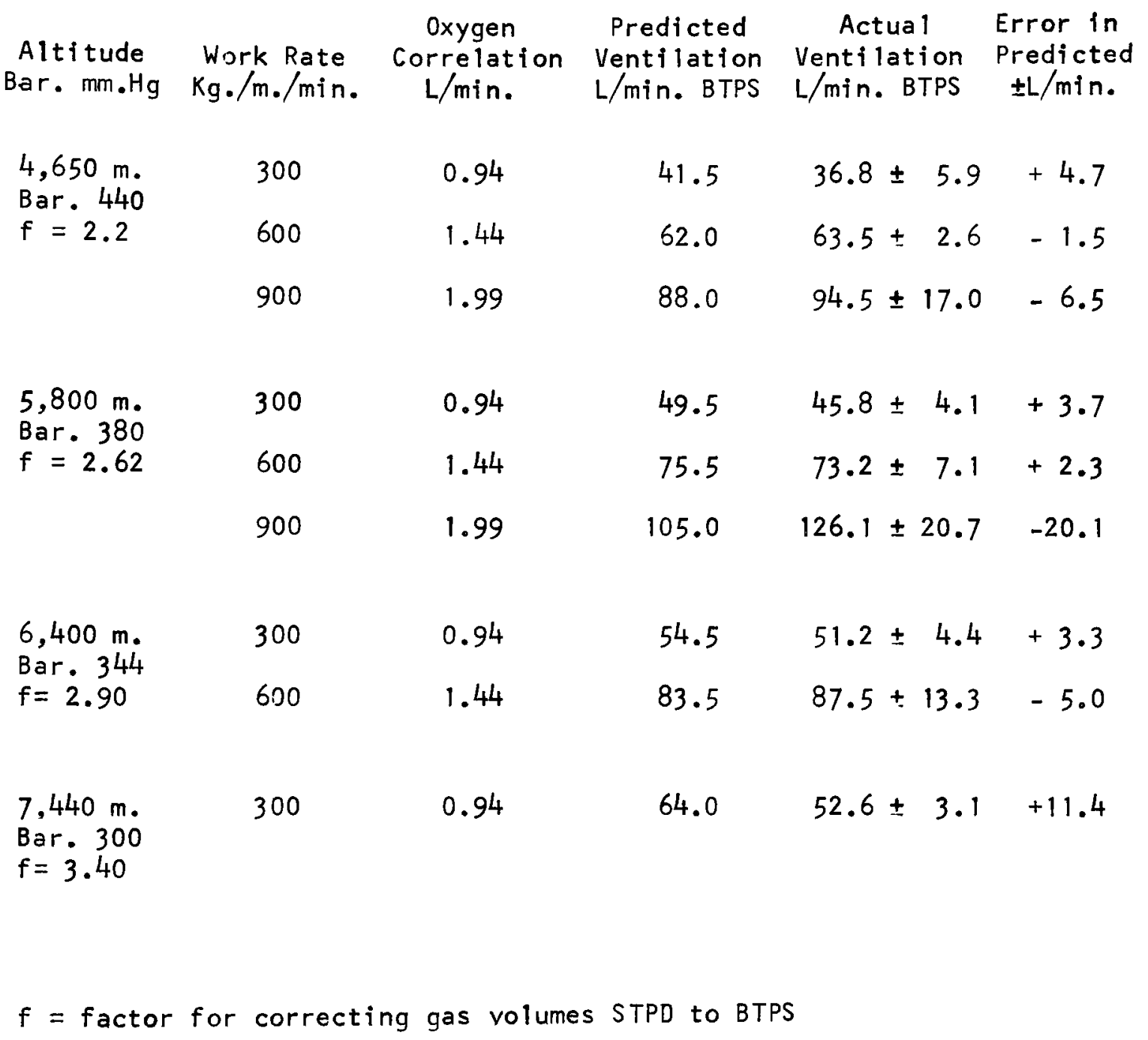




\section{Effects of added inspired oxygen}

At the end of the expedition a few experiments were conducted to observe the effect on ventilation of removing the stimulus of hypoxia by supplying an oxygen enriched gas so that the $P_{I} O_{2}$ was $150 \mathrm{~mm} \mathrm{Hg}$.

The results of three experiments, one at 4,650 $\mathrm{m}$ and two at $5,800 \mathrm{~m}$ are shown in Table 3.8 and Fig. 3.3 together with one such experiment from the second expedition (a1t $4,880 \mathrm{~m}$ ).

It is seen that the effect on breathing gas with sea leve $1 \mathrm{P}_{\mathrm{I}_{2}} \mathrm{O}_{2}$ was to reduce the ventilation considerably especially at high work rates. The maximum work rate was also increased by about $300 \mathrm{~kg}-\mathrm{m} / \mathrm{min}$, and the sensation of dyspnoea was greatly reduced. But the ventilation and maximum work rate were not restored to sea leve 1 values. This is in accord with previous workers, including Astrand (1954a and b) and Dejours, Kellogg and Pace (1963).

Exercise experiments with acute hypoxia at sea level

Experiments were carried out at CMC Vellore in November 1966 and March 1967. At first gas mixtures were made up by rebreathing air and passing it through soda $1 \mathrm{ime}$, but the sma11 quantity of $\mathrm{CO}_{2}$ remaining (0.1-0.3 per cent) was sufficient to significantly affect ventilation. These experiments were therefore rejected and in the last series gas mixtures were made up from cylinder nitrogen and air in 3001 meteorologica 1 balloons.

The subject (J.S.M.) was the same as for two of the altitude experiments on whom considerable data were already available. A standard bicycle ergometer and standard methods of gas collection were used. 
TABLE 3.8. Effect on ventilation of adding oxygen to the inspired gas - $\mathrm{PI}_{\mathrm{I}_{2}} 150$, at various a 1 titudes.

Compare with ventilation on ambient $P_{I} O_{2}$ in Tables 3.2-3.6.

\begin{tabular}{|c|c|c|c|c|}
\hline Altitude & Subject & $\begin{array}{l}\text { Work Rate } \\
\mathrm{Kg} \text {. m. min. }\end{array}$ & $\begin{array}{c}\text { Ventilation } \\
\text { BTPS }\end{array}$ & $\begin{array}{l}\text { L/min. } \\
\text { STPD }\end{array}$ \\
\hline $\begin{array}{l}4,650 \mathrm{~m} . \\
\text { Bar. } 440\end{array}$ & $\begin{array}{c}\text { J.S.M. } \\
11 \\
11 \\
11\end{array}$ & $\begin{array}{l}300 \\
600 \\
900\end{array}$ & $\begin{array}{l}34.0 \\
50.0 \\
63.0\end{array}$ & $\begin{array}{l}15.5 \\
22.8 \\
28.8\end{array}$ \\
\hline $\begin{array}{l}4,880 \mathrm{~m} . \\
\text { Bar. } 420\end{array}$ & $\begin{array}{c}\text { J.S.M. } \\
1 "\end{array}$ & $\begin{array}{r}475 \\
900 \\
1265\end{array}$ & $\begin{array}{l}35.2 \\
54.6 \\
74.5\end{array}$ & $\begin{array}{l}15.1 \\
23.6 \\
32.2\end{array}$ \\
\hline $\begin{array}{l}\text { 5,800 m. } \\
\text { Bar. } 380\end{array}$ & $\begin{array}{l}\text { M.P.W. } \\
\text { M.B.G. } \\
\text { M.P.W. } \\
\text { M.B.G. } \\
\text { M.P.W. } \\
\text { M.B.G. } \\
\text { M.B.G. } \\
\text { M.P.W. }\end{array}$ & $\begin{array}{r}300 \\
300 \\
600 \\
600 \\
900 \\
900 \\
1200 \\
1500\end{array}$ & $\begin{array}{r}34.9 \\
30.3 \\
54.0 \\
49.2 \\
85.0 \\
69.4 \\
92.2 \\
122.6\end{array}$ & $\begin{array}{l}13.4 \\
11.6 \\
20.7 \\
18.9 \\
32.5 \\
26.6 \\
35.4 \\
47.0\end{array}$ \\
\hline
\end{tabular}




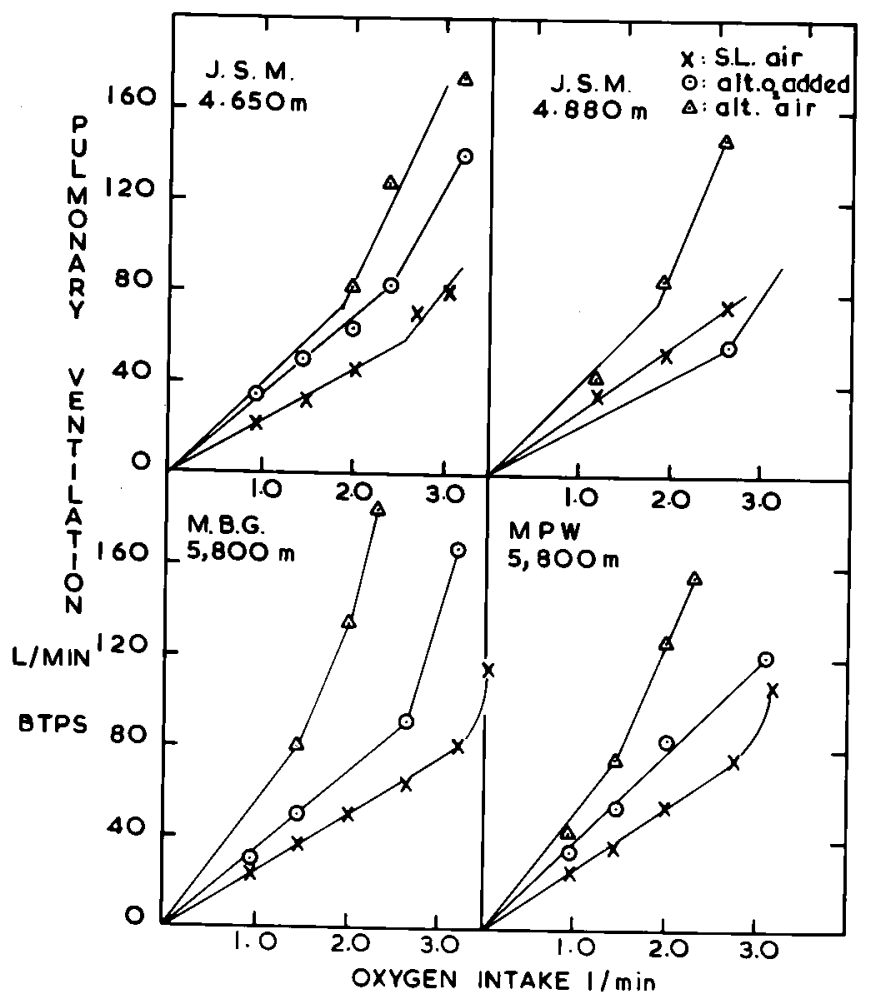

FIG. 3.3. The effect of added $\mathrm{O}_{2}$ to the inspired gas. The relation of ventilation to $\mathrm{O}_{2}$ intake at sea level $\mathrm{X}$, acclimatized breathing air $\boldsymbol{\Delta}$ and acclimatised, breating $\mathrm{O}_{2}$ enriched gas, $\mathrm{PIO}_{2} 150 \mathrm{~mm} \mathrm{Hg}, \mathrm{O}$. Each graph shows the result of one experiment at the altitude indicated 
The inspired gas mixtures were made up and found by analys is to have $\mathrm{PO}_{2}$ of: 147 (air), 105, 82, and $76.5 \mathrm{~mm} \mathrm{Hg}$. Analys is was by Lloyd-Haldane apparatus (Lloyd, 1958).

Since we had shown that at light and moderate work the $\mathrm{V} / \mathrm{O}_{2}$ intake relationship was linear, only one work rate was adopted $(300 \mathrm{~kg}-\mathrm{m} / \mathrm{min})$ which gave an oxygen intake close to $11 / \mathrm{min}$.

The results of these experiments are shown in Table 3.9, together with the calculated ventilation equivalents.

Acute and Chronic hypoxia

The effect on ventilatory control of hypoxia can be shown by plotting the ventilatory equivalent against the $\mathrm{P}_{1} \mathrm{O}_{2}$. This is done for both acute and chronic hypoxia in Fig. 3.4 together with two points from the literature.

For chronic hypoxia, pooled data of a 11 subjects, it will be seen that the points lie very close to a straight line with an origin at $100 \mathrm{~mm} \mathrm{Hg} \mathrm{P} \mathrm{I}_{2}$ and a slope of $0.71 / \mathrm{min}$ per mm Hg Po 2 decrease. For acute hypoxia, as far as the meagre data go, a very similar relationship is found. Up to $\mathrm{PIO}_{\mathrm{I}_{2}} 100 \mathrm{~mm} \mathrm{Hg}$ there is no significant increase in VE. The VE rises linearly with decreasing $\mathrm{P}_{\mathrm{I}_{2}} \mathrm{O}_{2}$, the origin being about $91 \mathrm{~mm} \mathrm{Hg}$ and the slope $1.1 \mathrm{l} / \mathrm{min}$ per $\mathrm{mm} \mathrm{Hg} \mathrm{Po} 2$.

\section{DISCUSSION}

The results of sea level experiments are closely comparable with those of other workers with respect to oxygen intake and ventilation for a given work rate on the bicycle ergometer (Fig. 3.1) (Astrand and Astrand, 1958; Astrand, Astrand, Christensen, and Hedman, 1960). 
TABLE 3.9. Results of work experiments with acute hypoxin at vellore (Bar. $746 \mathrm{~mm}$. Hg). Subject J.S.M.

\begin{tabular}{|c|c|c|c|c|c|}
\hline & Work $\mathrm{Ra}$ & & Ventilat & on $\mathrm{L} / \mathrm{min}$. & \\
\hline $\mathrm{O}_{2}$ & $\mathrm{Kg} \cdot / \mathrm{m} . / \mathrm{min}$. & L/min. & STPD & BTPS & lent \\
\hline
\end{tabular}

$\begin{array}{llllll}147 & 360 & 0.953 & 19.0 & 23.4 & 24.5 \\ 105 & 380 & 0.993 & 20.2 & 24.9 & 25.0 \\ 82 & 360 & 0.785 * & 27.7 & 34.1 & 35.0 \\ 76.5 & 360 & 1.280 * & 32.4 & 40.0 & 41.0\end{array}$

*It is probable that these values are in error. They are determined by the difference between inspired and expired $\mathrm{O}_{2} \%$ which at high ventilation is small. In calculating ventilatory equivilent $a \mathrm{~V} \mathrm{O}_{2}$ of $0.953 \mathrm{1} / \mathrm{min}$. is assumed. 
The increase in ventilation on exercise with altitude is also well known. Our subjects were able to achieve oxygen intakes comparable with those on the Mount Everest expedition (Pugh, 1958) and greater than nonmountaineers e.g. Christensen (1937) and Houston and Riley (1947).

Ventilation STPD

With changing altitude ventilation at moderate work rates was constant when reduced to STPD. Does this indicate a ventilatory control system maintaining a constant $\dot{V}_{S T P D}$ directly? I think not.

The output from the respiratory center must be related to $\dot{V}_{B T P S}$ rather than to $\dot{V}_{S T P D}$, a given neural output resulting in a given amount of respiratory work done which, if lung mechanics remain constant, and neglecting changes of viscosity and density of air, will result in a given volume of air ventilated, rather than a given mass or weight of air. That this expected result is true is born out by our low pressure chamber experiments with $\mathrm{CO}_{2}$ inhalation at Farnbrough (Chapter 2). In these experiments no acclimatization was allowed to take place between runs at sea level and simulated altitude and it was found that for the same stimulus $\left(\mathrm{P}_{A} \mathrm{CO}_{2}\right)$ the ventilation BTPS was the same (within the limits of experimental error).

The observation that $\dot{V}_{S T P D}$ is independent of altitude indicates that the respiratory control adaptations have taken place resulting in such an increase in $\dot{V}_{B T P S}$ as to supply to the lungs at altitude the same mass of air as at sea leve1.

This is then analogous to the constancy of arterial oxygen content with changing altitude brought about by the increasing haemoglobin concentration as arterial oxygen saturation decreases. 
Ventilation BTPS

The results of the present study allow us to look at the relationship of increasing ventilation BTPS with increasing altitude. If we concentrate on light and moderate work rates where the $\dot{V} / \mathrm{O}_{2}$ intake relationship is linear, we have a family of lines with increasing slope (Fig. 3.2). The slope of these lines which is the ventilation equivalent (in $1 /$ min BTPS) can be plotted against the $\mathrm{P}_{\mathrm{I}} \mathrm{O}_{2}$ for each altitude studied. This is done in Fig. 3.4. This a linear plot with an intercept at approximately $\mathrm{P}_{\mathrm{I}} \mathrm{O}_{2} 100 \mathrm{~mm} \mathrm{Hg}$ and a slope of $0.71 / \mathrm{min}$ per $\mathrm{mm} \mathrm{Hg} \mathrm{P}_{I} \mathrm{O}_{2}$ decrease. This intercept is about the same value at which an increase in ventilation is noticed at rest at sea level when the $\mathrm{O}_{2}$ per cent in the inspired gas is slowly reduced, i.e. about 13 per cent (Haldane and Priest 1y 1905).

One might have expected that the increase in slope would have been related to $\mathrm{P}_{1} \mathrm{O}_{2}$ by some exponential function but from the data we have, a linear relationship both for chronic and acute hypoxia gives the best fit.

\section{Acute hypoxia}

The effect of acute hypoxia on ventilation results in no increase in the ventilatory equivalent until a lower $\mathrm{P}_{\mathrm{I}} \mathrm{O}_{2}$ is reached than with chronic hypoxia, via about $91 \mathrm{~mm} \mathrm{Hg}$. Thereafter the effect of further reduction in hypoxia is to increase the ventilatory equivalent more rapidly than with chronic hypoxia (s lope $=1.1 \mathrm{1} / \mathrm{min}$ per $\mathrm{mm} \mathrm{Hg} \mathrm{PO_{2 }}$ decrease). If the extrapolation is justified the ventilatory equivalent (VE) for acute and chronic hypoxia would be equal at a $\mathrm{P}_{\mathrm{I}} \mathrm{O}_{2}$ of $72 \mathrm{~mm} \mathrm{Hg}$, an a 1 titude of about $5,500 \mathrm{~m}(18,000 \mathrm{ft})$. 


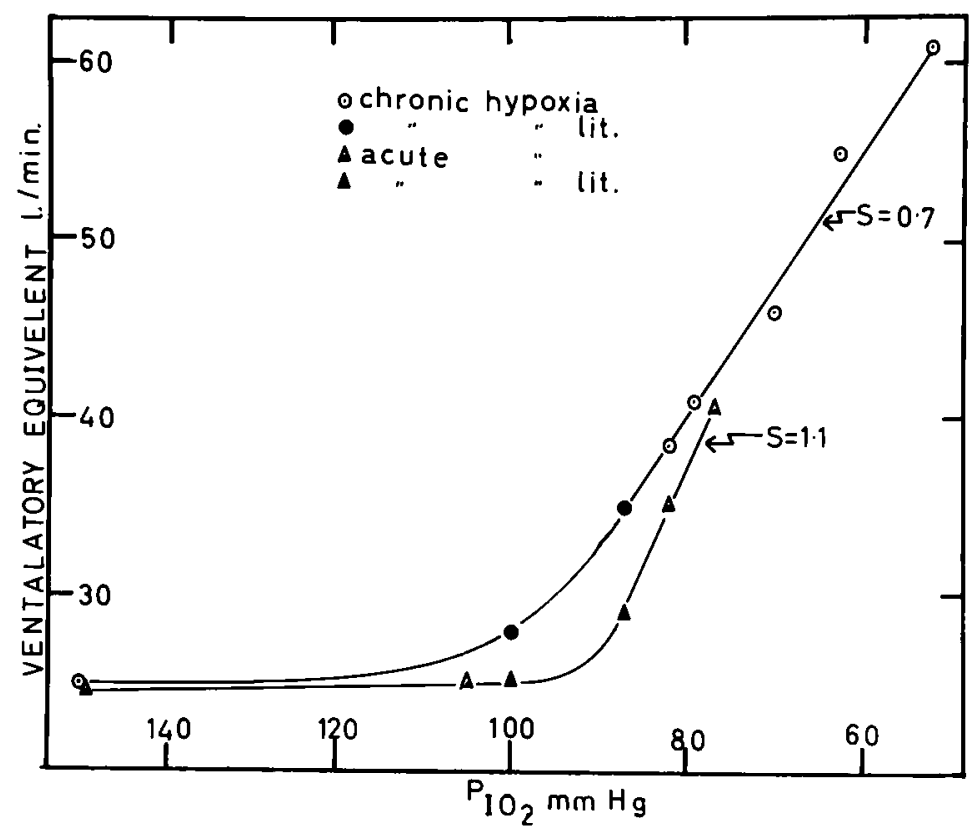

FIG. 3.4. Th relation of ventilatory equivalent to $\mathrm{PIO}_{2}$ in hypoxia; acute $\Delta$, and chronic 0 . Closed symbols from the literature, (Astrand 1954b and Dejours 1963).

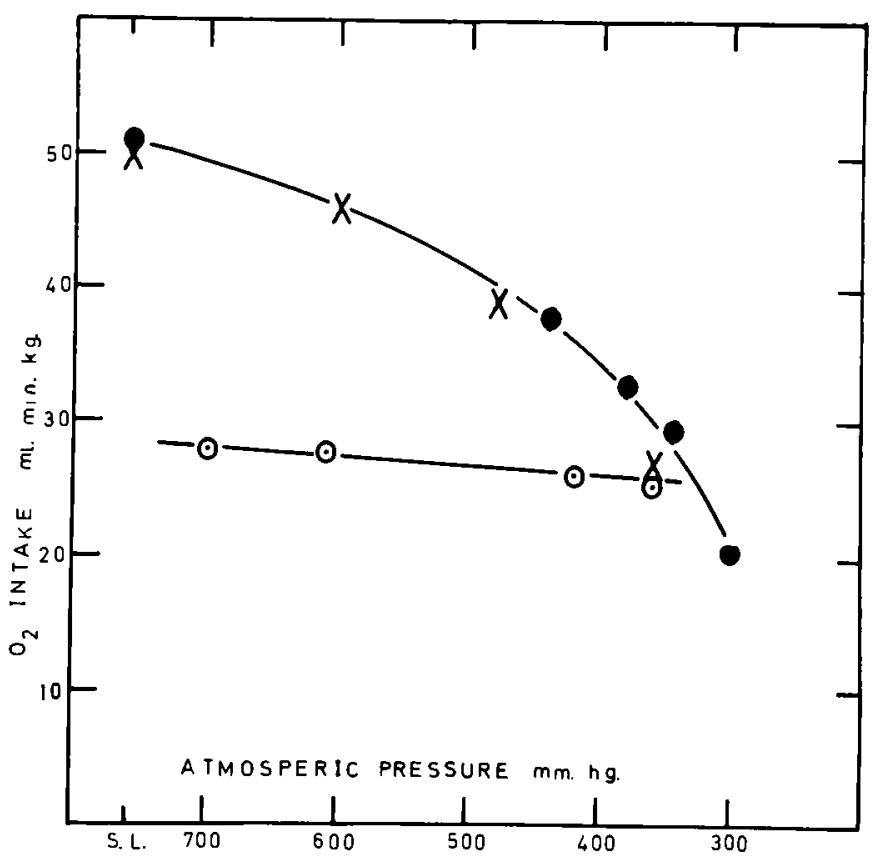

FIG. 3.5. The relation of maximum $\mathrm{O}_{2}$ intake to atmospheric pressure, present data. data of Pugh (1958), X. Lower line: average values for $\mathrm{O}_{2}$ intake of men climbing at their usual pace, 0 . 
The ventilation on moderate exercise during acute or chronic hypoxia can therefore be predicted from the following equation:

$$
\dot{V}=V o_{2} \cdot V E+s\left(x-P_{I} o_{2}\right)
$$

where $x$ is the intercept on the $V E / P_{I} O_{2}$ plot (the abcissa being VE for sea leve1)

$s$ is the slope of this line

$V E$ is the ventilation equivalent at sea leve 1 in $1 /$ min BTPS

$$
\text { For our subjects, acclimatized, } \begin{aligned}
x & =100 \mathrm{~mm} \mathrm{Hg} \quad s=0.7 \quad V E=25 \mathrm{1} / \mathrm{min} \\
\text { acute hypoxia, } x & =91 \mathrm{~mm} \mathrm{Hg} \quad s=1.1
\end{aligned}
$$

Effect of added inspired oxygen (Table 3.8 and Fig. 3.3)

The reduction in ventilation on giving sea level $\mathrm{P}_{I} \mathrm{O}_{2}$ is in agreement with previous work (Astrand, 1954b) and gives some indication of the hypoxic drive present. This was rather variable and the few results preclude any quantitation of the hypoxic drive except to note that with increasing altitude the reduction in ventilation was greater. The residual hyperventilation gives an indication of the change in $\mathrm{CO}_{2}$ sensitivity with acclimatization. This also increases with increasing altitude.

Maximum work rate (oxygen intake)

The above discussion has been limited to light and moderate work loads. At heavier work loads the relationship between ventilation and work rate or oxygen consumption departs from linear and ventilation increases very rapidly. Very high ventilations are achieved at altitude e.g. $188 \mathrm{l} / \mathrm{min}$ by M.B.G. at $4,650 \mathrm{~m}$ and $187 \mathrm{l} / \mathrm{min}$ by J.B.W. at $5,800 \mathrm{~m}$ which approaches the maximum breathing capacity. It is noteworthy that at the highest altitude, $7,440 \mathrm{~m}$, the ventilation at maximum work rate 
was only 125 and $114 \mathrm{1} / \mathrm{min}$ for the two subjects studied suggesting that possibly the respiratory muscles are limited by hypoxia.

This great increase in ventilation is presumably due to a combination of acidosis (due to anaerobic metabolism) and the effect of hypoxia itself. We showed (West, Lahiri, Gi11, Milledge, Pugh and Ward, 1962) that at high work rates the arterial oxygen saturation falls precipitously despite a rising $\mathrm{P}_{A} \mathrm{O}_{2}$ due to hyperventilation. This is because of diffusion limitations at high $\mathrm{O}_{2}$ intake.

This reduction in maximum $\mathrm{O}_{2}$ intake with altitude is shown in Fig. 3.5 which includes data from the Mount Everest Expedition (Pugh, 1958) and some values for $\mathrm{O}_{2}$ intake at comfortable climbing rates for continuous climbing. This level seems to be about $15-18 \mathrm{~m} 1 \mathrm{O}_{2} / \mathrm{kg} / \mathrm{min}$ and this is the value for maximum oxygen intake for a climber at about $6,800 \mathrm{~m}$. Since maximum $\mathrm{O}_{2}$ intake can only be maintained for a few minutes, climbers adopt an intermittent mode of climbing at altitudes well below this.

The effects of this marked hyperventilation on the acid-base balance and oxygen transport is further considered in Chapter 5.

\section{CONCLUS ION}

To meet the oxygen requirements of his exercising body lowland man at altitude has to hyperventilate very considerably. At the "silver hut" the ventilation was doubled at moderate work rates, and more than doubled at high work rates. On increasing the inspired $\mathrm{PO}_{2}$ to sea level values, the ventilation, though reduced, did not return to sea level values, indicating a change in ventilatory control with acclimatization. This change in ventilatory control presumably being a changed response to $\mathrm{CO}_{2}$ as found in the inhalation experiments (Chapter II) is a resetting of the medullary chemostat. 
REFERENCES

Chapter III

Asmussen, E., M. Nielsen and G. Wieth-Pedersen (1943). Cortical or reflex control of respiration during muscular work? Acta Physio1. Scand. $16,168-175$.

Astrand, P. 0. (1954a). A study of chemoreceptor activity in animals exposed to prolonged hypoxia. Acta Physiol. Scand. 30, 335-342.

Astrand, P. 0. (1954b). The respiratory activity in man exposed to prolonged hypoxia. Acta Physio1. Scand. 30, 343-368.

Astrand, P. 0. and I. Astrand (1958). Heart rate during muscular work in man exposed to prolonged hypoxia. J. Appl. Physio1. 13,75-80.

Astrand, P. 0., I. Astrand, E. H. Christensen and R. Hedman (1960). Circulatory and respiratory adaptation to severe muscular work. Acta. Physio1. Scand. 50, 254-258.

Christensen, E. H. and W. H. Forbes (1937). Der Kreislauf in grossen Höhen. Skand. Arch. f. Physio1. 76, 75-87.

Christensen, E. H. (1937). Sauerstoffaufrahme und respiratorische Funktionen in grossen Höhen. Skand Arch. f. Physio1. 76, 88-100.

Dejours, P., R. H. Kellogg and N. Pace (1963). Regulation of respiration and heart rate response in exercise during altitude acclimatization. J. App1. Physio1. 18, 10-18.

Gray, J. S. (1950). Pulmonary Ventilation and Its Physiological Regulation. Springfield, I11inois: Thomas, Pp. 29-46.

Grodins, F. S. (1950). An analys is of factors concerned in regulation of breathing in exercise. Physiol. Rev. 30, 220-239.

Haldane, J. S. and J. G. Priestly (1905). The regulation of lung ventilation. J. Physio1. 32, 225-266.

Houston, C. S. and R. L. Riley (1947). Respiratory and circulatory changes during acclimatization to high altitude. Am. J. Physiol. $149,565-588$.

Kao, F. (1963). An experimental study of the pathways involved in exercise hyperpnoea employing cross circulatory techniques; in The Regulation of Human Respiration, edited by D. J. C. Cunningham and B. B. Lloyd. Oxford: Blackwe11, pp. 461-503. 
Lloyd, B. B. (1958). A development of Haldane's gas analys is apparatus. J. Physio1. 143, 5-6.

Pugh, L. G. C. E. (1958). Muscular exercise on Mount Everest. J. Physiol. $141,233-261$.

West, J. B., S. Lahiri, M. B. Gi11, J. S. Milledge, L. G. C. E. Pugh and M. P. Ward (1962). Arterial oxygen saturation during exercise at high altitude. J. App1. Physio1. 17, 617-621. 


\section{H A P TER I V}

VENTILATORY RESPONSE TO $\mathrm{CO}_{2}$ AND $\mathrm{O}_{2}$ IN SHERPA HIGHLANDERS

\section{INTR ODUCTION}

Hurtado and Aste-Salazar (1948) and Chiodi (1957) found that the alveolar $\mathrm{PCO}_{2}$ in Andean high altitude residents was significantly higher than lowlanders acclimatized to a similar altitude. Also we had noted in 1960 that for a given grade of exercise in the one Sherpa in whom we measured it, the ventilation was apparently lower. This confirmed the general impression that Sherpas hyperventilate less at altitude than lowlanders, and prompted us to plan to study their respiratory response to hypoxia and $\mathrm{CO}_{2}$ in 1964 on the "Second Schoolhouse Expedition" (Chapter I).

The experiments were carried out during October and November 1964 at $4,880 \mathrm{~m}(16,000 \mathrm{ft})$, barometric pressure $420-425 \mathrm{~mm} \mathrm{Hg}$.

\section{MATERIALS}

There were three principal Sherpa subjects plus one used in the preliminary experiments only. All these men had been born and lived in a village at $4000 \mathrm{~m}$. They had a 11 been on previous mountaineering expeditions in which they had gone to heights of $6000 \mathrm{~m}$ to $7500 \mathrm{~m}$. None of them could be classed as being in the top flight of climbing Sherpas and were probably representative of the Sherpa population. The four lowland subjects were all expedition members; J.S.M. and S.L. were 
members of the physiological team and both had had previous Himalayan experience. They had spent about four to six weeks at 4,880 $\mathrm{m}$ when experiments were carried out. R.S. and J.Mc. were members of the climbing team. This was their first Himalayan expedition though they had much experience in the New Zealand Alps. They had climbed a difficult $6,400 \mathrm{~m}$ peak but had then spent two to three weeks at altitudes of $3,000 \mathrm{~m}$ $3,600 \mathrm{~m}$ and only one day at $4,880 \mathrm{~m}$ before the experiments on them were carried out. The heights, weights and ages of all subjects are shown in Table 4.1 .

Table 4.1. Physical characteristics of subjects. Where weights declined during the stay at high altitude, a mean value is taken.

\begin{tabular}{|c|c|c|c|c|c|c|c|}
\hline \multirow{2}{*}{ Subjects } & \multicolumn{3}{|c|}{ Lowlanders } & \multirow{2}{*}{ Subjects } & \multicolumn{3}{|c|}{ Sherpa } \\
\cline { 2 - 4 } & $\begin{array}{c}\text { Age } \\
(\mathrm{yr})\end{array}$ & $\begin{array}{c}\text { Height } \\
(\mathrm{cm})\end{array}$ & $\begin{array}{c}\text { Weight } \\
(\mathrm{kg})\end{array}$ & & $\begin{array}{c}\text { Age } \\
(\mathrm{yr})\end{array}$ & $\begin{array}{c}\text { Height } \\
(\mathrm{cm})\end{array}$ & $\begin{array}{c}\text { Weight } \\
(\mathrm{kg})\end{array}$ \\
\hline \hline S.L. & 32 & 158 & 56 & P. & 26 & 155 & 52 \\
\hline J.S.M. & 34 & 175 & 69 & H.N. & 35 & 165 & 65 \\
\hline R.S. & 23 & 172 & 65 & P.N. & 42 & 167 & 60 \\
\hline J.Mc & 28 & 180 & 81 & H.T. & 22 & 164 & 59 \\
\hline Mean & 29.3 & 171 & 67.8 & Mean & 31.3 & 163 & 59.0 \\
\hline
\end{tabular}

\section{METHODS}

The apparatus was the same as that used on the previous expedition (Chapter II) with the following modifications: 
1) For measuring ventilation, a Wright "respirometer" (British Oxygen Co. Ltd.) was used in place of the dry gas meter. It gave a signal for every 1 liter expired which was recorded on a clockwork pen recorder. 2) Suction for drawing end-tidal gas through the sampler was by water displacement 3) There was no $\mathrm{CO}_{2}$ meter; a steady ventilation seen on the recorder was taken to indicate a steady state, at which time a sample of end-tidal gas was drawn into a Barcroft tube.

\section{GAS MIXTURES}

Four gas mixtures were made up from air and cylinder $\mathrm{O}_{2}, \mathrm{~N}_{2}$ and $\mathrm{CO}_{2}$ so as to give a $\mathrm{P}_{\mathrm{I}} \mathrm{CO}_{2}$ of $15-20 \mathrm{~mm} \mathrm{Hg}$ and $\mathrm{P}_{\mathrm{I}} \mathrm{O}_{2}$ of approximately 54, 76, 90 and $225 \mathrm{~mm} \mathrm{Hg}$ respectively.

\section{PROCEDURE}

The procedure for the experiments was similar to the previous series. In the first group of experiments the order of bag mixtures was from low to high $\mathrm{O}_{2}$ and the latter from high to low $\mathrm{O}_{2}$. There was no apparent difference in results between these two procedures.

\section{RESULTS}

We carried out 14 full experiments measuring $\mathrm{CO}_{2}$ response at 3 or 4 different $\mathrm{O}_{2}$ levels which were technically satisfactory; 8 were on 3 Sherpa subjects and 6 were on 4 lowlanders. The results of these experiments are given in Tables $4.2 a$ and $b$, and are shown graphically in Fig. 4.1. Fig. 4.2 shows two experiments in greater detai1, one on a Sherpa and one on a lowlander.

It will be seen from Fig. 4.1 and 4.2 that in general:

1. Th? origin of the fan of isoxic lines (B) is similar in Sherpas and lowlanders. 
Table $4_{0} 2$ a. Results of experinents on Lowlanders at, altitude of $4,880 \mathrm{~m}$. Ventilation litres per min BTPS, $\mathrm{P}_{\mathrm{A}_{\mathrm{A}}} \mathrm{CO}_{2}$ ard $\mathrm{P}_{\mathrm{A}} \mathrm{O}_{2} \mathrm{~mm}$. $\mathrm{Hg}$.

Subject: So

Szbjest: I Mic.

\begin{tabular}{|c|c|c|c|c|c|c|c|c|}
\hline $\begin{array}{l}\text { Expt } \\
\text { Vento }\end{array}$ & $\sum_{\mathrm{C}_{2}}^{1}$ & $\mathrm{E}_{\mathrm{A}} \mathrm{O}_{2}$ & $\begin{array}{l}\text { Expt } \\
\text { Vent. }\end{array}$ & $\begin{array}{c}4 \\
E_{4} \mathrm{CO}_{2}\end{array}$ & $\mathrm{~F}_{\mathrm{B}} \mathrm{O}_{2}$ & $\begin{array}{l}\text { Expt. } \\
\text { Vent. }\end{array}$ & $\begin{array}{r}1 \\
\mathrm{P}_{\mathrm{A}} \mathrm{CO}_{2}\end{array}$ & $P_{A} O_{2}$ \\
\hline 8.4 & $29 \mathrm{CL}$ & 51,45 & 19.8 & 25.02 & 41.89 & 30.0 & 25.73 & 36.72 \\
\hline 6.4 & $2 \% 78$ & $200+$ & 45.2 & 26,03 & 39.83 & 42 & 28.88 & 38,64 \\
\hline 20.6 & 31.29 & $200+$ & 20.7 & 29,84 & 59.99 & 83 & 31.06 & 35.72 \\
\hline $38_{0} 5$ & 3428 & $200+$ & 47.3 & 33.50 & 56.14 & 17 & 28.53 & $\Delta G_{0} .3$ \\
\hline 45.6 & 36.69 & $200+$ & $12_{0} 6$ & 26,93 & 6624 & 83 & 32.04 & 42.48 \\
\hline 12.01 & 26.27 & $4: 1.008$ & $45_{0} 2$ & 31.53 & 62.50 & 26.5 & 30.08 & 7485 \\
\hline 25.5 & 30.50 & $\Delta C_{0} \in Z$ & 9.8 & 28.76 & $200+$ & 80 & 3509 & $68-08$ \\
\hline$\Delta 7.0$ & 32.80 & 43.71 & 32.0 & $3 \Omega_{80} 67$ & $200 *$ & 27.5 & 33.41 & $200+$ \\
\hline 17.0 & 22.71 & 33.23 & 36.6 & 35.46 & $200+$ & 75 & 36.66 & $200+$ \\
\hline 43.5 & 25.29 & 31.07 & 45.7 & 36.65 & 2004 & 83 & 43.75 & $200+$ \\
\hline \multicolumn{6}{|c|}{ Subjent Ioson } & \multicolumn{3}{|c|}{ Subjopt: ${ }^{2} S_{0}$} \\
\hline Iixpos & 3 & & Expt & 4 & & Esxpt & & \\
\hline 28.1 & 25.14 & 38.72 & 21.3 & 26,17 & $42_{3} 37$ & 49 & 31.8 .8 & 38.34 \\
\hline 62.5 & 26.86 & 38.79 & 63.4 & 28.76 & 39.74 & 70 & 31.87 & 35.04 \\
\hline 13.6 & 26.97 & 13.71 & 18.5 & $2 E_{0} 70$ & $5 \hat{s}_{0} 80$ & 23 & 29.05 & $\stackrel{51.11}{=}$ \\
\hline $2 \pi 00$ & 27.60 & $48_{0} \mathrm{O}^{\circ}$ & $71_{0} 0$ & 33045 & $51 . \mathrm{O}^{\mathrm{n}}$ & 68 & $3 \cong .59$ & 4679 \\
\hline 84.3 & 31,67 & 45.65 & 18.5 & 28,25 & $5 \%, 6$ & 1.8 & 29.15 & 02,85 \\
\hline 13.9 & 26.15 & $72.7 \%$ & 6.0 & 32.66 & 54.85 & 53 & 33.00 & 0.53 \\
\hline 55.8 & $32.86 \%$ & 65.64 & 17.3 & 28.80 & $200 \%$ & 70 & 33.89 & 56086 \\
\hline 12.2 & 27.90 & $200+$ & 53.0 & 24.55 & $200+$ & 18 & 30,37 & 200 \\
\hline 52.0 & 31.048 & $200+$ & & & & 73 & 40.59 & 200 \\
\hline
\end{tabular}


Table 4o2 b: Results of experinents on Sherpas at altitude of $4,880 \mathrm{~m}$. Ventilation litres per min BTES, $\mathrm{P}_{\mathrm{it}} \mathrm{CO}_{2}$. and $\mathrm{P}_{\mathrm{h}_{2}} \mathrm{O}_{2} \mathrm{~mm} \mathrm{hig}$.

Subjeg: Fis

Subiact: H-N

\begin{tabular}{|c|c|c|c|c|c|c|c|c|}
\hline $\begin{array}{l}\text { Expt } \\
\text { V } \\
\text { Vent. }\end{array}$ & $\begin{array}{c}3 \\
\mathrm{P}_{\mathrm{S}} \mathrm{CO}_{2} \\
\end{array}$ & $\mathrm{P}_{1} \mathrm{O}_{2}$ & $\begin{array}{l}\text { Expt } \\
\text { Tent. }\end{array}$ & $\begin{array}{c}4 \\
P_{2} \mathrm{CO}_{2}\end{array}$ & ${ }_{2} \mathrm{P}_{2}$ & Expt & $\begin{array}{c}3 \\
\mathrm{P}_{\mathrm{A}} \mathrm{CO}_{2}\end{array}$ & $\mathrm{P}_{\mathrm{A}} \mathrm{O}_{2}$ \\
\hline 12.2 & 28.99 & 47,46 & $8.0^{\circ}$ & 28,72 & 45,35 & 18.8 & 28.35 & $200+$ \\
\hline 23.5 & $32 . \mathrm{ES}$ & $200+$ & 20.7 & 26,66 & 34.73 & 54.5 & 36,6 & $200 \mathrm{t}$ \\
\hline 30.6 & $32, \Delta 5$ & $200+$ & 41.3 & 32.06 & 32.40 & 21.3 & 29.60 & 63.86 \\
\hline 50.6 & 36.01 & $200+$ & 68.8 & 35.36 & 33.18 & 68.5 & 39.55 & 62.25 \\
\hline 50.6 & 35.59 & $200+$ & 25.2 & 30.71 & 35.70 & 24.0 & $2,9.81$ & 46,35 \\
\hline 16.5 & 29.59 & 65.6 & 61.9 & 31.38 & 33.64 & 63.2 & 37.53 & 4.1 .95 \\
\hline 50.5 & 37.92 & 67.43 & 49.8 & 36.19 & 58,20 & 22.8 & 27.00 & 37.84 \\
\hline 13.7 & 30,54 & $43 . \Delta 7$ & 16.6 & 30.11 & $200^{\circ}$ & $450 \%$ & 31.28 & 33.53 \\
\hline 48.5 & 36,3 & $4 A_{0} 45$ & 35.8 & $34: 05$ & $200+$ & 73.28 & 39.35 & 30.30 \\
\hline $1 \varepsilon_{0} 0$ & 29.50 & 33.97 & 47.0 & & 200 & & & \\
\hline 30.6 & 34.04 & 32.35 & & & & & & \\
\hline 60.8 & $35.0 ?$ & 20.73 & & & & & & \\
\hline
\end{tabular}




\section{Subjest: H-N}

\begin{tabular}{|c|c|c|c|c|c|}
\hline $\begin{array}{l}\text { Expt } \\
\text { Vent. }\end{array}$ & $P_{\mathrm{A}} \mathrm{CO}_{2}^{4}$ & $\mathrm{P}_{\mathrm{A}} \mathrm{O}_{2}$ & $\begin{array}{l}\text { Expt } \\
\text { Vent. }\end{array}$ & $\begin{array}{r}5 \\
\mathrm{P}_{\mathrm{h}^{\mathrm{n}}} \mathrm{CO}\end{array}$ & $\mathrm{P}_{\mathrm{A}} \mathrm{O}_{2}$ \\
\hline 13.0 & $29_{0} A$ & $5 \hat{1}_{8} 94$ & 17.9 & 29.36 & 37.80 \\
\hline 35.0 & 29.21 & 43.24 & 53.8 & 32.66 & $3 t_{8} 31$ \\
\hline 62.9 & 33.60 & 39.30 & 17.7 & 30.04 & 48.60 \\
\hline 20.3 & 28.91 & 49.76 & 60.84 & 35.83 & 45,11 \\
\hline 71.7 & 36.04 & 46.39 & $18_{8} 3$ & 28.76 & 70.85 \\
\hline 19.0 & 28,00 & 88.05 & $54_{\mathrm{o}} 3$ & 35.25 & 65.02 \\
\hline 48.0 & 35.70 & 80.85 & 13.7 & 30.64 & $200+$ \\
\hline 21021 & 29.69 & $200 *$ & 53.5 & 37.01 & 200 \\
\hline 48.60 & 32.89 & $200+$ & & & \\
\hline
\end{tabular}

\section{Subiset: PaN}

\begin{tabular}{|c|c|c|c|c|c|c|c|c|}
\hline Expt & 2 & & Expt & 3 & & Expt & 4 & \\
\hline Vent & $\mathrm{P}_{\mathrm{A}} \mathrm{CO}_{2}$ & $\mathrm{P}_{\mathrm{H}} \mathrm{O}_{\mathrm{Z}}$ & Vent & $\mathrm{P}_{\mathrm{H}} \mathrm{CO}_{2}$ & ${ }^{P_{A}} O_{2}$ & Verts & $\mathrm{P}_{\mathrm{A}} \mathrm{CO}_{2}$ & $\mathrm{P}_{\mathrm{A}_{2}} \mathrm{O}_{2}$ \\
\hline 21.4 & 27.56 & $200+$ & $13 \neq 0$ & 27.52 & 49.20 & 16.6 & 31.64 & 35.85 \\
\hline 17.8 & 30.64 & $200+$ & 22.4 & 26.93 & $200: 3$ & 40.7 & 35.51 & 32.36 \\
\hline 32.6 & 32.07 & $200 \%$ & 15.14 & 29.29 & 68.63 & 67.0 & 37.31 & 30.19 \\
\hline $4 A_{0} 6$ & 35.31 & $200+$ & 50.0 & 37.20 & 65.36 & $1 \varepsilon_{0} 4$ & 29.65 & 49.16 \\
\hline 12.6 & 29.93. & 68.32 & 13.8 & 31.13 & $43.6:$ & 45.1 & 35.2 .5 & 47.41 \\
\hline$\Delta 1.0$ & 37.75 & 86.55 & $A .5 .9$ & 37.20 & 49.35 & 15.7 & 27.01 & 90.30 \\
\hline 14.9 & 27.11 & $4 S_{c} 25$ & 30.5 & 31.65 & 41.18 & 48.0 & 35.71 & 81,20 \\
\hline 45.9 & 35.95 & 30,80 & 50.8 & 36,65 & 37.2 & 10.0 & 28,50 & $200+$ \\
\hline 13.6 & 27.00 & 38.88 & 37.6 & 32.66 & 32.80 & 55,2 & 35.94 & $200 \%$ \\
\hline $\begin{array}{l}40.4 \\
46.4\end{array}$ & $\begin{array}{l}33.65 \\
31.33\end{array}$ & $\begin{array}{l}3.43 \\
35.72\end{array}$ & 55.5 & 35.93 & 30.75 & & & \\
\hline
\end{tabular}




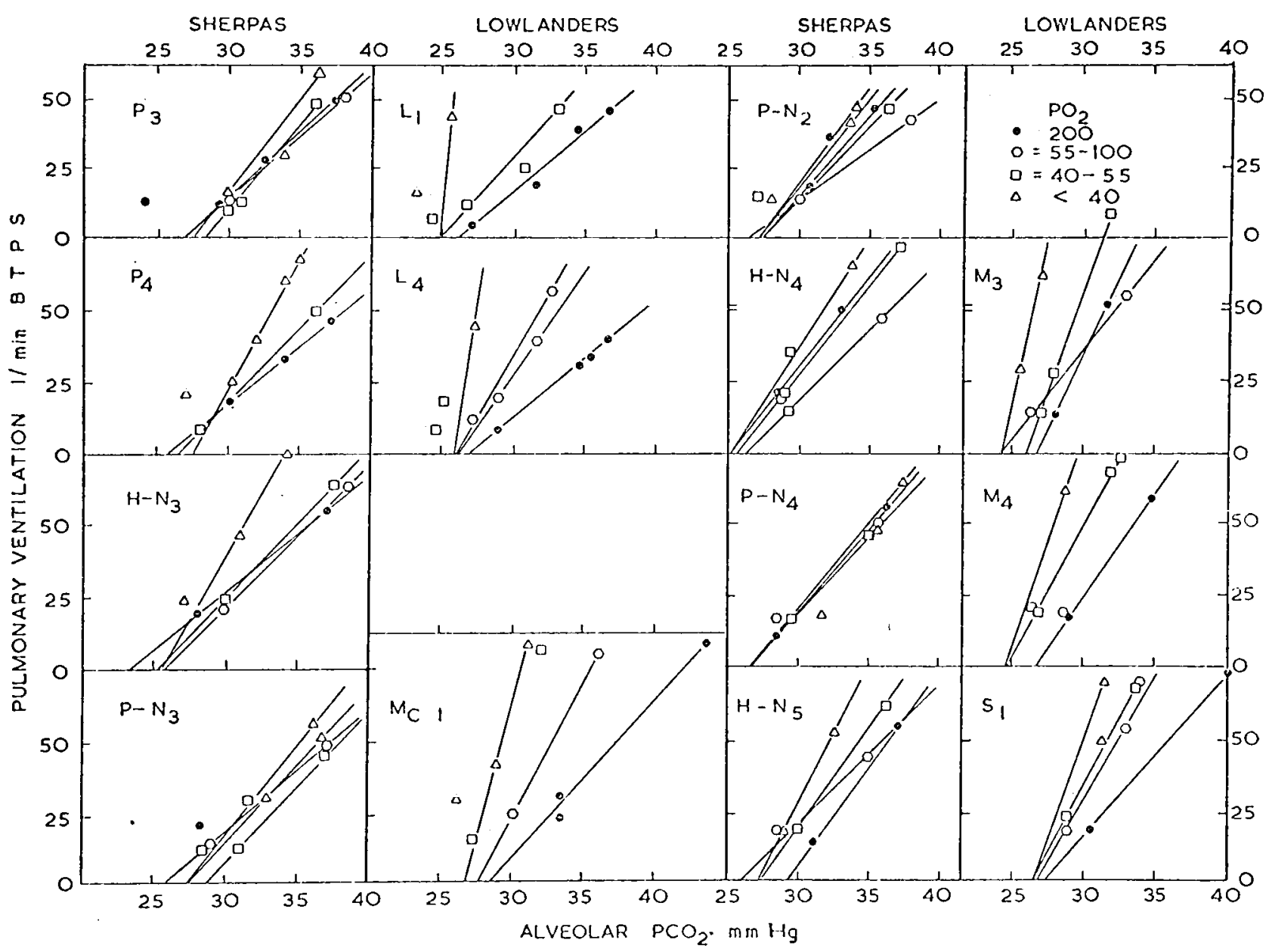

Fig. 4.9 The relation between pulmonary vantilation and $\mathrm{PACO}_{2}$ and $\mathrm{PAO}_{2}$ in Sherpas and lowlanders at an altitude of $4880 \mathrm{~m}$. Each small graph is the result of one experiment. The initials refer to individual subjects. The 1st and $3 \mathrm{ra}$ columns are Sherpa subjects, 2nd and 4 th lowlanders. Lines hase been duan through points of cqual $P$ to, whose value is indicated by symbols given in the key. 


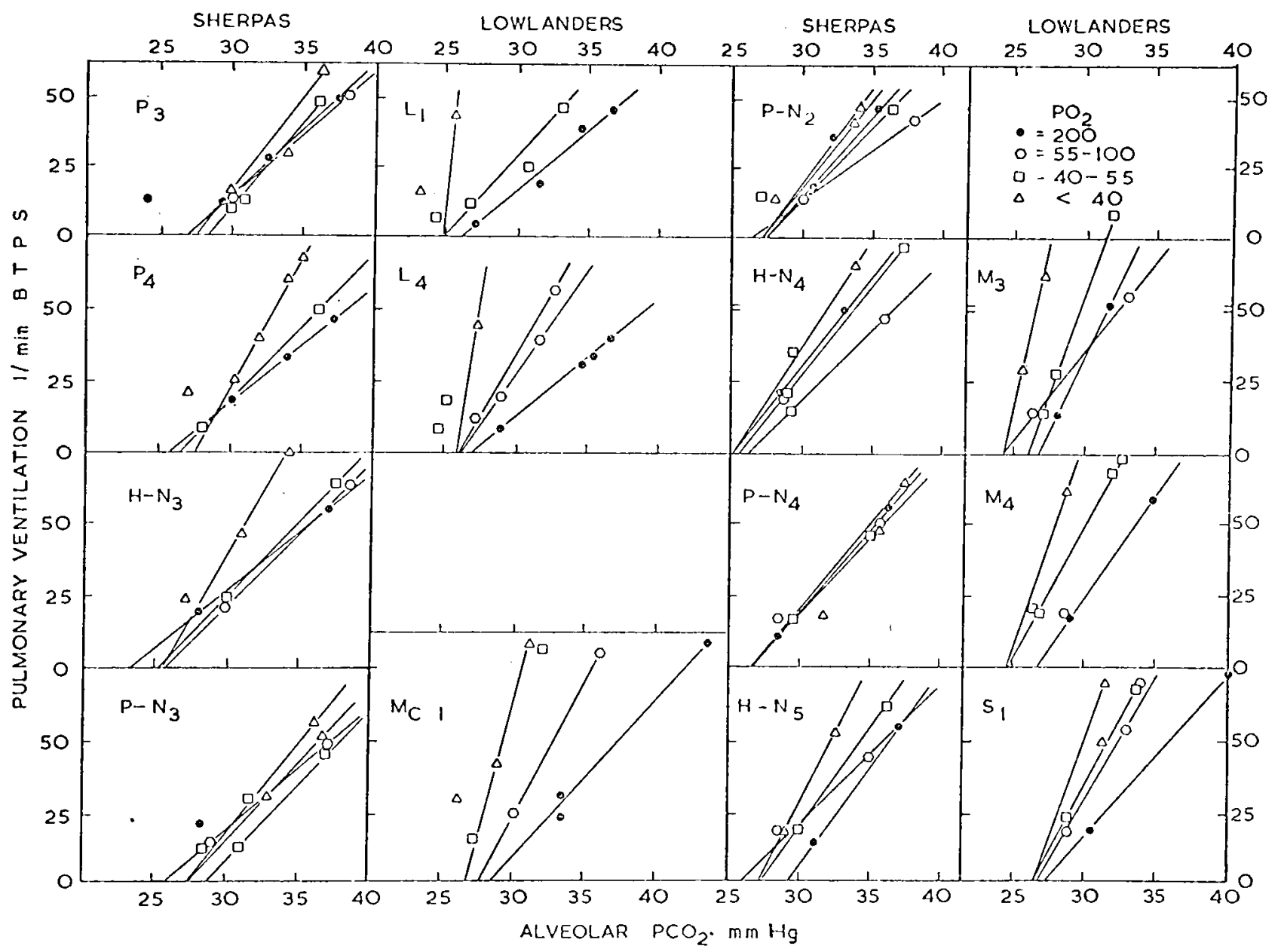

Fig. 4.1 The relation between pulmonary vantilation and $\mathrm{PACO}_{2}$ and $\mathrm{PrO}_{2}$ in Sherpas and lowlinders at an altitude of $4850 \mathrm{~m}$. Fach snall graph is the result of one experiment. The initials rufer to individual subjects. The $1 \mathrm{st}$ and 3 ra columms are Sherpa subjects, 2nd and 4 th lowlanders. Lines have ben whan through points of cqual Pao whose value is indicated by symbols gisen in the key. 


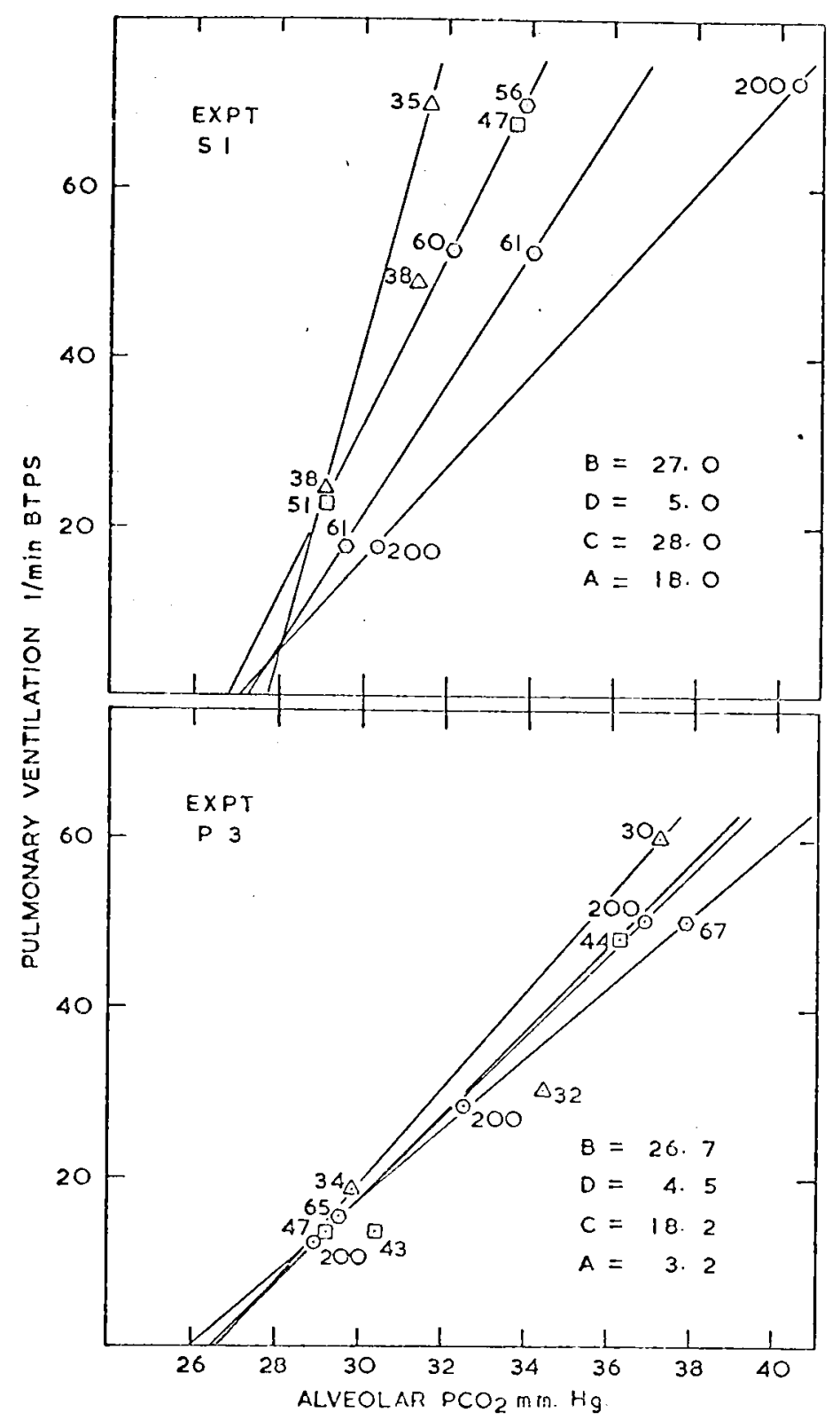

Fig. 42 The ventilatory response to $\mathrm{CO}_{2}$ and hypoxia in one experiment cach from a lowlander subject, Expt. S1, and a Sherpa subject, Expt. P3. The numbers by cach point indicate the actual PAO of that point. The calculated parameters of the ventilation control equation are given (sec text). 


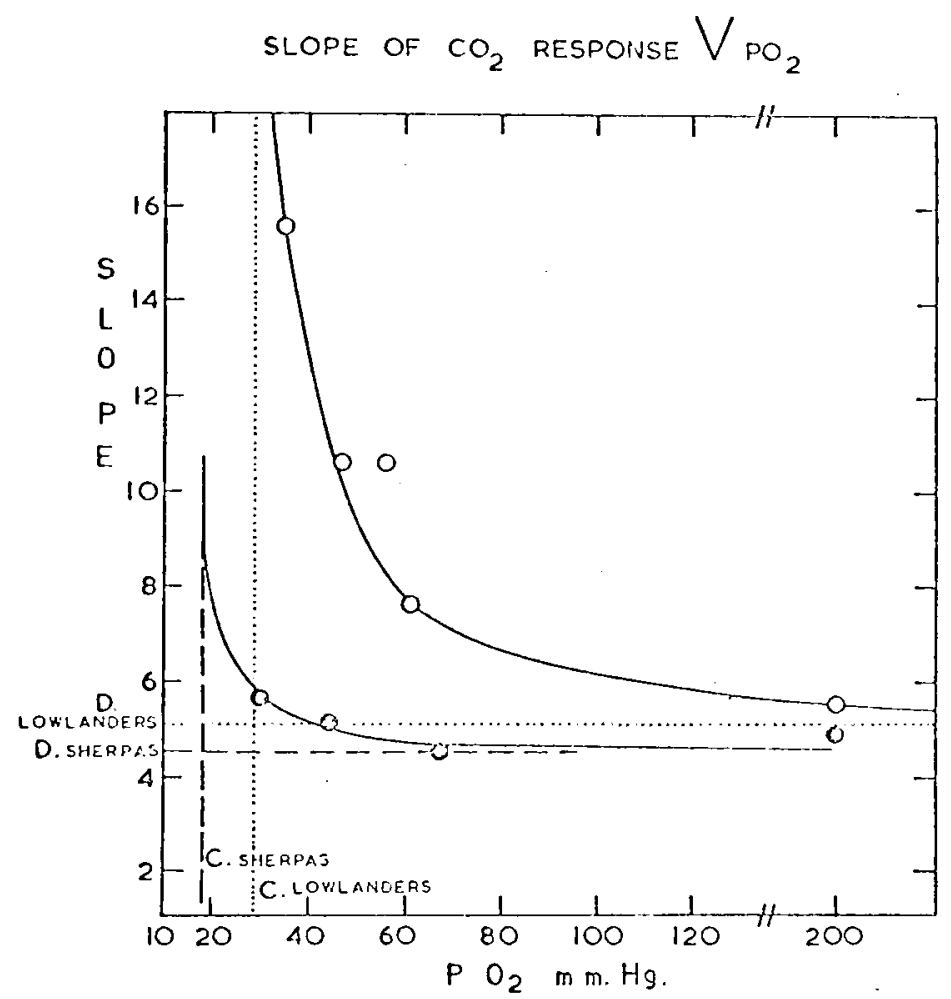

Fig.4-3The slopes of the $\mathrm{CO}_{2}$ response line at various $\mathrm{PAO}_{2}$ tensions are plotted against their respective $\mathrm{P}_{2}$ values for the two experiments shown in detail in Fig. 2. Sherpa subject 9 , lowiender $\mathrm{O}$. The calculated asymptopes $C$ and $D$ of the hyperbole are drawn for each subject. 


\section{T2EIIE 193}

Respiratory paramateis for Sherpas and Lowlanders and (last coluin) change in ventilatjon ( $V$ ) on changing from $P_{2} 200$ to $40 \mathrm{~mm} \mathrm{Hg}$ at constant $\mathrm{PCO}_{2}$ of $\mathrm{B}+\mathrm{mm} \mathrm{Hg}$

\begin{tabular}{|c|c|c|c|c|c|c|c|}
\hline Sherpas & Exp-t & $\begin{array}{l}\mathrm{B} \\
\mathrm{mm} \mathrm{Hg} \\
\mathrm{PCO}_{2}\end{array}$ & $\begin{array}{l}\mathrm{D} \\
1 / \mathrm{mIn} \\
\mathrm{Im} \mathrm{Hg} \\
\mathrm{PeO}_{2}\end{array}$ & $\begin{array}{l}\mathrm{D} \\
\mathrm{ml} / \mathrm{min} \\
\min \mathrm{Hg} / \\
\mathrm{kg}\end{array}$ & $\begin{array}{l}\mathrm{C} \\
\mathrm{mon}_{2} \mathrm{Hg}\end{array}$ & $\begin{array}{l}\text { A } \\
\text { mo }_{2} \mathrm{Hg}\end{array}$ & $\begin{array}{l}\nabla \\
\mathrm{kg} / \mathrm{min} /\end{array}$ \\
\hline Pen & 3 & 26.7 & $4_{0} 5$ & 87 & 18 & 3.2 & 39 \\
\hline Port & 4 & 27.0 & $4_{0} 1$ & 85 & 27 & 9.8 & 77 \\
\hline $\mathrm{H}, \mathrm{N}$ & 3 & 24.7 & 4.3 & 68 & 25 & $\Delta_{0} 7$ & 46 \\
\hline $\mathrm{H}_{a} \mathbb{N}_{*}$ & 4 & 25.1 & 3.3 & 51 & 20 & 20.0 & 77 \\
\hline H. N & 5 & 27.1 & 5.2 & 79 & 32 & 5.1 & 62 \\
\hline$P_{0} N$ & 2 & 26.1 & 4.0 & 67 & 22 & 5.0 & 59 \\
\hline Pol & 3 & 27.0 & 4,2 & 70 & 25 & 3.2 & 17 \\
\hline$P_{0} I T$ & 4 & - & $\infty$ & - & - & - & 17 \\
\hline Mean & & 26.2 & 43 & 72.5 & 24.2 & 7.3 & $A A$ \\
\hline \multicolumn{8}{|c|}{ Lorlanders } \\
\hline$S_{0} I_{0}$ & 1 & 25.0 & 3.6 & 65 & 30 & 802 & 196 \\
\hline S. Iso & 4 & 25.4 & 3.5 & 63 & 37 & 2600 & 890 \\
\hline $\mathrm{J}_{0} \mathrm{~S}_{0} \mathrm{M}_{0}$ & 3 & 25.2 & 5.0 & 73 & 36 & 12.0 & 605 \\
\hline$J_{0} S_{0} \mathrm{~N}$ & 4 & 25.7 & $G_{0} 0$ & 87 & 33 & 18.5 & 500 \\
\hline $\mathrm{R}_{0} \mathrm{~S}_{0}$ & 1 & $2 \% .0$ & 5.0 & 77 & 28 & $18_{0} 2$ & 210 \\
\hline$J . M C$ & 1 & 27.3 & 5.1 & 63 & 28 & 24,6 & 390 \\
\hline Moan & & 25.9 & 47 & 72.9 & 32 & 17,9 & 450 \\
\hline
\end{tabular}




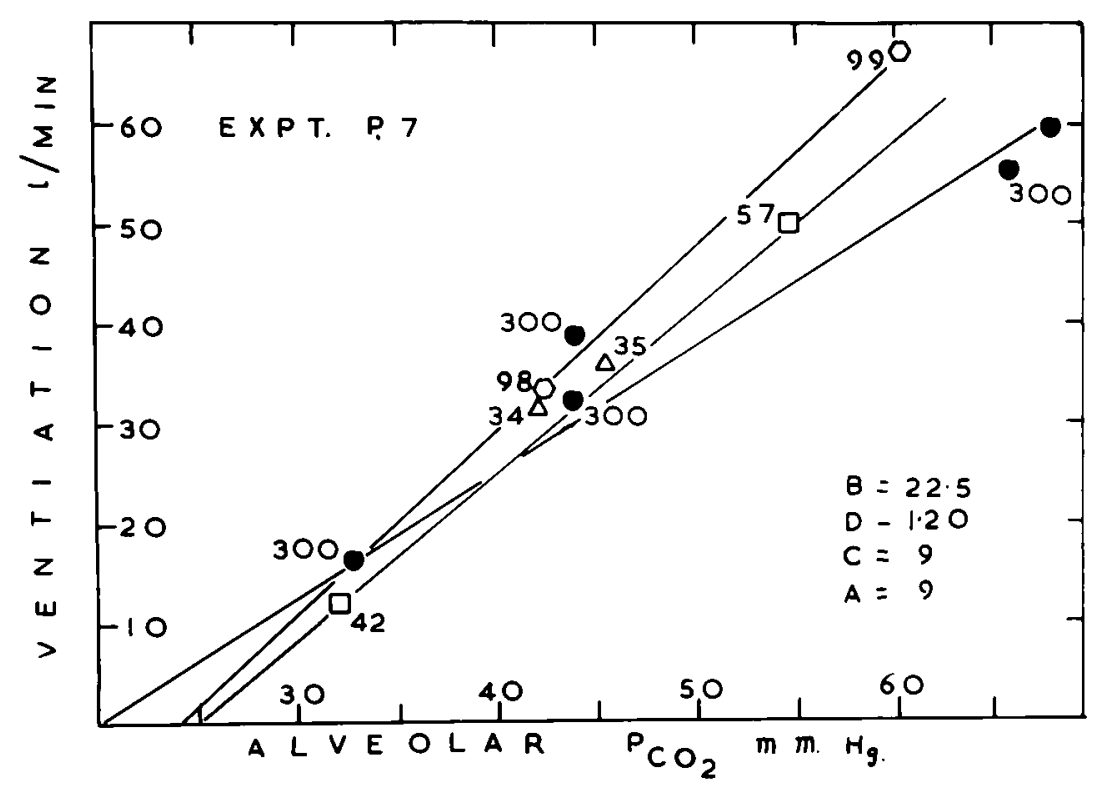

FIG. 4.4. The ventilatory response to $\mathrm{CO}_{2}$ and hypoxia in the Sherpa, subject PEN after 3 weeks at sea level. Numbers against each point indicate $\mathrm{PAO}_{2}$ of that point. 
2. The minimum slope of the fan, i.e. the slope of the $\mathrm{CO}_{2}$ response line for high $\mathrm{PO}_{2}$ is similar for the two groups.

3. The outstanding difference is the closed appearance of the fan in Sherpas, i.e. the failure of hypoxia to produce in them the vivid increase in $\mathrm{CO}_{2}$ response seen in the lowland group. This is especially seen in experiment $P-N 4$ but is noticeable in all experiments on Sherpas.

Another way of showing this difference is by plotting the slope of the $\mathrm{CO}_{2}$ response line for each $\mathrm{PO}_{2}$ against the $\mathrm{PO}_{2}$. This is done for the same two experiments in Fig. 4.3 .

\section{CALCULATED PARAMETERS}

The parameters of the equation:

$$
\nabla=D\left(\mathrm{PCO}_{2}-B\right)\left\{1+\frac{A}{\left(\mathrm{PO}_{2}-C\right)}\right\}
$$

were calculated as described in Chapter II. The results of this calculation are shown in Table 4.3 except for experiment P-N4 where it was not possible to calculate parameters.

It wi 11 be seen that between the two groups the difference in values for $B$ and for $D$ are insignificant. The slight difference in $D$ as usually expressed disappears when allowance is made for the weight of the subjects by expressing it in $\mathrm{m} 1 / \mathrm{min} / \mathrm{kg} / \mathrm{mm} \mathrm{Hg} \mathrm{PcO} 2(\mathrm{Table} \mathrm{4.3).} \mathrm{The} \mathrm{value}$ for $C$ shows a significant difference between the two groups ( $P$ 0.01), this critical minimum value for $\mathrm{PO}_{2}$ being lower in Sherpas (mean $24 \mathrm{~mm} \mathrm{Hg}$ ) than in lowlanders (mean $32 \mathrm{~mm} \mathrm{Hg}$ ). 
The reduction in $A$ in Sherpas is also striking being about 40 per cent of the lowlanders mean value. The difference is significant $(P<0.002)$

These results indicate no significant difference in $\mathrm{CO}_{2}$ parameters, but definitely and consistently low values for $\mathrm{O}_{2}$ parameters in sherpa subjects.

Another less sophisticated but more direct way of expressing this reduced hypoxic sensitivity is by calculating the change of ventilation $(\Delta \dot{V})$ on changing the $P_{A} O_{2}$ from 200 to 40 at constant $P_{A} C_{2}$ of $2 \mathrm{~mm} \mathrm{Hg}$ above B (chosen because the alveolar $\mathrm{PCO}_{2}$ is usually about this value). The result of this calculation is shown in Table 4.3 last column. It wi 11 be seen that using this index the Sherpas show only about 10 per cent of the lowlanders ventilatory response to hypoxia.

High $\mathrm{PO}_{2}$ line

In four experiments on Sherpas and one on a lowlander the point on high ventilation at high $\mathrm{Po}_{2}$ lay to the left of points at lower $\mathrm{Po}_{2}$. (See experiment P3 in $\mathrm{Fig} .4 .2$ ). This is discussed later. The $\mathrm{CO}_{2}$ response line for high oxygen often crosses over the other lines.

In a preliminary series of experiments using high $\mathrm{Po}_{2}$ mixture alone, this effect, which was more common in Sherpas, resulted in their response lines lying to the left and having a lower slope than for lowlanders. In seven such experiments, four on Sherpas and three on lowlanders, the average intercept point on the $\mathrm{CO}_{2}$ was: for Sherpas, $22.0 \mathrm{~mm} \mathrm{Hg}$ and for lowlanders, $24.1 \mathrm{~mm} \mathrm{Hg}$, whilst the slopes were 3.6 and 5.2 respectively. 
In the previous expedition (Chapter II) at 5,800 $\mathrm{m}$ we had found unexpectedly that the alveolar point breathing air lay to the left of the fan, i.e. the $\mathrm{P}_{\mathrm{A}} \mathrm{CO}_{2}$ was about $2 \mathrm{~mm} \mathrm{Hg}$ less than $B$. In this present study it was found to lie within the fan in all subjects as it does at sea level (mean value $\mathrm{P}_{A} \mathrm{CO}_{2}, 26.5 \mathrm{~mm} \mathrm{Hg}$ ). Possibly there is a limit to the extent that $B$ can be lowered by acclimatization. If this is so, it would seem to occur at an altitude of between $4,880 \mathrm{~m}$ and $5,880 \mathrm{~m}$. This coincides with the altitude that seems to be the limit for complete a titude adjustment (Pugh, 1962).

\section{Sea leve 1 experiments}

On one Sherpa subject four satisfactory inhalation experiments were carried out at sea level, on which it was possible to calculate parameters in three. The methods were approximately the same as at altitude. The subject had been at low altitude for about three weeks before experiments started. His alveolar gas tensions (Haldane - Priestly) were $\mathrm{P}_{\mathrm{A}} \mathrm{CO}_{2}$, $36.6 \mathrm{~mm} \mathrm{Hg} ; \mathrm{PAO}_{2}, 100.1 \mathrm{~mm} \mathrm{Hg}$. Other variables of interest were: hemoglobin, $13.0 \mathrm{~g}$ per cent; arterial pH, 7.425; plasma bicarbonate, $13.8 \mathrm{~m} 1$ and we conclude with respect to these parameters that he was deacclimatized. These results together with those of two sea level experiments on the Indian lowlander subject S.L. are shown in Table 4.4. One experiment on Sherpa $P$ is shown in Fig. 4.4 .

Although the data are rather meager they are quite self-consistent and show very low values for $B$ (mean $25.1 \mathrm{~mm} \mathrm{Hg}$ ) and $D(1.3$ or $25 \mathrm{ml}$ / $\mathrm{mm} \mathrm{Hg} / \mathrm{kg}$ ) that is a very low $\mathrm{CO}_{2}$ sensitivity. The oxygen parameter $\mathrm{C}$ is also very low and although the mean value for $A(12.4)$ is higher than at altitude, this is misleading because on the experiment not calculated 
TAID 4.4

Value for respiratory parameters at sea level on Sherpa and one Lowlander (Inila.) AV as in Table 4.3 .

\begin{tabular}{|c|c|c|c|c|c|c|c|}
\hline Sherpas & Expt & $\begin{array}{l}\mathrm{B} \\
\mathrm{mm} \mathrm{Hg} \\
\mathrm{PCO}_{2}\end{array}$ & $\begin{array}{l}\mathrm{D} \\
1 / \mathrm{min} \\
\mathrm{mm} \mathrm{Hg} \\
\mathrm{Pco}_{2}\end{array}$ & $\begin{array}{l}\mathrm{D} \\
\mathrm{ml} / \mathrm{min} \\
\mathrm{mm} \mathrm{Kg} / \\
\mathrm{kg}\end{array}$ & $\begin{array}{l}\mathrm{C} \\
\mathrm{mr} \mathrm{Hg} \\
\mathrm{Po}_{2}\end{array}$ & $\begin{array}{l}\mathrm{A} \\
\mathrm{mm} \mathrm{Hg} \\
\mathrm{PO}_{2}\end{array}$ & $\begin{array}{l}\Delta \dot{V} \\
\underset{\mathrm{mg}}{\mathrm{kg} / \mathrm{min}}\end{array}$ \\
\hline Pen & 7 & 22.5 & 1.20 & 23 & 9 & 9 & 19 \\
\hline Pen & 8 & 25.8 & 1.24 & 24 & 17.2 & 17 & 38 \\
\hline Pen & 9 & 22,8 & 1.42 & 27 & $16_{0} 4$ & 11.4 & 19 \\
\hline Pen & 10 & 22,5 & - & - & - & - & - \\
\hline Mean & & 24,2 & 1.3 & 25 & 14.2 & 12.4 & 25 \\
\hline
\end{tabular}

$\begin{array}{rrrrrrr}5 & 35.5 & 1.5 & 27 & 31.2 & 31.2 & 106 \\ 6 & 36.2 & 1.8 & 32 & 26.5 & 23.5 & 89\end{array}$

Mean

$35.8 \quad 1.65$

29

28.927 .5

125 
the points for $\mathrm{P} \mathrm{O}_{2}$ of from 36 to $300 \mathrm{~mm} \mathrm{Hg}$ fell on approximately the same line $(A=0)$. So the very low hypoxic sensitivity is maintained at sea level as well.

The results in subject S.L. are within the normal range except for low values for $D$.

\section{DISCUSS I ON}

\section{$\mathrm{CO}_{2}$ response}

In Chapter II it was shown that the respiratory response to $\mathrm{CO}_{2}$ was markedly increased in man on going first to altitude in that both the intercept of the $\mathrm{CO}_{2}$ response line (B) was lowered and its slope (D) was increased. But Chiodi (1957) found that in long term Andean residents this increase in $\mathrm{CO}_{2}$ sensitivity was largely lost and that the slope of the $\mathrm{CO}_{2}$ response line approached sea level values or even became lower although the intercept was similar. We therefore expected to find a definite difference in the parameter $D$ between our groups.

In our preliminary studies there was a smal1 but definite difference in the slope of the $\mathrm{CO}_{2}$ response line between our groups using a high oxygen mixture only. When we later carried out fuller experiments using various oxygen mixtures we found that the Sherpas more often showed the wel1-known "cross-over" effect on high oxygen described by Cunningham, Patrick and Lloyd (1964). That is while the lower $\mathrm{Po}_{2}$ lines converge to a single point on the $\mathrm{CO}_{2}$ axis, the line for high oxygen crosses over this fan to a lower intercept. So that on changing from a $\mathrm{Po}_{2}$ of say 100 to 200 at low $\mathrm{CO}_{2}$ values the ventilation rises, while at high $\mathrm{CO}_{2}$ values the ventilation may remain unchanged or fall slightly. This is well seen in experiment H-N3 (Fig. 4.1). Sometimes this paradoxical effect of 
high oxygen continues up to high $\mathrm{CO}_{2}$ values in which case the response line is found to lie entirely to the left of that for a lower $\mathrm{PO}_{2}$. This was found in four experiments on Sherpas, e.g. experiment P-N2 and H-N4 (Fig. 4.1) and in experiments on Sherpa $P$ at sea level. This effect is presumably due to a reduction in cerebral blood flow with high $\mathrm{PaO}_{2}$ resulting in a higher tissue $\mathrm{PCO}_{2}$. Why this effect should be more marked in Sherpas is not clear. It may merely happen at lower $\mathrm{O}_{2}$ values, i.e. between $\mathrm{PO}_{2} 100$ to 200 whereas Cunningham et al. found it to occur mainly above $\mathrm{PO}_{2} 210$ in lowlanders at sea level. However, in calculating $\mathrm{D}$ from the full experiments the effect of such cross-over is eliminated and our conclusion is that with respect to $\mathrm{CO}_{2}$ parameters there is very little difference between our two groups. This is in accord with the results of Severinghaus, Bainton and Carcelen (1966) in Andean residents.

But it may well be that Sherpas respond differently from Andean natives. Chiodi (1957) reported in the same paper the finding that his subjects had higher resting $\mathrm{P}_{A} \mathrm{CO}_{2}$ and lower $\mathrm{P}_{A} \mathrm{O}_{2}$ than acclimatized lowlanders, and when plotted on the $\mathrm{O}_{2}-\mathrm{CO}_{2}$ diagram of Rahn and Otis (1949) clustered around the line for unacclimatized man. We found that the alveolar gas tensions for our two groups were less divergent though there was a significant difference (mean $\mathrm{P}_{A} \mathrm{CO}_{2}$ for lowlanders was $25.9 \pm 0.60 \mathrm{~mm} \mathrm{Hg}$; for Sherpas $28.6 \pm 0.42 \mathrm{~mm} \mathrm{Hg} ; \mathrm{P}<0.002$ ) and both fell close to the line for acclimatized man.

It is interesting that on descending to sea level the one Sherpa subject studied had very low values for both $D$ and $B$, which at $1.31 / \mathrm{min} /$ $\mathrm{mm} \mathrm{Hg}$ and $25.1 \mathrm{~mm} \mathrm{Hg}$ are well below the normal value given by Cunningham 
et al. (1964) of $3.9+1.4$ and $37.7+2.8$ respectively. But Sorensen, Severinghaus, Cruz, Whayne and Carcelen (1964) did not find low values in Andean high altitude natives resident at sea level.

The averaged results from both expeditions for $D$ in $\mathrm{m} 1 / \mathrm{min} / \mathrm{mm} \mathrm{Hg} / \mathrm{kg}$ are:

$\begin{array}{llll}\text { at sea leve } 1 & & \text { and at altitude } & \\ \text { Sherpa } & 25 & \text { lowlanders }(4,880 \mathrm{~m}) & 73 \\ \text { Indian lowlander } & 29 & \text { Sherpas }(4,880 \mathrm{~m}) & 72 \\ \text { European lowlander } & 52 & \text { Lowlanders }(5,800 \mathrm{~m}) & 107\end{array}$

Hypoxic response

There has been considerable debate about the effect of acclimatization on the ventilatory response to hypoxia in both newcomers and in residents at high altitude.

Earlier work has mainly centered on observing the reduction in ventilation on breathing oxygen enriched mixtures (including Haldane and Priest1y, 1935; Chapin, 1954; and Chiodi, 1957). The results showed a wide range of variation. This method is theoretically unsatisfactory as a measure of hypoxic sensitivity, since any reduction in ventilation results in a rise of $\mathrm{PaCO}_{2}$ and the new steady state level of ventilation is due as much to sensitivity to $\mathrm{CO}_{2}$ as to hypoxia. The single breath of oxygen technique of Dejours, et al. (1959) overcomes this and has been used at altitude. Cerete11i (quoted by Dejours, 1963) used it on one subject, a lowlander well acclimatized to $5,000 \mathrm{~m}$ and showed a very definite response. Lefrancois, Gautier, and Pasquis (1967) more recently reported results on natives to high altitude and showed that their response to a single breath of oxygen is about half that of lowlanders. But Chiodi (1963) found the single breath method to be no improvement over continuous inhalation. 
Since the work of Nielsen and Smith (1951), Cormack, Cunningham and Gee (1957) and Lloyd et a1. (1958), we have come to think of hypoxia acting on the $\mathrm{CO}_{2}$ feed back system by enhancing its sensitivity. Therefore, the most satisfactory way of measuring the hypoxic response is to plot the $\mathrm{CO}_{2}$ response at various levels of hypoxia. The increasing slope of the $\mathrm{CO}_{2}$ response lines thus found is a measure of the hypoxic stimulus, parameter $A$. On the previous expedition (Chapter II) we found no significant change in the oxygen parameters $A$ and $C$ between lowlanders at sea leve 1 and when acclimatized to altitude though there was a suggestion of some slight increase in $A$. (Three subjects showed an increase and one a decrease.)

Now we find a very definite difference between Sherpas and lowlanders at altitude. The lowlanders data though a little meager agrees we 11 with results from the previous expedition and with values given by Cunningham et a 1. (1964).

The parameter $A$ is found to be consistently much reduced in Sherpas. This result is in accord with Severinghaus et a 1. (1966) though in their results the $\mathrm{CO}_{2}$ response lines were too close together to permit the calculation of parameters (Severinghaus, personal communication) such as we found in experiment P-N4 (Fig. 1).

The relative lack of hypoxic sensitivity is not related to differences in hematocrit as might be inferred from the work of Severinghaus et a 1. (1966), since in our subjects hemoglobin values were the same for our two groups at altitude (Sherpas, $19.0 \mathrm{gm}$ per cent; lowlanders, $19.3 \mathrm{gm}$ per cent).

In the study on muscular work (Chapter $V$ ) we found that whereas in lowlanders the addition of oxygen to the inspired air during exercise 
resulted in a marked reduction in ventilation; the same increase in $\mathrm{P}_{\mathrm{I}} \mathrm{O}_{2}$ in Sherpas had a small effect on ventilation. Conversely, a further reduction of $\mathrm{P}_{I} \mathrm{O}_{2}$ in the lowland subject resulted in a great increase in ventilation; in the Sherpas it produced only a slight rise.

Severinghaus and Carcelen (1964) showed that the acid-base situation in cerebrospinal fluid of Andean residents did not differ from that of newly arrived lowlanders. They argued, therefore, that the lower ventilation found in these residents must be due to reduced peripheral chemoreceptor drive (assuming the $\mathrm{CO}_{2}$ drive to be mediated through $\mathrm{H}^{+}$concentration in (SF). Our findings in this respect were similar except that our lowland subjects actually had slightly higher CSF pH values (mean: lowlanders, 7.363; Sherpas, 7.328) (Chapter VI) suggesting a greater respiratory drive in Sherpas due to $\mathrm{CSF} \mathrm{H}^{+}$concentration and, therefore, even less due to peripheral chemoreceptors.

Dr. Lahiri collected some data on breath-holding during the two expeditions (unpublished) which also demonstrated this relative insensitivity in Sherpas to respiratory stimuli. Taking his own maximum voluntary apnoea time at various altitudes as 100 per cent, Sherpa $P$ had times of 188 per cent at sea level, 160 per cent at 4,880 m and 140 per cent at $5,880 \mathrm{~m}$.

Thus all these separate lines of evidence support the contention that residents at high altitude have a greatly reduced hypoxic ventilatory response.

High altitude residents at sea level

The one Sherpa studied at sea level retained his hypoxic insensitivity in the four experiments performed on him, and while this finding by itself 
is of uncertain significance, it has since been supported by Sorensen, Severinghaus, Cruz, Whayne and Carcelen (1967) in Andean high altitude residents at sea leve 1 and later by Sorensen and Severinghaus (1967) in patients born with cyanotic heart disease whose condition had been corrected. Both these groups of people had been subject to chronic hypoxia from birth but had enjoyed normoxia for a number of years before being studied. They all showed a relative insensitivity to hypoxia. Conversely, people native to low altitude retained their hypoxic response even though they had been at altitude for years (Sorensen et a1., 1967). The findings in the congenital heart disease group is of special interest as it makes it unlikely that this hypoxic insensitivity can be attributed to genetic causes.

Parameter C

This parameter, the theoretical $\mathrm{PO}_{2}$ at which $\mathrm{CO}_{2}$ sensitivity becomes infinite is of uncertain significance. It does not necessarily measure the same biological function as $A$, since in noradrenaline infusion $A$ is increased independently of C (Cunningham, Hey, Patrick and Lloyd, 1963). This value is also smaller in Sherpas at altitude and seems to remain low on coming down to sea level. Possibly it indicates an increased tolerance to extreme hypoxia. On one run at sea level in the Sherpa subject, due to an error in making up the gas mixture, a lower $\mathrm{P}_{\mathrm{I}} \mathrm{O}_{2}$ than intended was given resulting in a $\mathrm{P}_{\mathrm{A}} \mathrm{O}_{2}$ of $26.5 \mathrm{~mm} \mathrm{Hg}$. The subject became uncomfortable with slight shivering by the time the mixture was switched off after six minutes but showed no irrational behavior or clouding of consciousness as is normally seen in unacclimatized subjects at $P_{A} O_{2}$ 35-40. 


\section{CONC LUS I ON}

The important difference in ventilatory control between lowlanders and high altitude residents is the very low hypoxic sensitivity of the latter. We were unable to demonstrate any difference in $\mathrm{CO}_{2}$ sensitivity between the two groups.

This hypoxic insensitivity persists at sea level apparently for years.

The question of its significance in oxygen supply and acid-base regulation wi 11 be discussed in Chapter VI. 
REFERENCES

Chapter IV

Chiodi, H. (1957). Respiratory adaptations to chronic high altitude hypoxia. J. App1. Physiol. 10,81-87.

Chiodi, H. (1963). Respiratory adaptation to high altitude; in The Regulation of Human Respiration, edited b、 D. J. C. Cunningham and B. B. Lloyd. Oxford: Blackwe11, pp. 363-378.

Cormack, K. S., D. J. C. Cunningham and J. B. L. Gee (1957). The effect of carbon dioxide on the respiratory response to want of oxygen in man. Quart. J. Exp. Physio1. 42; 303-314.

Cunningham, D. J. C., E. N. Hey, J. M. Patrick and B. B. Lloyd (1963). The effect of noradrenaline infusion on the relation between pulmonary ventilation and alveolar $\mathrm{Po}_{2}$ and $\mathrm{PCO}_{2}$ in man. Ann. N. Y. Acad. Sci. 109, 756-770.

Cunningham, D. J. C., J. M. Patrick and B. B. Lloyd (1964). The respiratory response of man to hypoxia; in Oxygen in the Anima 1 Organism, edited by F. Dickenson and E. Nei 1. Oxford: Pergamon Press, pp. 277-291.

Dejours, P., F. Girard, Y. Labrousse and A. Teillac (1959). Etude de la régulation de la ventilation de repos chez l'Homme en haute altitude. Rev. Franc. Etudes C1in. Bio1. 4, 115-127.

Dejours, P. (1963). Discussion in: The Regulation of Human Respiration. Edited by D. J. C. Cunningham and B. B. Lloyd. Oxford, Blackwe11 p. 447 .

Fitzgerald, M. P. (1913). The changes in the breathing and the blood at various high altitudes. Phil. Trans. Roy. Soc. London, Ser. B. $203,351-371$.

Kellogg, R. H., N. Pace, E. R. Archibald and B. E. Vaughan (1957). Respiratory response to inspired $\mathrm{CO}_{2}$ during acclimatization to an altitude of $12,470 \mathrm{ft}$. J. Appl. Physio1. 11, 65-71.

Lefrancois, R., H. Gautier and P. Pasquis (1967). Ventilatory oxygen drive in high altitude natives: in Proceedings of the XXIII International Congress of Physiological Sciences, Tokyo. 
Lloyd, B. B., M. G. M. Jukes and D. J. C. Cunningham (1958). The relationship between alveolar oxygen pressure and the respiratory response to carbon dioxide in man. Quart. J. Exp. Physio1. 43, 214-227.

Nielsen, M. and $H$. Smith (1952). Studies on the regulation of respiration in acute hypoxia. Acta Physio1. Scand. 24, 293-313.

Rahn, H., R. C. Stroud, S. M. Tenney and J. C. Mithoefer (1953). Adaptation to high altitude: Respiratory response to $\mathrm{CO}_{2}$ and $\mathrm{O}_{2}$. J. Appl. Physio1. 6, 158-162.

Severinghaus, J.W. and A. Carcelen (1964). Cerebrospinal fluid in man native to high altitude. J. Appl. Physiol. 19, 319-321.

Severinghaus, J.W., C. R. Bainton and A. Carcelen (1966). Respiratory insensitivity to hypoxia in chronically hypoxic man. Resp. Physiol. $1,308-334$.

Sørensen, S. C., J. W. Severinghaus, J. Cruz, T. F. Whayne, Jr. and A. Carcelen (1967). Respiratory sensitivity to hypoxia during and after chronic hypoxia (abstract). Fed. Proc. 26, 665.

Sфrensen, S. C. and J. W. Severinghaus (1967). Respiratory insensitivity to hypoxia persisting after correction of Fallot's tetralogy (abstract). The Physiologist 10, 309. 


\author{
C H A P T E R V \\ VENTILATI ON DURING EXERCISE IN SHERPAS
}

\title{
INTR ODUCTI ON
}

One of the most obvious differences in response to altitude between Sherpas and even we 11 -acclimatized lowlanders is the apparent freedom from dyspnoea of the Sherpas when climbing. The impression is that to do the same degree of work, they require less ventilation. In 1962 on one Sherpa examined, this was confirmed (Pugh et a1., 1964). On the second School-House expedition in 1964 (Chapter I) we had the opportunity to examine this more fully as a companion study to the inhalation experiments at rest described in the previous chapter.

We also performed some experiments in which the subject inhaled oxygen-enriched or -reduced gas mixtures to determine the effect of reducing or increasing the hypoxic drive.

\section{$\underline{\text { SUB JECTS }}$}

These were the same as in the companion study. Their characteristics are given in Table 4.1 .

\section{METHODS AND PROCEDURE}

Measurements were begun not less than two hours after a light meal. Most exercise studies were done on a bicycle ergometer similar to that used on the previous expedition, made to our order in India. But in view of the fact that Sherpas are unaccustomed to bicycling, we also did some 
studies during climbing up a slope of about 30 degrees with and without a $19 \mathrm{~kg}$ load, at various speeds. The Sherpas after considerable practice learned to bicycle with varying degrees of success. A11 four subjects could manage light and moderate work by the second month but only two could keep their feet on the pedals when working at maximum rate.

On the bicycle ergometer or on the test climbing slope the subjects breathed through a valve of low resistance, and the expired air was collected for a timed period in a light plastic Douglas bag of low $\mathrm{O}_{2}$ and $\mathrm{CO}_{2}$ permeability. The volume and temperature of the expired air and the ambient pressure were noted. In experiments with gas mixtures other than air, the subject breathed from a 1,000 1iter bag. When end-tidal samples were collected, a Rahn-0tis sampler was attached to the breathing valve, and the sample was drawn at a rate of about $100 \mathrm{ml} / \mathrm{min}$ by water displacement over a series of Barcroft sampling tubes filled with mercury. These samples collected by mercury displacement were coincident with the expired air collection. End-tidal samples thus lost were taken into account in calculating the expired volume of air. For the recovery experiments, the subjects pedalled at the highest work rate they could accomplish. After $2.5 \mathrm{~min}$, expired air was collected for a timed period of half a minute, at the end of which the subject stopped working but remained seated at the ergometer. Expired air was then collected for the following $5 \mathrm{~min}$ in one bag, and then for the subsequent $10 \mathrm{~min}$ in a second bag. Blood samples for the estimation of lactate were taken from the finger tip of the warm hand at 2-3 min, 9-10 min, and 15-16 min after stopping work. Prior to this type of experiment resting oxygen consumption on the bicycle was determined, and blood samples were collected for resting lactate. 
Respiratory gas samples were analyzed using a Lloyd-Haldane gas analysis apparatus. Heart rates were recorded with a Cambridge Transite 111 electrocardiograph, usually during the last half minute of work on the bicycle and often continuing for a few seconds after stopping. Blood pH was determined with an Astrup capillary microelectrode and Radiometer M4 pH meter at $37^{\circ} \mathrm{C}$. Phosphate buffers of 6.840 and 7.384 at $37^{\circ} \mathrm{C}$ served as the primary standards and for testing electrode sensitivity over this range. Except for arterial blood, al1 samples for blood pH were obtained from the finger tip of the warmed hand. These samples are known to be similar in pH to arterial blood (Siggard-Andersen et a1., 1960). No correction for the effect of polycythemia in lowering plasma pH was made (Severinghaus, Stupfel and Bradley, 1956).

In one series of experiments involving the breathing of air and of pure oxygen by a Sherpa and a lowlander, arterial samples were collected anaerobically to determine the effects of oxygen inhalation on arterial saturation and arterial $\mathrm{O}_{2}$ saturation and $\mathrm{pH}$ at rest and during exercise. Blood pH was determined immediately and blood gases were estimated within $2 \mathrm{hr}$ of their collection by the volumetric method of Haldane (Cunningham, Shaw, Lahiri and Lloyd, 1961).

For lactate determinations, $0.1 \mathrm{ml}$ blood samples were placed in $4.9 \mathrm{~m} 1$ of normal saline, to which was added $5 \mathrm{~m} 1$ of 10 per cent trichloroacetic acid. The samples were filtered, the filtrates were placed in air tight containers, and stored in the frozen state for shipment to Calcutta where they were analyzed by a modification of a method of Barker and Summerson (1941). 
RESULTS

The data are presented in Tables 5.1-5.3 and shown graphically in Figs . $5 \cdot 1-5 \cdot 3$

Oxygen uptake and work

Fig. 5.1 shows steady-state relation between oxygen uptake (average of each subject) and work rate in Sherpas and lowlanders at $4,880 \mathrm{~m}$ and at sea leve1. This relation is linear and similar in Sherpas and lowlanders, and it is independent of altitude.

Oxygen uptake and pulmonary ventilation

Fig. 5.2 shows the relation of ventilation (BTPS) to oxygen uptake, both in climbing and ergometer experiments at high altitude. At a given work level, Sherpa subjects ventilated relatively less than the acclimatized lowlanders and their rate of increase was smaller, particularly in the higher range of oxygen uptake. The mean respiratory rates for a given work leve1 were similar in both groups. The mean rate was 22 at rest and 30,42 , and 50 , respectively for work levels of 475,900 , and 1,265 $\mathrm{kg}-\mathrm{m} / \mathrm{min}$.

Ventilation in acute exposure to low and high $\mathrm{PO}_{2}$ (Table 5.3)

On inhalation of sea level $\mathrm{P}_{\mathrm{I}_{2}}$ at high altitude, pulmonary ventilation during exercise decreased considerably more in the lowlanders than in the Sherpa subjects. Ventilation in the lowlanders was reduced by 33 per cent on oxygen inhalation up to an oxygen uptake of $1 \mathrm{l} / \mathrm{min}$, falling further at higher work rates; the greatest reduction amounting to 48 per cent. This progressive fall in ventilation possibly corresponds to the removal of increasing arterial hypoxaemia that occurs 
TABLE 51. Results of work experiments at 4,880 m

\begin{tabular}{|c|c|c|c|c|c|}
\hline Subj & $\begin{array}{l}\text { No. of } \\
\text { Obscrv }\end{array}$ & $\underset{\text { liters/min }}{\dot{V}_{\text {LTPS }}}$ & $\begin{array}{c}\dot{V}_{02} \\
\text { liters/min }\end{array}$ & $\mathbf{R}$ & $\begin{array}{l}\text { Heart Ratc, } \\
\text { beats/min }\end{array}$ \\
\hline \multicolumn{6}{|c|}{ Rest, sitting on ergometer } \\
\hline \multicolumn{6}{|l|}{ Lowlanders } \\
\hline$S L$ & 2 & 10.6 & 0.227 & 0.77 & 99 \\
\hline$J S M$ & 1 & 11.6 & 0.270 & 0.84 & 72 \\
\hline \multicolumn{6}{|c|}{ Work rate, $475 \mathrm{~kg}-\mathrm{m} / \mathrm{min}$} \\
\hline$S L$ & 8 & 59.9 & 1.205 & 0.97 & 140 \\
\hline$J S M$ & 4 & 44.2 & 1.144 & 0.94 & 113 \\
\hline \multicolumn{6}{|c|}{ Work rate, $900 \mathrm{~kg}-\mathrm{m} / \mathrm{min}$} \\
\hline$S L$ & 7 & 87.5 & 1.673 & 1.09 & 166 \\
\hline$J S M$ & 4 & 86.5 & 1.959 & 0.99 & 141 \\
\hline \multicolumn{6}{|c|}{ Work rate, $1,265 \mathrm{~kg}-\mathrm{m} / \mathrm{min}$} \\
\hline$S L$ & 5 & 98.4 & 1.797 & 1.20 & 165 \\
\hline$J S M$ & 4 & 148.0 & 2.566 & 1.14 & 146 \\
\hline \multicolumn{6}{|c|}{ Rest, sitting on ergometer } \\
\hline Sherpas & & & & & \\
\hline$P E N$ & 2 & 12.9 & 0.288 & 0.97 & 67 \\
\hline$P N$ & 1 & 22.5 & 0.277 & 1.00 & 63 \\
\hline$H N$ & 1 & 13.6 & 0.296 & 1.02 & 69 \\
\hline$L T$ & 1 & 26.4 & 0.365 & 0.99 & 62 \\
\hline \multicolumn{6}{|c|}{ Work rate, $475 \mathrm{~kg}-\mathrm{m} / \mathrm{min}$} \\
\hline$P E N$ & 7 & 42.4 & 1.134 & 0.95 & 138 \\
\hline$P N$ & 5 & 43.1 & 1.216 & 0.92 & 131 \\
\hline$H N$ & 7 & 47.7 & 1.352 & 0.92 & 139 \\
\hline$L T$ & 5 & 57.1 & 1.274 & 1.05 & 112 \\
\hline \multicolumn{6}{|c|}{ Work rate, $900 \mathrm{~kg}-\mathrm{m} / \mathrm{min}$} \\
\hline$P E N$ & 7 & 76.0 & 1.831 & 1.06 & 176 \\
\hline$P N$ & 4 & 98.8 & 2.188 & 1.04 & 181 \\
\hline$H N$ & 7 & 77.1 & 2.148 & 1.06 & 172 \\
\hline$L T$ & 5 & 108.8 & 2.118 & 1.05 & 143 \\
\hline \multicolumn{6}{|c|}{ Work rate, $1,265 \mathrm{~kg}-\mathrm{m} / \mathrm{min}$} \\
\hline$P E N$ & 2 & 109.4 & 2.550 & 1.08 & 198 \\
\hline$P N$ & 4 & 118.7 & 2.763 & 1.09 & 195 \\
\hline$H N$ & 1 & 116.3 & 2.713 & 1.07 & 154 \\
\hline$L T$ & 1 & & & & 150 \\
\hline
\end{tabular}


TABLE5.1. Results of work experiments at $4,880 \mathrm{~m}$

\begin{tabular}{|c|c|c|c|c|c|}
\hline Subj & $\begin{array}{l}\text { No. of } \\
\text { Observ }\end{array}$ & $\begin{array}{c}\text { VBrrs, } \\
\text { Iiters/min }\end{array}$ & $\begin{array}{l}\text { Voo, } \\
\text { liters } / \mathrm{min}\end{array}$ & $\mathbf{R}$ & $\begin{array}{l}\text { Heart Ratc, } \\
\text { beats/min }\end{array}$ \\
\hline \multicolumn{6}{|c|}{ Rest, sitting on ergometer } \\
\hline \multicolumn{6}{|c|}{ Lowlanders } \\
\hline$S L$ & 2 & 10.6 & 0.227 & 0.77 & 99 \\
\hline$J S M$ & 1 & 11.6 & 0.270 & 0.84 & 72 \\
\hline \multicolumn{6}{|c|}{ Work rate, $475 \mathrm{~kg}-\mathrm{m} / \mathrm{min}$} \\
\hline$S L$ & 8 & 59.9 & 1.205 & 0.97 & 140 \\
\hline$J S M$ & 4 & 44.2 & 1.144 & 0.94 & 113 \\
\hline \multicolumn{6}{|c|}{ Work rate, $900 \mathrm{~kg}-\mathrm{m} / \mathrm{min}$} \\
\hline$S L$ & 7 & 87.5 & 1.673 & 1.09 & 166 \\
\hline$J S M$ & 4 & 86.5 & 1.959 & 0.99 & 141 \\
\hline \multicolumn{6}{|c|}{ Work rate, $1,265 \mathrm{~kg}-\mathrm{m} / \mathrm{min}$} \\
\hline$S L$ & 5 & 98.4 & 1.797 & 1.20 & 165 \\
\hline$J S M$ & 4 & 148.0 & 2.566 & 1.14 & 146 \\
\hline \multicolumn{6}{|c|}{ Rest, sitting on ergometer } \\
\hline Sherpas & & & & & \\
\hline$P E N$ & 2 & 12.9 & 0.288 & 0.97 & 67 \\
\hline$P N$ & 1 & 22.5 & 0.277 & 1.00 & 63 \\
\hline$H N$ & 1 & 13.6 & 0.296 & 1.02 & 69 \\
\hline$L T$ & 1 & 26.4 & 0.365 & 0.99 & 62 \\
\hline \multicolumn{6}{|c|}{ Work rate, $475 \mathrm{~kg}-\mathrm{m} / \mathrm{min}$} \\
\hline$P E N$ & 7 & 42.4 & 1.134 & 0.95 & 138 \\
\hline$P N$ & 5 & 43.1 & 1.216 & 0.92 & 131 \\
\hline$H N$ & 7 & 47.7 & 1.352 & 0.92 & 139 \\
\hline$L T$ & 5 & 57.1 & 1.274 & 1.05 & 112 \\
\hline \multicolumn{6}{|c|}{ Work rate, $900 \mathrm{~kg}-\mathrm{m} / \mathrm{min}$} \\
\hline$P E N$ & 7 & 76.0 & 1.831 & 1.06 & 176 \\
\hline$P N$ & 4 & 98.8 & 2.188 & 1.04 & 181 \\
\hline$H N$ & 7 & 77.1 & 2.148 & 1.06 & 172 \\
\hline$L T$ & 5 & 108.8 & 2.118 & 1.05 & 143 \\
\hline \multicolumn{6}{|c|}{ Work rate, $1,265 \mathrm{~kg}-\mathrm{m} / \mathrm{min}$} \\
\hline$P E N$ & 2 & 109.4 & 2.550 & 1.08 & 198 \\
\hline$P N$ & 4 & 118.7 & 2.763 & 1.09 & 195 \\
\hline$H N$ & 1 & 116.3 & 2.713 & 1.07 & 154 \\
\hline$L T$ & 1 & & & & 150 \\
\hline
\end{tabular}


Table 50\%. Results of climbing experiments on a mountain slope at $4880 \mathrm{~m} . \mathrm{P}_{\mathrm{B}} 422-4 \mathrm{~mm} \mathrm{Hg}$.

Subject:

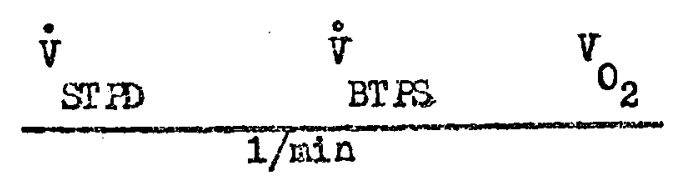

Moderate rate

$\begin{array}{llllll}\text { Lowlander } & \text { JSM } & 16.6 & 37.3 & 0.882 & 0.87 \\ \text { Sherpa } & \text { FiN } & 12.8 & 29.6 & 0.802 & 0.80 \\ & \text { EN } & 17.6 & 40.5 & 1.188 & 0.83\end{array}$

Mozezate rate with logd on bagk (19 kg)

Lowlender JSM $\quad 23,0, \quad 53,0 \quad 1.316 \quad 0.91$

$\begin{array}{llllll}\text { Sherpa FEN } & 12.8 & 29.2 & 0.856 & 0.87\end{array}$

$\begin{array}{lllll} & 17.6 & 40.6 & 1.126 & 0.95 \\ \text { HN } & 23.1 & 53.3 & 1.510 & 0.95\end{array}$

Haxirum rate of clinb wibh lad (19 $\mathrm{kg})$

$\begin{array}{llllll}\text { Loilander } & \text { JSM } & 39.5 & 90.1 & 1.663 & 1.04 \\ \text { Shorpa } & \text { Rai } & 35.8 & 82.7 & 1.637 & 1.22 . \\ & \text { HN } & 42.7 & 98.6 & 3.290 & 1.160\end{array}$




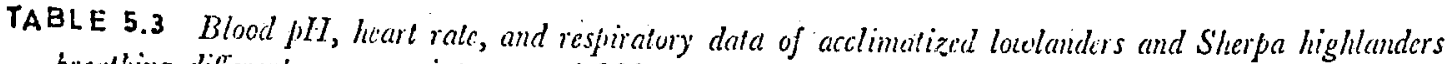
breulhing differcnt oxygen mixtures at 4,880 m measured in a single session

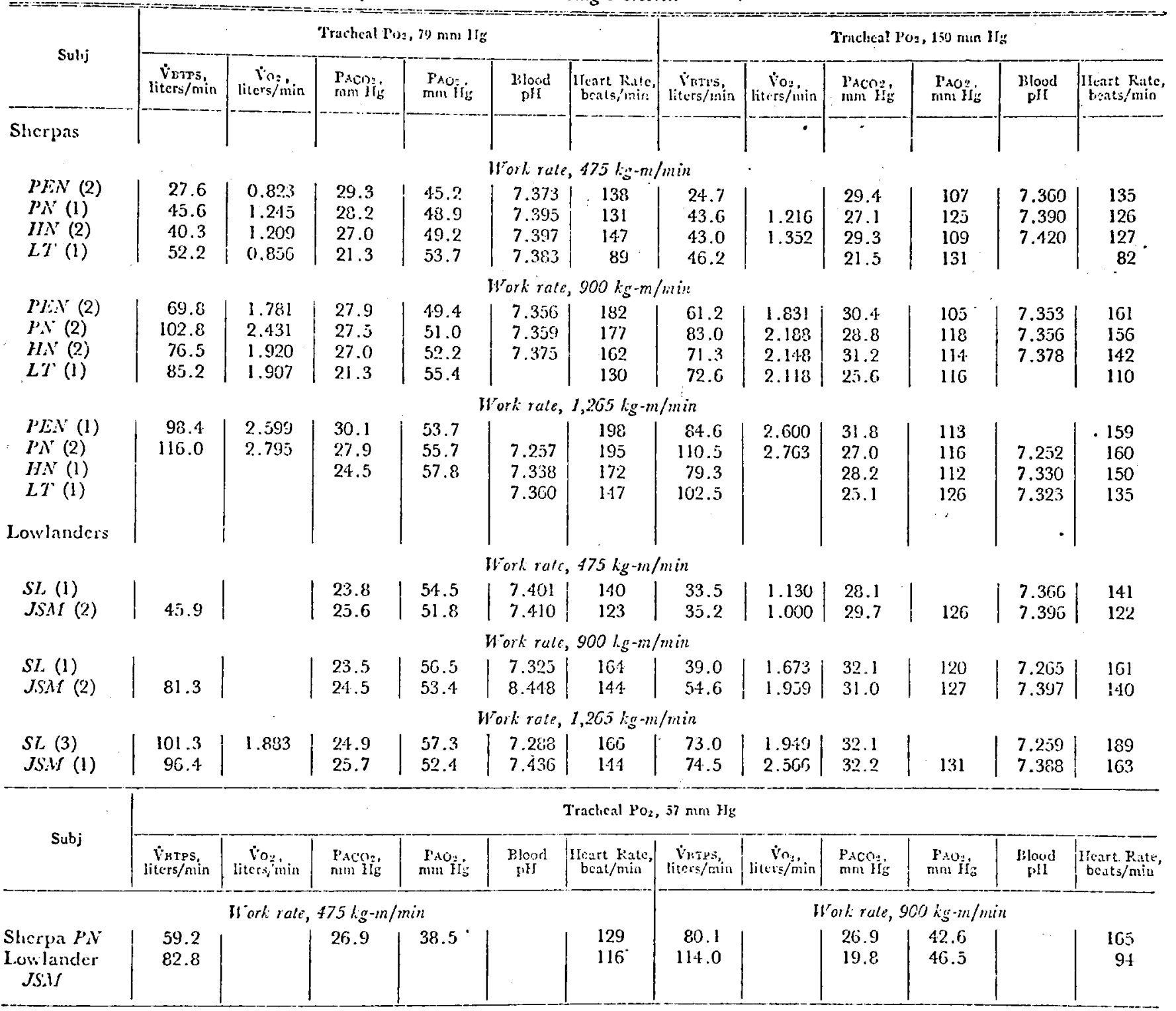

Number of observations on each subject arc given in parcitheses. 


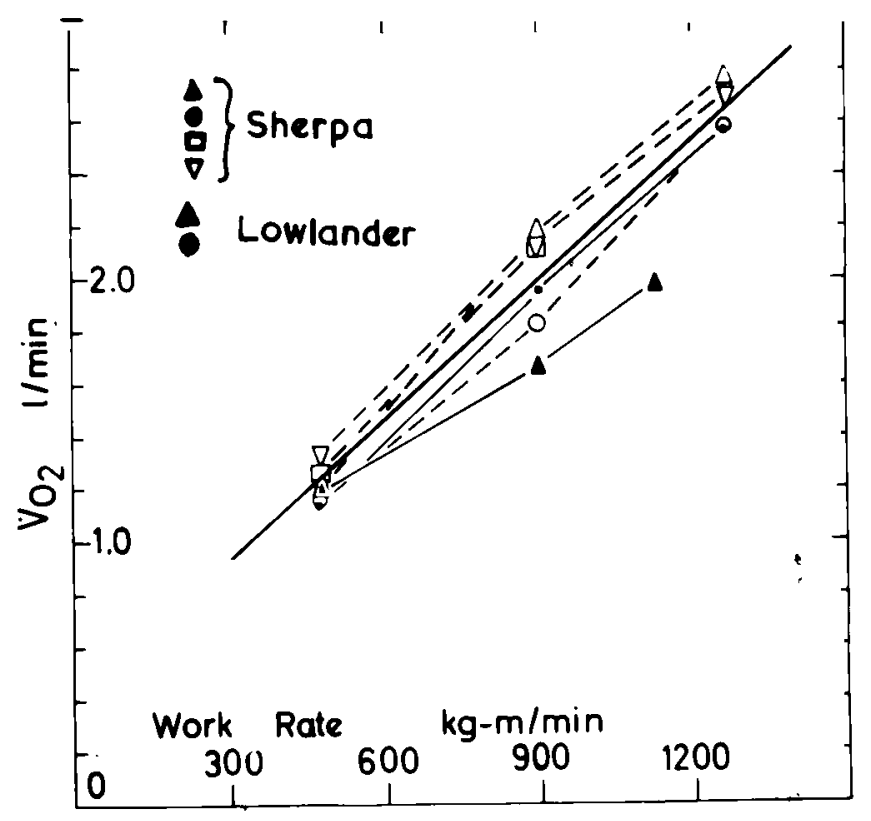

FIG. 5.1. Relation of $\mathrm{O}_{2}$ consumption to work rate. Symbols for individual subjects are joined by broken lines. The heavy line indicates the sea level relationship.

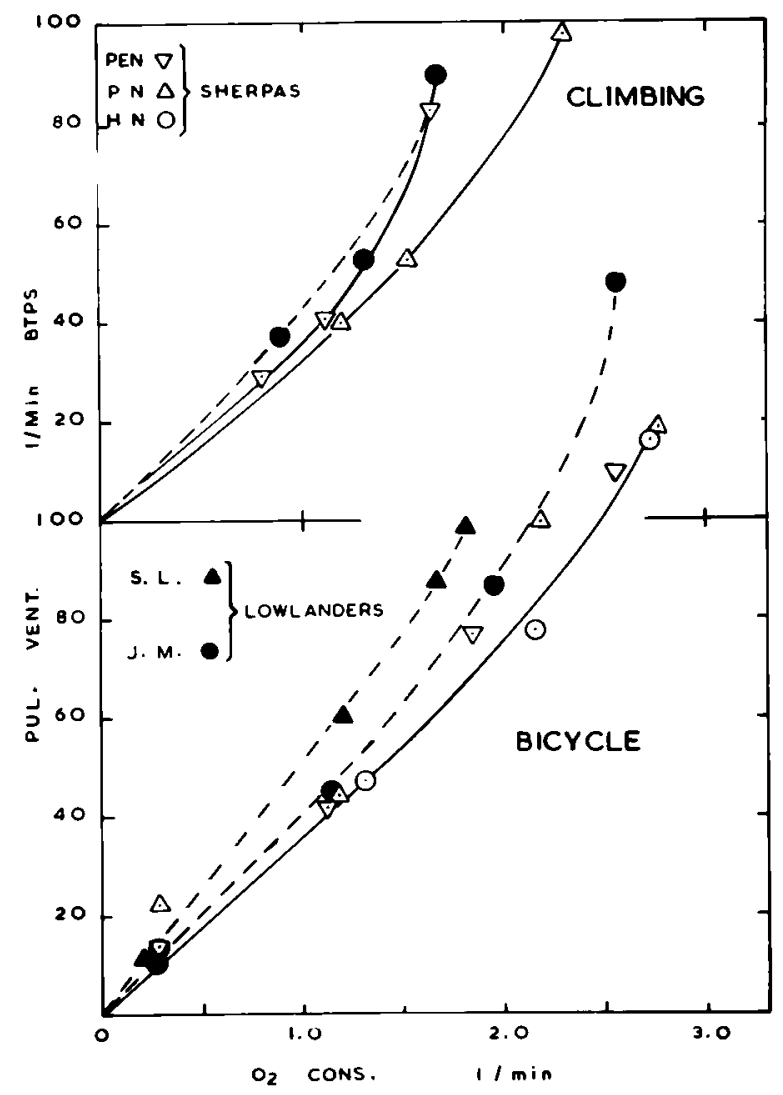

FIG. 5.2. Relation of ventilation to $\mathrm{O}_{2}$ consumption in lowlanders (closed symbols) and Sherpas (open symbols) durin two types of exercise. 


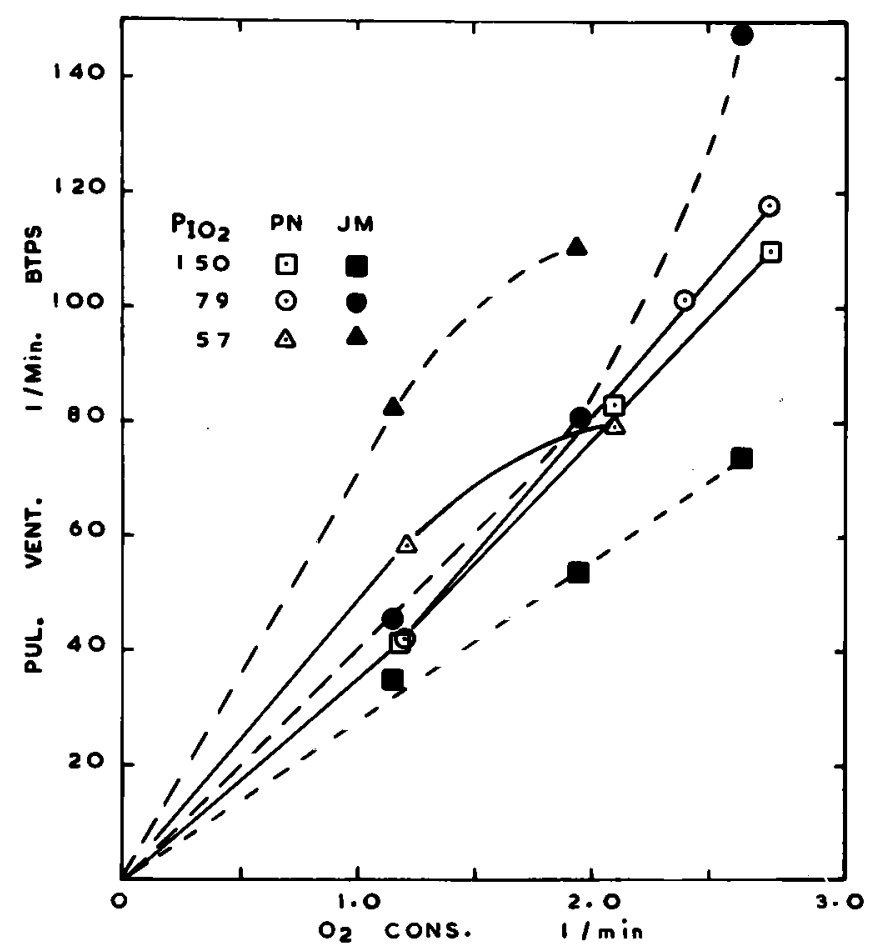

FIG. 5.3. The effect of changing the inspired $\mathrm{Po}_{2}$ on the relation of ventilation to $\mathrm{O}_{2}$ consumption in a lowlander, (closed symbols) and a Sherpa (open symbols).

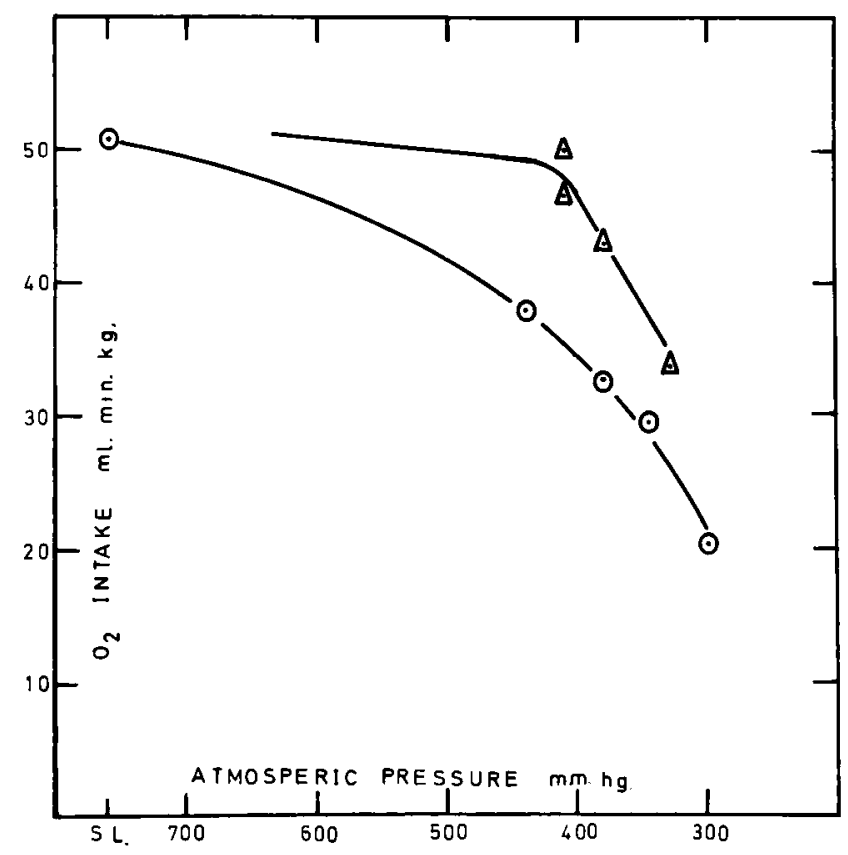

FIG 5.4. Relation of maximum $\mathrm{O}_{2}$ intake to atmospheric pressure; the lower line lowlanders, (from data in chapter 3 and fig 3.5); the upper line Sherpas. The end Sherpa point is that of a subject acclimatised to $4,380 \mathrm{~m}$ acutely exposed to $\mathrm{PIO}_{2} 57 \mathrm{mmig}$. 
at the higher work load. In Sherpas, however, oxygen often increased ventilation at rest and produced only little change at a low work rate. A fall was appreciable on ly beyond an oxygen uptake of $1 \mathrm{l} / \mathrm{min}$ where fal1 in arterial oxygen saturation is known to increase progressively on air (West, Lahiri, Gi11, Milledge, Pugh and Ward, 1962 and Banchero, Sine, Penaloza, Cruz, Gambo and Marticorena, 1966). The greatest reduction in ventilation was only 14 per cent, and this value did not change for oxygen uptake values in excess of $21 / \mathrm{min}$. Subjectively, the lowlanders felt great relief from breathing sea leve1 $\mathrm{P}_{I_{2}} \mathrm{O}_{2}$ but the Sherpa subjects did not seem to derive the same benefit. On acute exposure at $4,880 \mathrm{~m}$ to a tracheal $\mathrm{PO}_{2}$ of $57 \mathrm{~mm} \mathrm{Hg}$, ventilation in lowlander J.S.M. increased greatly while Sherpa P.N. showed only a small increase. Both subjects showed extreme exhaustion at $900 \mathrm{~kg}-\mathrm{m} / \mathrm{min}$, but the Sherpa subject was able to continue for $6 \mathrm{~min}$ while J.S.M. stopped after $3 \mathrm{~min}$. Fig. 5.3 shows the effect on ventilation of increasing and decreasing $\mathrm{P}_{1} \mathrm{O}_{2}$ in these two subjects.

The respiratory exchange ratio was higher in the Sherpas, and there was a smaller increase with exercise than in the lowlanders at altitude.

Submaximal work and oxygen debt

These results are given in Table 5.4. The Sherpa's $\mathrm{O}_{2}$ debt and blood lactate for a given work rate were somewhat smaller than those of the lowlanders. The rate of recovery to the basal state with respect to ventilation, $\mathrm{O}_{2}$ debt, and lactate did not appear appreciably different. Resting blood lactate in both groups was higher than the normal sea level value, which is in conformity with published reports (Asmussen, von Dobeln and Nielsen, 1948, and Klausen, 1966) on acclimatized lowlanders. 
Table 5.4. Oxygen uptake and blood lactate concentration at rest, during last half minute of $3-\mathrm{min}$ exercise period, and after exercise at $4,880 \mathrm{~m}$.

\begin{tabular}{|c|c|c|c|c|c|c|c|c|}
\hline \multirow{3}{*}{ Subject } & \multicolumn{4}{|c|}{ Oxygen uptake, 1iters/min } & \multicolumn{4}{|c|}{ B lood lactate, $\mathrm{mg} / 100 \mathrm{ml}$} \\
\hline & \multirow{2}{*}{ Rest } & \multirow{2}{*}{ Work } & \multicolumn{2}{|c|}{ After work } & \multirow{2}{*}{ Rest } & \multicolumn{3}{|c|}{ Min after work } \\
\hline & & & $\begin{array}{c}\text { First } \\
\min \end{array}$ & $\begin{array}{l}\text { Next } 10 \\
\text { min }\end{array}$ & & $2-3$ & $9-10$ & $15-16$ \\
\hline $\begin{array}{l}\text { Sherpas } \\
\text { P.E.N. } \\
\text { P.N. } \\
\text { H.N. } \\
\text { L.T. }\end{array}$ & $\begin{array}{l}0.267 \\
0.277 \\
0.296 \\
0.265\end{array}$ & $\begin{array}{l}2.599 \\
2.794 \\
1.486 \\
1.690\end{array}$ & $\begin{array}{l}0.782 \\
0.585 \\
0.638 \\
0.370\end{array}$ & $\begin{array}{l}0.325 \\
0.375 \\
0.223 \\
0.215\end{array}$ & $\begin{array}{l}16.1 \\
20.7 \\
17.8 \\
21.9\end{array}$ & $\begin{array}{l}73.2 \\
67.3 \\
48.5 \\
50.2\end{array}$ & $\begin{array}{l}49.5 \\
62.8 \\
49.4 \\
38.8\end{array}$ & $\begin{array}{l}45.4 \\
39.8 \\
33.3 \\
30.8\end{array}$ \\
\hline $\begin{array}{l}\text { Low lande } \\
\text { S.L. } \\
\text { J.S.M. }\end{array}$ & $\begin{array}{l}\text { s } \\
0.227 \\
0.290\end{array}$ & $\begin{array}{l}1.850 \\
2.363\end{array}$ & $\begin{array}{l}0.764 \\
0.533\end{array}$ & $\begin{array}{l}0.396 \\
0.368\end{array}$ & $\begin{array}{l}23.7 \\
24.5\end{array}$ & $\begin{array}{l}92.6 \\
73.8\end{array}$ & $\begin{array}{r}103.2 \\
61.2\end{array}$ & $\begin{array}{l}68.4 \\
46.8\end{array}$ \\
\hline
\end{tabular}

\section{Exercise and acid-base}

In Table 5.4 are also shown the results of $\mathrm{pH}$ and $\mathrm{P}_{A} \mathrm{CO}_{2}$ measurements. It wi 11 be seen that in Sherpas increasing exercise results in reductions in $\mathrm{pH}$ while $\mathrm{P}_{\mathrm{A}} \mathrm{CO}_{2}$ remained unchanged. One lowlander, J.S.M., has a rise in $\mathrm{pH}$ while the other, S.L. had a fall. Both had a reduction in $\mathrm{P}_{\mathrm{A}} \mathrm{CO}_{2}$.

\section{DISCUSSION}

Our findings confirmed the impression that at altitude Sherpas do not hyperventilate on exercise as much as lowlanders. This effect is not very marked at 1 ight and moderate work rates $\left(\mathrm{O}_{2}\right.$ intake less than $1.5 \mathrm{l} / \mathrm{min})$. However, at an oxygen intake of 2 liters the Sherpas ventilate 
at only about 80 per cent of the lowlander's value, while at an oxygen intake of $2.51 / \mathrm{min}$ (the lowlander's maximum work rate) the figure is only 70 per cent or less.

The greater efficiency of Sherpas is even more marked when maximum oxygen intake is considered. Fig. 5.4 shows the same graph of subjects as was used in Chapter III; we see the maximum oxygen intake (per $\mathrm{kg}$ weight) declining with altitude. The data from the second expedition is added together with the one Sherpa studied in 1961. It will be seen that at the altitude of our 1964 station $(4,880 \mathrm{~m})$ the two Sherpas who were able to achieve maximum work rate on the bicycle ergometer had maximum oxygen intake of 46.5 and $50.0 \mathrm{ml} / \mathrm{min} / \mathrm{kg}$, whi le the lowlanders had values of 37 (J.S.M.) and 30 (S.L.). The former value lies on the line of the graph from the previous expedition. Thus, at this altitude Sherpas have a maximum oxygen intake which is norma 1 for lowlanders at sea leve 1 (Asmussen, 1965). It should be noted however that Balke (1965) found lower values in Andean high altitude residents, $36.5 \mathrm{~m} 1 / \mathrm{min} / \mathrm{kg}$, the same as for lowlanders. Elsner, Bolstad and Forno (1964) found similar results.

The last Sherpa point in Fig. 5.4 is that of Sherpa P.N. acclimatized to $4,880 \mathrm{~m}$ and accutely exposed to a $\mathrm{P}_{\mathrm{I}} \mathrm{O}_{2}$ of $57 \mathrm{~mm} \mathrm{Hg}$. The 1 ine shown for Sherpas is, of course, very tentative because of the rather meager data.

This relative hypoventilation in people resident at high altitude has been reported from the Andes by Balke (1964) and by Hurtado, Velasquez, Ranafarje, Lozano, Chavez, Aste-Salazar, Raynaforje, Sanchez and Munoz (1956), and therefore it would seem to be common to man resident at high altitude. But Grover, Reeves, Grover and Leather (1967) found no difference in vent $i$ lation at exercise between residents and new-comers at Leadville, 
Colorado, altitude $3,100 \mathrm{~m}$. Their findings are hard to explain, especially when closer scrutiny of their data shows that in both groups the ventilatory equivalent was we 11 above that predicted from $\mathrm{Fig} .3 .4$ and their $\mathrm{P}_{\mathrm{A}} \mathrm{CO}_{2}$ lower than expected from the literature (Rahn and 0tis, 1949). It is possible that the degree of hypoxia at Leadville was insufficient to produce the changes resulting in hypoventilation or that racial or genetic factors present in Himilayan and Andean high altitude residents is absent from the Caucasian subjects as suggested by these authors. Clearly more studies are required in different races and at intermediate altitudes.

Hypoxic insensitivity

We consider that the principle cause of hypoventilation in the Sherpas is due to their relative insensitivity to hypoxia, as demonstrated in the previous chapter. In the experiments where the $\mathrm{P}_{1} \mathrm{O}_{2}$ was raised to sea level values or lowered, the effect on ventilation in Sherpas was quite different from that seen in lowlanders (Table 5.3 and Fig. 5.3). The change in ventilatory equivalent ( $\triangle V E$ ) on changing from ambient $\mathrm{P}_{1} \mathrm{O}_{2}$ $\left(79 \mathrm{~mm} \mathrm{Hg}\right.$ ) to sea leve $1 \mathrm{P}_{\mathrm{I}} \mathrm{O}_{2}$ is an average of 3 in Sherpas and about 12 in lowlanders (J.S.M.). In the one experiment in which the $\mathrm{P}_{\mathrm{I}} \mathrm{O}_{2}$ was lowered, the Sherpa did respond by an increase in ventilation, but less so than the lowlander, $\triangle V E=13$ in the Sherpa and 17 in the lowlander. The changes in $\mathrm{P}_{\mathrm{A}} \mathrm{CO}_{2}$ reflect and confirm this change in ventilation.

\section{Acid-base differences in exercise}

The differences in the reaction of the blood to the response to exercise is shown in Table 5.5, where the arterial pH of a representative lowlander and Sherpa are compared at various work rates. 
Table 5.5. $\mathrm{pH}$ and $\mathrm{P}_{50}$ in a representative lowlander and Sherpa during exercise at $4,880 \mathrm{~m}$.

\begin{tabular}{|c|c|c|c|c|}
\hline \multirow{2}{*}{$\begin{array}{l}\text { Work Rate } \\
\mathrm{kg}-\mathrm{m} / \mathrm{min}\end{array}$} & \multicolumn{2}{|c|}{$\begin{array}{c}\text { Low lander } \\
\text { J.S.M. }\end{array}$} & \multicolumn{2}{|c|}{$\begin{array}{l}\text { Sherpa } \\
P . E . N .\end{array}$} \\
\hline & $\mathrm{pH}$ & $\begin{array}{c}P_{50} \\
\mathrm{~mm} \mathrm{Hg}\end{array}$ & $\mathrm{pH}$ & $\begin{array}{c}\mathrm{P}_{50} \\
\mathrm{~mm} \mathrm{Hg}\end{array}$ \\
\hline Rest & 7.424 & 26.8 & 7.403 & 27.6 \\
\hline 475 & 7.410 & 27.2 & 7.373 & 28.3 \\
\hline 900 & 7.448 & 26.2 & 7.356 & 28.8 \\
\hline 1265 & 7.436 & 26.5 & 7.318 & 29.7 \\
\hline
\end{tabular}

It will be seen that whereas the Sherpa's reaction becomes more acid with increasing exercise, the lowlander's blood becomes slightly more alkaline. The difference is presumably due to the respiratory alkalosis of hyperventilation in the lowlander countering the metabolic acidosis of anaerobic metabolism, while in the Sherpas $\mathrm{P}_{A} \mathrm{CO}_{2}$ is unchanged so that metabolic acidosis is unopposed.

What is the effect of this difference in $\mathrm{pH}$ on the oxygen transport systems of the two groups? In Table 5.5 is shown the calculated position of the oxygen dissociation curve expressed as the $\mathrm{PO}_{2}$ when 50 per cent of the hemoglobin is saturated $\left(P_{50}\right)$, assuming there is no difference in the type of hemoglobin between Sherpas and lowlanders. At rest both groups are a little below the normal value of $28 \mathrm{~mm} \mathrm{Hg}$, the lowlander being lower than the Sherpa, i.e. the curve is shifted slightly to the left of norma 1. The $P_{50}$ for the lowlander remains unchanged as work rate is increased, but 


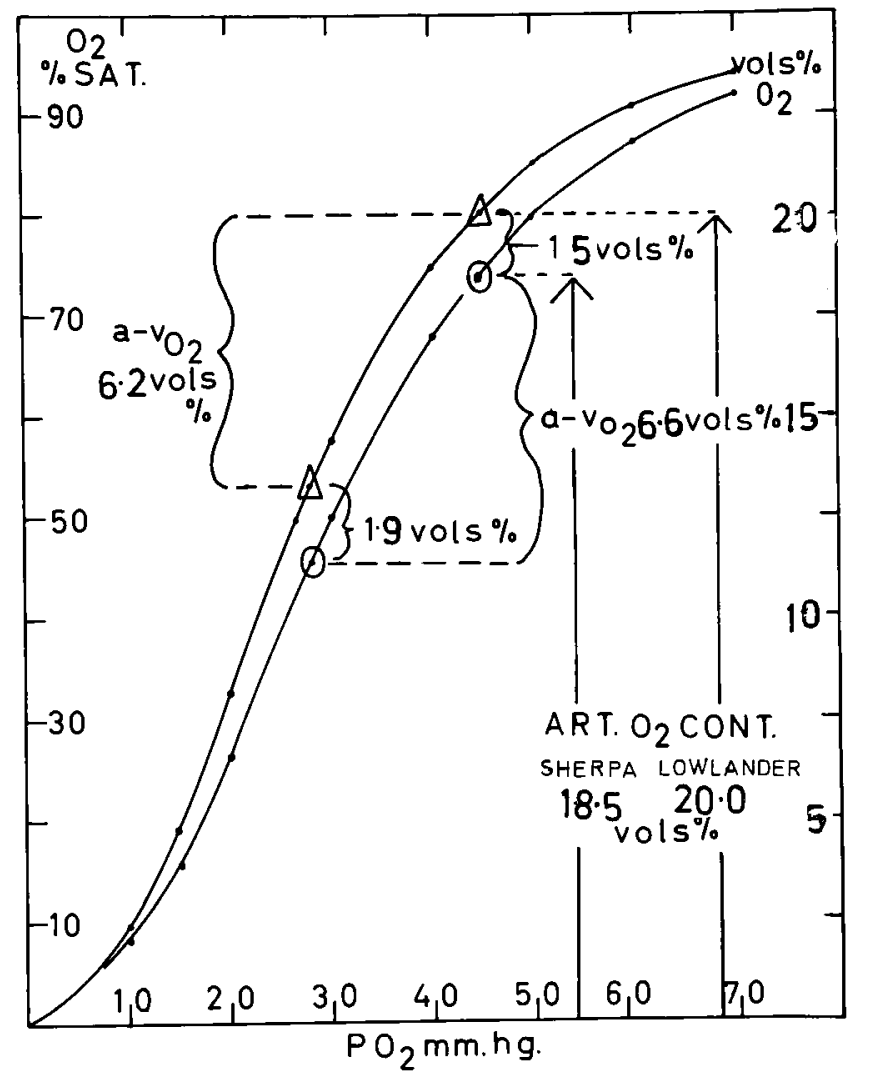

TI. 5.5. Oxygen dissociation curves calculated ior blood of a lowlander (JSM) P50 $=26.5$, and a Sherpa (PEN) $\mathrm{P} 50=29.7$ at maximum work rate at $4,880 \mathrm{~m}$ altitude. Venous points ignore Bohr ef ect. 
for the Sherpa it increases progressively unti1 it reaches $29.7 \mathrm{~mm} \mathrm{Hg}$, i.e. a shift to the right of the dissociation curve (Fig. 5.5). These calculations and the curves in Fig. 5.5 were made from the Severinghaus blood gas calculator (Severinghaus, 1966). So at rest the two curves are very close, but at maximum work rate they are separated by $3.2 \mathrm{~mm} \mathrm{Hg}$ at $P_{50^{*}}$ This means that assuming the same $\mathrm{PaO}_{2}$ of $45 \mathrm{~mm} \mathrm{Hg}$ the lowlander's blood is saturated by 6.0 per cent more than the Sherpa's blood or 1.5 vols per cent with an $\mathrm{O}_{2}$ capacity of 25 vols per cent, the normal value for both Sherpas and lowlanders at this altitude (Fig. 5.5).

The effect on the tissue oxygen supply depends upon the position on the dissociation curve of the venous point, which in turn depends upon the blood flow and metabolism, or the oxygen extraction of the particular tissue. In the case of low extraction organs such as kidney and even the brain, the Sherpa may not be at a disadvantage. For these organs the venous point is on the steep part of the dissociation curve at $\mathrm{PO}_{2}$ 25-35 $\mathrm{mm} \mathrm{Hg}$ where for a given $\mathrm{P}_{\mathrm{v}} \mathrm{O}_{2}$ a much greater amount of oxygen will be unloaded; e.g. at $\mathrm{PO}_{2} 28 \mathrm{~mm} \mathrm{Hg}$ the two curves are separated by 7.5 per cent saturation or 1.9 vols per cent, giving 0.4 vols per cent more $\mathrm{O}_{2}$ for the same a-v $\mathrm{PO}_{2}$ difference (ignoring the Bohr effect). But in the case of high extraction organs such as heart and especially working muscles which can apparently extract $\mathrm{O}_{2}$ to almost zero $\mathrm{PO}_{2}$, lowlander's blood will be able to deliver more $\mathrm{O}_{2}$ than Sherpas. This situation holds for any $\mathrm{PVO}_{2}$ less than about $20 \mathrm{~mm} \mathrm{Hg}$.

The observed hypoventilation in Sherpas due to hypoxic insensitivity and its effect on arterial $\mathrm{pH}$ and $\mathrm{O}_{2}$ dissociation curve would seem to be disadvantageous in terms of oxygen supply to the tissues, especially to 
the working muscles. We must therefore look to other mechanisms for the explanation of the Sherpa's greater efficiency at high altitude. Degraph, Grover, Hammond, Miller and Johnson (1965) have shown highlanders to have twice the membrane component of diffusing capacity found in lowlanders. This is probably of great importance on heavy exercise since we found lowlanders at altitude develop increasingly wide $\mathrm{A}_{-} \mathrm{a} \mathrm{O}_{2}$ gradients due to diffusion limitations and their arterial $\mathrm{O}_{2}$ saturation falls to the low 40 per cent levels (West, et al., 1962). Another factor in tissue oxygen supply is cardiac output. We found that the heart rate and cardiac output in lowlanders was limited to a lower maximum than at sea level (Pugh et a 1., 1964; Pugh, 1964) whereas we found no such limitation to heart rate in Sherpas (Lahiri, Milledge, Chattopadhyay, Battacharya and Sinha, 1967). There may also be further differences such as a richer capi 11 ary network which gives highlanders an advantage especially in heavy work, about which we have little data.

\section{CONCLUSION}

These exercise studies show a definite relative hypoventilation in Sherpas compared with acclimatized lowlanders at the same altitude. The experiments in which $\mathrm{P}_{\mathrm{I}_{2}}$ was raised or lowered confirm the results of the resting studies discussed in the previous chapter that Sherpas have a markedly reduced respiratory hypoxic sensitivity.

This hypoventilation in Sherpas results in a lower arterial pH at rest which becomes lower still on exercise, whereas in lowlanders the arterial $\mathrm{pH}$ tends to rise slightly. Thus the $\mathrm{H}^{+}$stimulus to breathing is actually considerably greater in the Sherpa at exercise. This pH difference therefore to some extent masks the difference in respiratory response 
These differences in themselves would tend to reduce oxygen supply to the tissues because: 1) the lower ventilation results in reduced $\mathrm{P}_{A} \mathrm{O}_{2}$ and $\mathrm{PaO}_{2}$ and 2) the lower arterial pH shifts the oxygen dissociation curve to the right thus reducing still further the arterial $\mathrm{O}_{2}$ saturation and content. These findings do not explain the Sherpa's efficiency compared with lowlanders at altitude. 


\section{REFERENCES}

Chapter V

Asmussen, E., W. von Dobein and M. Nielsen (1948). Blood lactate and oxygen debt after exhaustion work at different oxygen tensions. Acta Physio1. Scand 15, 57-62.

Asmussen, E. (1965). Muscular exercise; in Handbook of Physiology, Section 3: Respiration. Washington, D. C.: American Physiological Society, Vo1. 2, pp. 939-978.

Balke, B. (1964). Work capacity and its limiting factors at high altitude; in The Physiological Effects of High Altitude, edited by W. H. Wiehe. New York: Macmillan, pp. 233-247.

Banchero, N., F. Sine, D. Penaloza, J. Cruz, R. Gambo and E. Marticorena (1966). Pulmonary pressure, cardiac output, and arterial oxygen saturation during exercise at high altitude and at sea level. Circulation $33,249-262$.

Barker, S. B. and W. H. Summers on (1941). Calorimetric determination of lactic acid in biological material. J. Biol. Chem. 138, 535.

Cunningham, D. J. C., D. G. Shaw, S. Lahiri and B. B. Lloyd (1961). The effect of maintained ammonium chloride acidosis on the relation between pulmonary ventilation and alveolar oxygen and carbon dioxide in man. Quart. J. Exp. Physiol. 46, 323-334.

Degraph, A. C., Jr., R. F. Grover, J. W. Hammond, Jr., J. M. Miller, and R. L. Johnson, Jr. (1965). Pulmonary diffusing capacity in persons native to high altitude (abstract). Cir. Res. Proc. 13, 346.

Elsner, R. W., A. Bolstad and C. Forno (1964). Maximum oxygen consumption of Peruvian Indians native to high altitude; in The Physiological Effects of High Altitude, edited by W. H. Weihe. New York, Macmillan, pp. 217-221.

Grover, R. F., J. T. Reeves, E. B. Grover and J. E. Leather (1967). Muscular exercise in young men native to $3,100 \mathrm{~m}$ in altitude. J. App1. Physiol. $22,555-556$.

Hurtado, A., T. Velasquez, C. Ranafarje, R. Lozano, R. Chavez, H. AsteSalazar, B. Raynaforje, C. Sanchez and J. Munoz (1956). Mechanisms of natural acclimatization; studies on the native resident of Morococha, Peru, at an altitude of 14,900 ft. Air Force School of Aviation Medicine, Randolph Fie1d, Report No. 56-1, pp. 1-62. 
Klausen, K. (1966). Cardiac output in man in rest and work during and after acclimatization to 3,800 m. J. App 1. Physiol. 21, 609-616.

Lahiri, S., J. S. Milledge, H. P. Chattopadhyay, A.K. Bhattacharya and A. K. Sinha (1967). Respiration and heart rate of Sherpa highlanders during exercise. J. App1. Physio1. 23, 545-554.

Pugh, L. G. C. E., M. B. Gi11, S. Lahiri, J. S. Milledge, M. P. Ward, J. B. West (1964). Muscular exercise at great altitude. J. App1. Physio1. 19, $431-441$.

Pugh, L. G. C. E. (1964). Cardiac output in muscular exercise at $5,800 \mathrm{~m}$ $(19,000 \mathrm{ft})$. J.App1. Physio1. 19, 441-447.

Rahn, H. and A. B. Ot is (1949). Man's respirat ory response during and after acclimatization to high altitude. Am. J. Physiol. 157, 445-462.

Severinghaus, J. W., M. Stupfe1, and A. F. Bradley (1956). Accuracy of blood $\mathrm{pH}$ and $\mathrm{PCO}_{2}$ determinations. J. App1. Physio1. 9, 189-196.

Severinghaus, J.W. (1966). Blood gas calculator. J. App1. Physiol. $21,1103-1116$.

Siggaard-Andersen, 0., K. Enge 1, K. Jørgensen, and P. Astrup (1960). A micromethod for the determination of $\mathrm{pH}$, carbon dioxide tension, base excess and standard bicarbonate in capillary blood. Scand. J. Clin. Lab. Invest. 12, 171-176.

West, J. B., Lahiri, M. B. Gi11, J. S. Milledge, and L. G. C. E. Pugh and M. P. Ward (1962). Arterial oxygen saturation during exercise at high altitude. J. App1. Physio1. 17:617-621. 
C H A P T E R V I

BLOOD AND CSF ACID-BASE BALANCE IN MAN AT HIGH ALTITUDE

In considering the effect of a 1titude on the control of breathing in the previous chapters, we have shown in some detail the changes in ventilation resulting from $\mathrm{CO}_{2}$ inhalation and hypoxia and from exercise at various altitudes. In this way we have measured the effect of altitude on the control mechanism, and the differences in the setting of this mechanism as a whole between highlanders and lowlanders.

In this chapter we consider the factors underlying this setting of the control mechanism. The most important factor is thought to be the acidbase state of the environment of the central respiratory center or of receptor sites close to it. Therefore, we collected data on blood and CSF on the second expedition (1964) and in Peru (1968). In this chapter this data is considered.

In Chapter II we showed that there was a correlation between shift to the left of the $\mathrm{CO}_{2}$ response curve (reduction in $\mathrm{B}$ ) and the reduction in plasma $\mathrm{HCO}_{3}^{-}$(Fig. 2.6). However, there was a discrepancy between our results and those from experiments on metabolic acidosis (Cunningham, Shaw, Lahiri and Lloyd, 1961). This was presumably due to the difference in CSF response to metabolic and respiratory acidosis. It was therefore obvious that to gain insight into the mechanism of the change in respiratory control we needed to know not only the acid-base status of the blood, but a 1 so that of the CSF. 
On the second expedition (1964) we sampled arterial and capillary blood, and CSF from lowlanders and Sherpas at 4,880 m (16,000 ft).

In 1968 as part of a study on cerebral metabolism we measured arterial and CSF pH, $\mathrm{CO}_{2}$ and arterial and jugular venous $\mathrm{PO}_{2}$ and $\mathrm{O}_{2}$ content on Andean high altitude natives at 4,330 $\mathrm{m}(14,300 \mathrm{ft})$ in Peru.

\section{SUBJECTS}

The physical characteristics of the subjects in the 1964 expedition have been given in Table 4.1. Two of the lowlanders had only been at the physiological camp for 24 hours when measurements were taken; their CSF values were similar to the other lowlanders, but their blood values were different and they could not be considered fully acclimatized. Therefore, for the purposes of comparison with acclimatized Sherpas, their results have been excluded. In 1968 we studied 16 subjects, a 11 born and resident at $4,300 \mathrm{~m}$.

\section{METHODS}

Al1 sampling of CSF, blood and alveolar gas was done at least 2 hours after a light breakfast. Lumbar CSF which gives a good estimation of cisternal CSF in steady state (Bradley and Semple, 1962; Fisher and Christianson, 1963) was used in all of our CSF estimations. Prior to lumbar puncture the subject lay comfortably on his right side on a bed in a separate tent. After about $10 \mathrm{~min}$ the subject delivered Haldane-andPriestly end-expiratory samples which were collected in Barcroft tubes by displacement of mercury and stored under positive pressure unti 1 analyzed. Within $10 \mathrm{~min}$ of alveolar sampling lumbar CSF was drawn anaerobically. For this the space between second and third lumbar was anesthetized with 1 cc of 1 per cent lignocaine. A short 20-gauge needle was placed deeply in the interspinous ligaments through which a 26-gauge spinal needle was 
driven slowly until spinal fluid started flowing after the removal of the stylet. A $10 \mathrm{ml}$ syringe whose plunger was sealed with mineral oil was connected to the needle and about a $\mathrm{ml}$ of CSF was collected for filling the dead space. Excess fluid was rejected, and the syringe reconnected to the needle and about $8 \mathrm{ml}$ CSF collected completely anaerobically. Its $\mathrm{pH}$ was measured immediately with a Radiometer $\mathrm{pH}$ meter $\mathrm{M}_{4}$ and an Astrup capillary micro-electrode. Temperature at the electrodes was around $37^{\circ} \mathrm{C}$ and the fina 1 values were corrected to $37^{\circ} \mathrm{C}$ using the factor of $-0.004 \mathrm{pH}$ unit per degree as found by Mitche11 (in Severinghaus et al., 1963) and verified by us. This measurement showed a drift with the first reading, and eventually $3-4$ samples were taken into the microelectrode for a stable $\mathrm{pH}$ value. Phosphate buffers of $\mathrm{pH} 6.840$ and 7.384 were used as the standards and for determining the sensitivity of the electrodes.

The remaining sample was kept anaerobic in an ice bath for other measurements. Total $\mathrm{CO}_{2}$ in $1 \mathrm{ml}$ samples was measured in a modified Haldane blood-gas analysis apparatus as described by Cunningham et a1. (1961) for blood. For lactate measurement later in Calcutta $0.1 \mathrm{~m} 1 \mathrm{CSF}$ was diluted to $10 \mathrm{ml}$ in a final concentration of 5 per cent trichloroacetic acid. Lactate was determined by a modification of the method of Barker and Summerson (1941). A 4-5 m1 sample was used for the construction of a three-point $\mathrm{CO}_{2}$ dissociation curve. The remaining $\mathrm{CSF}$, if any, was sealed in a $10 \mathrm{ml}$ plastic bottle and frozen for later use for $\mathrm{Na}^{+}$and $\mathrm{K}^{+}$estimation by flame photometry in Calcutta. For $\mathrm{CO}_{2}$ dissociation the usual tonometric method was employed using $1.5 \mathrm{~m} 1$ samples. At the end of 12 minutes equilibration at $37^{\circ} \mathrm{C}$ with $\mathrm{CO}_{2}$ the total pressure above atmospheric was noted. CSF was then sampled directly from the tonometer anaerobically into the capillary microelectrode and $\mathrm{pH}$ was measured as before. The 
tonometer gas was collected at the same temperature for $\mathrm{CO}_{2}$ analysis. On several occasions the total $\mathrm{CO}_{2}$ of the tonometer CSF sample was measured. A11 respiratory gas analysis was done with the Lloyd-Haldane gas analyzer. Most of the blood $\mathrm{pH}$ measurements were made on capillary blood from the finger tip of the warmed hand. In a few instances blood was obtained by arterial puncture and its $\mathrm{pH}$ and whole blood total $\mathrm{CO}_{2}$ were measured as for CSF. Temperature correction for blood $\mathrm{pH}$ at $37^{\circ} \mathrm{C}$ was made according to Severinghaus, Stumpfel and Bradley (1956).

A11 CSF and blood measurements were made on a Sherpa and a lowlander in pairs. This was planned deliberately to minimize the relative error between the two groups in measurements of $\mathrm{pH}$ under conditions which could not be controlled rigorous ly.

The methods used in Peru in 1968 were similar except that a 11 blood samples were by arterial puncture and the equipment used was a Beckman 160 physiological gas analyzer, a Radiometer $\mathrm{PO}_{2}$ electrode and a Bradley $\mathrm{pH}$ electrode. A working phosphate buffer, pH 6.950 was used. This was checked on alternate days with freshly opened Radiometer precision phosphate buffer, $\mathrm{pH} 6.841$ and 7.383 . The working buffer solution did not change over the two weeks at Cerro-de-Pasco. The blood and CSF were analyzed for total $\mathrm{CO}_{2}$, and the blood for total $\mathrm{O}_{2}$ by the Van Slyke method. The $\mathrm{PCO}_{2}$ results reported are those calculated from the total $\mathrm{CO}_{2}$ and $\mathrm{pH}$. Since a direct $\mathrm{PCO}_{2}$ measurement in CSF is likely to be inaccurate, it was not attempted. In calculating the $\mathrm{PCO}_{2}$ of blood the nomogram of Van Slyke was used to obtain plasma $\left[\mathrm{HCO}_{3}^{-}\right]$and from this and the $\mathrm{pH}$, the $\mathrm{PcO}_{2}$ was calculated using the Henderson-Hasselbalch equation and a $\mathrm{pK}^{\prime}$ of 6.130 in CSF and 6.100 for blood was used. 
RESULTS

The results are given in Tables 6.1 to 6.4 .

Lowlanders and Sherpas, 1964

The numbers of subjects in 1964 are smal1, but the results are consistent (Tables 6.1 and 6.2). Lowlanders even after a stay of two to six weeks do not completely correct their respiratory alkalosis and their arterial blood $\mathrm{pH}$ remains slightly elevated (mean, 7.439). The CSF pH of lowlanders is also elevated (mean, 7.383 ; norma 1 about 7.32 ). It is perhaps worth noting that the highest blood and CSF pH values were on subject A.B. (30 days at $4,880 \mathrm{~m}$ ) who was unable to acclimatize and was eventually forced to go down to base camp. The Sherpas on the other hand had normal blood pH (mean, 7.399) and CSF pH (mean, 7.328) at 4,880 m.

In Sherpas the arterial $\mathrm{PCO}_{2}$ was $2 \mathrm{~mm} \mathrm{Hg}$ higher than that of the lowlanders, reflecting their slightly lower ventilation; the CSF $\mathrm{PCO}_{2}$ is a 1 so $3 \mathrm{~mm} \mathrm{Hg} \mathrm{higher.} \mathrm{Both} \mathrm{groups} \mathrm{have} \mathrm{a} \mathrm{normal} \mathrm{arterial-CSF} \mathrm{PcO}_{2}$ gradient of about $9 \mathrm{~mm} \mathrm{Hg}$.

The plasma $\left[\mathrm{HCO}_{3}^{-}\right]$is similar in the two groups (Sherpas, mean 17.1 $\mathrm{mEq} / 1$, lowlanders, mean $17.4 \mathrm{mEq} / 1$ ), showing the we 11 known reduction with acclimatization. In CSF there is a difference of $0.7 \mathrm{mEq} / 1$ : Sherpas, mean $19.1 \mathrm{mEq} / 1$; lowlanders, mean $19.8 \mathrm{mEq} / 1$. That is, Sherpas have a slight cerebral acidosis as compared with lowlanders.

\section{Andean subjects (Tables 6.3 and 6.4 )}

In Andean natives at $4,330 \mathrm{~m}(14,300 \mathrm{ft})$ we find normal arterial pH values (mean $7.412 \pm 0.013$ ). Compared with Sherpas and lowlanders at $4,880 \mathrm{~m}$ we find less reduction in plasma $\left[\mathrm{HCO}_{3}^{-}\right]($mean $21.2 \pm 1.0 \mathrm{mEq} / 1)$ 
TABLE 6.1. Arterial blood data in Sherpas and lowlanders at

$$
4,880 \mathrm{~m} \text {. }
$$

$\begin{array}{llllll}\text { Subject } & \mathrm{pH} & \mathrm{HCO}_{3}^{-} & \mathrm{PcO}_{2} & \text { Lactate } & \mathrm{Hb} \\ & \mathrm{mEq} / 1 & \mathrm{~mm} \mathrm{Hg} & \mathrm{mM} / 1 & \mathrm{~g} \%\end{array}$

Sherpas

$\begin{array}{llllll}\text { P.E.N. } & 7.403 & 17.3 & 28.2 & 1.80 & 20.9\end{array}$

$\begin{array}{llllll}\text { P.N. } & 7.387 & 17.3 & 29.3 & 2.31 & 16.9\end{array}$

$\begin{array}{llllll}\text { L.T. } & 7.408 & 16.9 & 27.2 & 2.30 & 17.8\end{array}$

\begin{tabular}{llllll} 
H.N. & 7.400 & 17.7 & 28.9 & 1.98 & 20.4 \\
\hline
\end{tabular}

$\begin{array}{llllll}\text { Mean } & 7.399 & 17.1 & 28.4 & 2.09 & 19.0\end{array}$

Low 1 anders

\begin{tabular}{llllll} 
J.S.M. & 7.424 & 17.1 & 26.6 & 2.98 & 19.7 \\
A.B. & 7.465 & 18.6 & 26.1 & 2.78 & 18.1 \\
S.L. & 7.429 & 16.5 & 25.6 & 2.76 & 20.4 \\
\cline { 2 - 5 } Mean & 7.439 & 17.4 & 26.1 & 2.84 & 19.4
\end{tabular}


TABLE 6.2. CSF data on Sherpas and lowlanders at 4,880 m.

\begin{tabular}{|c|c|}
\hline Subject & $\mathrm{pH}$ \\
\hline
\end{tabular}

Sherpas

\begin{tabular}{lllll} 
P.E.N. & 7.330 & 19.0 & 37.5 & 3.14 \\
P.N. & 7.311 & 19.0 & 39.1 & 2.91 \\
L.T. & 7.344 & 19.2 & 36.6 & 2.92 \\
\cline { 2 - 5 } Mean & 7.328 & 19.1 & 37.7 & 2.98
\end{tabular}

Lowlanders

\begin{tabular}{lccccc} 
J.S.M. & 1. & 7.370 & 19.6 & 35.2 & 3.18 \\
& 2. & 7.362 & 19.8 & 36.2 & -- \\
A.B. & & 7.417 & 20.1 & 32.4 & 3.10 \\
\cline { 3 - 6 } Mean & & 7.383 & 19.8 & 34.6 & 3.14
\end{tabular}


TABLE 6.3. Blood data of Andean high altitude natives at $4,300 \mathrm{~m}$.

$\begin{array}{lllll}\text { Subject } & \mathrm{pH} & \begin{array}{l}\mathrm{HCO}_{3} \\ \mathrm{mEq} / 1\end{array} & \begin{array}{l}\mathrm{PCO}_{2} \\ \mathrm{~mm} \mathrm{Hg}\end{array} & \begin{array}{c}\text { Haematocrit } \\ \%\end{array} \\ \text { D.N.F. } & 7.397 & 20.2 & 33.5 & 61.5 \\ \text { L.A. } & 7.405 & 21.9 & 35.6 & 64.0 \\ \text { J.G. } & 7.403 & 20.6 & 33.6 & 51.0 \\ \text { F.S. } & 7.398 & 23.2 & 38.3 & 67.0 \\ \text { E.R. } & 7.413 & 19.9 & 31.8 & 50.5 \\ \text { T.P. } & 7.422 & 21.6 & 33.6 & 60.5 \\ \text { P.V. } & 7.432 & 21.3 & 32.4 & 58.0 \\ \text { M.S. } & \mathbf{7 . 4 2 1} & 21.0 & \underline{33.5} & 50.5 \\ \text { Mean } & 7.412 \pm 0.013 & 21.2 \pm 1.0 & 34.0 \pm 2.0 & 57.9 \pm 6.5\end{array}$


TABLE 6.4. CSF data of Andean high altitude natives at $4,300 \mathrm{~m}$.

$\begin{array}{llll}\text { Subject } & \mathrm{pH} & \begin{array}{l}\mathrm{HCO} \\ \mathrm{mEq} / 1\end{array} & \begin{array}{l}\mathrm{PCO}_{2} \\ \mathrm{~mm} \mathrm{Hg}\end{array} \\ \text { D.N.F. } & 7.296 & 20.7 & 44.6 \\ \text { L.A. } & 7.311 & 21.7 & 45.4 \\ \text { J.G. } & 7.285 & 20.2 & 44.7 \\ \text { F.S. } & 7.276 & 23.0 & 52.0 \\ \text { E.R. } & 7.299 & 20.8 & 44.5 \\ \text { T.P. } & 7.268 & 21.5 & 49.5 \\ \text { P.V. } & 7.314 & 22.6 & 46.9 \\ \text { M.S. } & 7.281 & 22.0 & 49.2 \\ \text { Mean } & 7.291 \pm .016 & 21.6 \pm 1.0 & 47.1 \pm 2.8\end{array}$


and $\mathrm{PaCO}_{2}$ (mean $34.0 \pm 2.0 \mathrm{~mm} \mathrm{Hg}$ ). This is explained, at least in part, by the altitude difference.

The CSF results show a pH definitely lower than normal (mean pH 7.291 \pm 0.016 ). The $\left[\mathrm{HCO}_{3}^{-}\right]$is similar to arterial values (mean $21.6 \pm 1.0$ $\mathrm{mEq} / 1$ ). Mean $\mathrm{PCO}_{2}$ was $47.1 \pm 2.8$ which gives an arterial CSF gradient of $13.1 \mathrm{~mm} \mathrm{Hg}$.

Lactate in lowlanders and Sherpas, 1964

The blood lactates were significantly different between Sherpas (mean $2.09 \mathrm{mEq} / 1$ ) and lowlanders (mean $2.84 \mathrm{mEq} / 1$ ). CSF lactate values showed no significant difference (lowlanders, mean $3.14 \mathrm{mEq} / 1$, Sherpas, mean $2.89 \mathrm{mEq} / 1$ ). This means that there was a greater blood-CSF gradient in Sherpas $(0.89 \mathrm{mEq} / 1)$ than lowlanders $(0.30 \mathrm{mEq} / 1)$.

\section{DISCUSSION}

Respiratory acclimatization

The changes which bring about the alteration in control of breathing known as respiratory acclimatization must come to a focus at the central chemoreceptors which are believed to lie near the ventro-lateral surface of the medulla (Mitche11, Loeschke, Massion and Severinghaus, 1963). Functionally, the receptor cells seem to respond to hydrogen ion concentration somewhere on the gradient between CSF and blood, i.e. brain extracellular fluid (Mitche11 et a 1., 1963; Pappenheimer, Fencl, Heisey and He1d, 1965). The $\left[\mathrm{HCO}_{3}^{-}\right]$in this fluid provides the "setting" of the chemostat in terms of $\mathrm{PCO}_{2}$ according to the Henderson-Hasselbalch equation.

At sea level the CSF $\mathrm{pH}$ is approximately 7.32 and $\left[\mathrm{HCO}_{3}^{-}\right] 24.4 \mathrm{mEq} / 1$ and the $\mathrm{PCO}_{2} 49 \mathrm{~mm} \mathrm{Hg}$. If the $\mathrm{HCO}_{3}^{-}$is reduced to $19.1 \mathrm{mEq} / 1$ (as in our 
Sherpa subjects at altitude) the same $\left[\mathrm{H}^{+}\right]$is obtained only if the CSF $\mathrm{PCO}_{2}$ is reduced to $38 \mathrm{~mm} \mathrm{Hg}$ by hyperventilation. At any higher $\mathrm{PcO}_{2}$, the $\mathrm{H}^{+}$will be greater, thus providing an increased stimulus to breathing and an increased ventilation. This happens when an acclimatized subject inhales a $\mathrm{CO}_{2}$ gas mixture and the $\mathrm{CO}_{2}$ response curve from such an experiment originates from a lower $\mathrm{PcO}_{2}$ i.e. is shifted to the left. This is the clearest way of demonstrating respiratory acclimatization. Thus a reduction of $\mathrm{CSF}\left[\mathrm{HCO}_{3}^{-}\right]$(or more accurately brain extracellular $\left[\mathrm{HCO}_{3}^{-}\right]$) is necessary for respiratory acclimatization.

What then is the mechanism of this reduction in CSF $\left[\mathrm{HCO}_{3}^{-}\right]$? It used to be assumed that hyperventilation was initiated by hypoxic stimulation of the peripheral chemoreceptors. This would cause a respiratory alkalosis, stimulating the kidneys to excrete an alkaline urine, resulting in a reduction in blood $\left[\mathrm{HCO}_{3}^{-}\right]$and passively of $\mathrm{CSF} \mathrm{HCO}_{3}^{-}$.

This mechanism was found to be inadequate because: 1) The arterial $\mathrm{pH}$ becomes progressively more alkaline during the early stages of acclimatization (Nielsen and Smith, 1952 - appendix to paper); and 2) Kellogg in 1963 showed that the time course for the change in blood pH and the shift in the $\mathrm{CO}_{2}$ response curve were quite different, the latter being much more rapid, so that after the first few days, the $\mathrm{Pco}_{2}$ was $14 \mathrm{~mm} \mathrm{Hg}$ lower, while the arterial pH was 0.05 units higher than sea level values. He suggested that the chemical environment of the respiratory center was changed by some other, as yet unidentified, mechanism -- possibly active transport.

In 1963 Severinghaus, Mitche11, Richardson and Singer reported results of acid-base measurements on blood and CSF in man at altitude which they thought could best be explained by active transport of either $\mathrm{HCO}_{3}^{-}$or $\mathrm{H}^{+}$ 
across the blood-brain barrier. This hypothesis was developed by Mitche11, Carmen, Severinghaus, Richardson, Singer and Shnider (1965) and has received support from Pappenhiemer et a1. (1965) and Fencl, Miller and Pappenheimer (1966). This is further discussed later.

The mechanism of acclimatization then would be: Hypoxia $\rightarrow$ peripheral chemoreceptor stimulation $\rightarrow \mathrm{PCO}_{2} \downarrow$ in blood and CSF $\rightarrow$ active transport of $\mathrm{HCO}_{3}^{-}$out or $\mathrm{H}^{+}$into $\mathrm{CSF}$ under the influence of some pH regulating mechanism.

\section{RESULTS OF PRESENT WORK}

B lood

The acid-base balance of the arterial blood in our subjects at high altitude showed the well known respiratory alkalosis with compensatory metabolic acidosis. In lowlanders at 4,880 $\mathrm{m}$ this compensation is incomplete and a further reduction of $1.5 \mathrm{mEq} / 1\left[\mathrm{HCO}_{3}^{-}\right]$would be required to bring the $\mathrm{pH}$ to 7.40 . This slightly increased $\mathrm{pH}$ is in accordance with other workers (Kellogg, 1963; Pauli, Vorburger and Reuben, 1962; and Severinghaus et a1., 1963). High altitude natives on the other hand seem to compensate completely. Hurtado and Aste-Salazar (1948) and Chiodi (1957) also found this same difference between residents and new-comers to high altitude.

\section{Cerebrospinal fluid}

Our results can best be compared with those of Severinghaus et al. (1963) and Severinghaus and Carcelen (1964).

Lowlanders. The alkalosis that results from a reduction in $\mathrm{PCO}_{2}$ on going to altitude is more rapidly corrected in the CSF than in the arterial blood. 
In dogs Miche1 (1963) showed a fall in CSF $\mathrm{HCO}_{3}^{-}$of over $5 \mathrm{mEq} / 1$ within the first hour of hyperventilation. Severinghaus et a1. (1963) found the CSF pH to be almost normal by the second day at altitude (their first sampling), while the arterial pH was stil1 raised (7.485). There was little further change on either blood or CSF by the eighth day. They interpreted their results as suggesting a mechanism which regulated $\mathrm{CSF}$ pH by active transport of $\mathrm{HCO}_{3}^{-}$out of the CSF against the gradient, into blood.

Our results, at a higher altitude, with lower CSF $\mathrm{PCO}_{2}$ showed a more alkaline CSF pH. This is evidence against very close regulation of CSF $\mathrm{pH}$ to sea level values.

Sherpas and Andean natives. Severinghaus and Carcelen (1964) found the mean CSF in Andean natives at $4,300 \mathrm{~m}$ to be 7.336 . In the same population and at similar altitude, we found the mean CSF pH to be 7.291 \pm 0.016 . We have no satisfactory evidence for this discrepancy, though they mention some alteration in the $\mathrm{pH}$ of their buffer during transportation and possibly the discrepancy may be partly due to this cause.

The difference between our results in Sherpas at 4,880 m (pH 7.328) and Andean natives at $4,330 \mathrm{~m}$ ( $\mathrm{pH} 7.291$ ) is presumably due to the difference in $\mathrm{PCO}_{2}, 37.7$ and $47.1 \mathrm{~mm} \mathrm{Hg}$ respectively, resulting in part from difference in altitude. The Sherpas are normally resident at about $4,000 \mathrm{~m}$ and so we studied them at almost $900 \mathrm{~m}$ above their place of residence. They may have undergone a degree of acclimatization analagous to lowlanders resulting in a shift of CSF pH towards the alkaline side. 
In our Andean subjects the arterial $\mathrm{CSF} \mathrm{PCO}_{2}$ gradient was greater than normal $(13 \mathrm{~mm} \mathrm{Hg})$. As part of the study of cerebral metabolism we measured cerebral arterial-venous $\mathrm{O}_{2}$ difference and were surprised to find a high value of 7.89 vols per cent indicating a low cerebral blood flow. The CSF $\mathrm{PCO}_{2}$ is in equilibrium with cerebral venous blood, and so the large arterial-CSF gradient is presumably due to this low cerebral blood flow. W'e have no data on cerebral blood flow in our sherpa or lowland subjects but there may be important differences in cerebral blood flow response to hypoxia in these three groups, since in lowlanders at an altitude of $3,810 \mathrm{~m}$ Severinghaus, Chiodi, Eger, Brandstater and Hornbein (1966) found cerebral blood flow to be increased 24 per cent at $6-12$ hours and 13 per cent at 3-5 days after arrival.

\section{CSF $\mathrm{pH}$ regulation}

The rather wide range of CSF $\mathrm{pH}$ values we have found is evidence against any mechanism which accurately regulates CSF pH by active transport of $\mathrm{HCO}_{3}^{-}$or $\mathrm{H}^{+}$across the blood-brain barrier. The mechanism of any such homeostatic system must require a signal in a form of a disturbance of the homeostasis. In hyperventilation the signal would be a slight rise in $\mathrm{pH}$ due to respiratory alkalosis. This would cause the active transport of $\mathrm{HCO}_{3}^{-}$out of the CSF against the concentration gradient. If the system were perfectly efficient, the signal necessary would be immeasurably small and the $\mathrm{pH}$ would be restored exactly to normal values. If the system were less than perfect, the CSF pH would remain alkaline. But in no way could the system pump out $\mathrm{HCO}_{3}^{-}$to a point where the $\mathrm{pH}$ was lower than normal since before then the signal would be reversed, and $\mathrm{HCO}_{3}$ would be retained. Therefore, the low pH found in Andean natives is the strongest evidence against such a mechanism. 
Our findings suggest a hypothesis that CSF $\mathrm{pH}$ is primarily reduced by some means other than hyperventilation, and that hyperventilation is secondary, a result of this resetting of the central chemostat. Three other pieces of evidence also support the hypothesis that acclimatization is not primarily the result of hyperventilation:

1) Natives to high altitude who have very little or no hypoxic sensitivity nevertheless acclimatize to about the same extent as lowlanders in terms of $\mathrm{CSF} \mathrm{HCO}_{3}^{-}$and shift of the $\mathrm{CO}_{2}$ response curve (Severinghaus, Bainton and Carcelen, 1966; and the present work, Chapter IV).

2) Eger, Kellogg, Mines, Lima-Ostos, Morrill and Kent (1968) have shown a greater shift in the $\mathrm{CO}_{2}$ response curve in human subjects hyperventilating for 8 hours with hypoxia compared with similar hyperventilation wi thout hypoxia.

3) Sorensen and Mines (1968) have shown that goats with their carotid bodies denervated so that acute hypoxia depressed ventilation, nevertheless shifted their hyperoxic $\mathrm{CO}_{2}$ response curve at altitude to the same extent as normal goats.

These all indicate that hypoxia has an effect on respiratory acclimatization apart from any effect through the peripheral chemoreceptor. The findings could be explained if the reduction of $\mathrm{CSF} \mathrm{HCO}_{3}^{-}$was a primary effect of hypoxia. This primary effect of hypoxia in lowering CSF $\mathrm{HCO}_{3}^{-}$could be via the metabolites of anaerobic metabolism, e.g., lactic and pyruvic acid.

Anaerobic glycolysis, the basis for acclimatization

Severinghaus et a1. (1963) considered the effect of the rise in lactic acid on CSF $\mathrm{HCO}_{3}^{-}$but thought it unimportant. Taking their sea 
observed. In this way the highlander has a greater central respiratory drive that largely masks the lack of peripheral drive and accounts for his respiratory acclimatization.

It is suggested therefore, that the major cause for the reduction in $\mathrm{CSF}\left(\mathrm{HCO}_{3}^{-}\right)$in respiratory acclimatization is a metabolic acidosis from continuing anaerobic metabolism in the brain. The major role of the peripheral chemoreceptors would seem to be that of counteracting the central depression caused by hypoxia which is seen in animals with peripheral chemoreceptor denervation. 
level value, our subjects in 1964 showed a rise in CSF lactate of 1.8

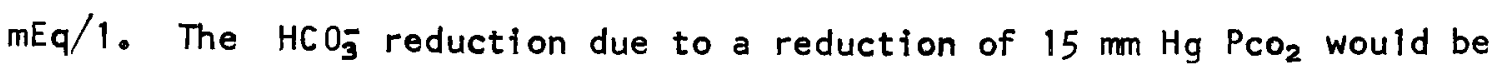
$0.3 \mathrm{mEq} / 1$ which together accounts for $2.1 \mathrm{mEq} / 1$ out of a total $\mathrm{HCO}_{3}^{-}$ reduction of $4.9 \mathrm{mEq} / 1$ in lowlanders and $5.6 \mathrm{mEq} / 1$ in Sherpas.

It may be that the lactate level found in the CSF does not reflect the extent of acidosis actually resulting from anaerobic metabolism. This could be either because $\mathrm{H}^{+}$is more diffusible than the lactate ion, or because the $\mathrm{H}^{+}$is pumped out of the cell in the same way, or even by the same mechanism as $\mathrm{Na}^{+}$is pumped. Thus although the measured rise in CSF lactate may be sma11, the increase in $\mathrm{H}^{+}$which combines with $\mathrm{HCO}_{3}^{-}$may we 11 be of the order of $4-6 \mathrm{mEq} / 1$.

Such an explanation would be in agreement with our findings and those of other workers. The observed rapid reduction in $\mathrm{CSF} \mathrm{HCO}_{3}^{-}$on going to altitude would be due to diffusion or pumping of $\mathrm{H}^{+}$out of cells as metabolism changed to a degree of anaerobic glycolysis in the face of hypoxia. Hyperventilation results in similar changes due to a reduction in cerebral blood flow causing tissue hypoxia.

The differences in CSF pH between lowlanders and highlanders could then be accounted for by the differences in peripheral chemoreceptor response that we have shown (Chapter IV). In lowlanders the strong hypoxic ventilatory response further lowers $\mathrm{PCO}_{2}$ resulting in a slight alkalosis in the CSF (and blood) and a reduction in central respiratory drive, while the highlanders with a weaker hypoxic response, have a slightly higher CSF $\mathrm{PCO}_{2}$. For the same reason, the highlander also has a lower $\mathrm{PO}_{2}$ and possibly a lower cerebral blood flow, which results in a greater cerebral lactic acid production giving a slightly lower CSF $\left[\mathrm{HCO}_{3}^{-}\right]$. The higher $\mathrm{PCO}_{2}$ and lower $\left[\mathrm{HCO}_{3}^{-}\right]$result in the lower $\mathrm{CSF} \mathrm{pH}$ 


\section{REFERENCES}

Chapter VI

Barker, S. B. and W. H. Summerson (1941). Colorimetric determination of lactic acid in biological material. J. Biol. Chem. 138, 535.

Bradley, R. D. and S. J. G. Semple (1962). A comparison of certain acidbase characteristics of arterial blood, jugular venous blood and CSF in man, and the effect on them of some acid-base disturbances. J. Physio1., London, 160, 381-391.

Chiodi, H. (1957). Respiratory adaptations to chronic high altitude hypoxia. J. App 1. Physio1. 10, 81-87.

Cunningham, D. J. C., D. J. Shaw, S. Lahiri and B. B. Lloyd (1961). The effect of maintained ammonium chloride acidosis on the relation between pulmonary ventilation and alveolar oxygen and carbon dioxide in man. Quart. J. Exp. Physiol. 46, 323-334.

Eger, E. T., R. H. Ke 1 logg, A. H. Mines, M. Lima Ostos, C. G. Morril1 and $D . W$. Kent (1968). The influence of $\mathrm{CO}_{2}$ on ventilatory acclimatization to altitude. J. App1. Physio1. 24, 607-615.

Fenc1, V., T. B. Miller and J. R. Pappenheimer (1966). Studies on the respiratory response to disturbances of acid-base balance, wi th deductions concerning the ionic composition of cerebral interstitial fluid. Am. J. Physio1. 210, 459-472.

Fisher, V. J. and L. C. Christianson (1963). Cerebrospinal fluid acidbase balance during a changing ventilatory state in man. J. Appl. Physio1. 18, 712-716.

Hurtado, A. and H. Aste-Salazar (1948). Arterial blood gases and acidbase balance at sea level and at high altitude. J. Appl. Physiol. $1,304-325$.

Kellogg, R. H. (1963). The role of $\mathrm{CO}_{2}$ in altitude acclimatization; in Regulation of Human Respiration, edited by $D . J . C$. Cunningham and B. B. Lloyd. Oxford: Blackwe11, pp. 379-394.

Miche1, C. C. (1963). CSF $\mathrm{HCO}_{3}^{-}$during respiratory acid-base disturbance. J. Physio1., London, 170, 66-67P.

Mitche11, R. A., H. H. Loeschcke, W. H. Massion and J. W. Severinghaus (1963). Respiratory responses mediated through superficial chemosensitive areas on the medulla. J. Appl. Physiol. 18, 523-533. 
Mitche 11, R.A., C.T. Carman, J.W.Severinghaus, M.M. Singer, and S.Shnider (1965). Stability of cerebrospinal fluid $\mathrm{pH}$ in chronic acid-base disturbances in blood. J. Appl. Physio1. 20, 443-452.

Nie1sen, M. and H. Smith (1952). Studies on the regulation of respiration in acute hypoxia. Acta Physio1. Scand. 24, 293-313.

Pappenheimer, J. R., V. Fenc1, S. R. Heisey and D. Held (1965). Role of cerebral fluids in control of respiration as studied in anesthetized goats. Am. J. Physio1. 208, 436-450.

Pauli, H. Go, C. Vorburger and F. Reubi (1962). Chronic derangements of cerebrospinal fluid acid-base components in man. J. App1. Physiol. $17,993-998$.

Severinghaus, J. W., M. Stupfel and A. F. Bradley (1956). Accuracy of blood $\mathrm{pH}$ and $\mathrm{PCO}_{2}$ determinations. J. App1. Physiol. 9, 189-196.

Severinghaus, J. W., R. A. Mitche11, B. W. Richardson and M. M. Singer (1963). Respiratory control at high altitude suggesting active transport regulation of CSF pH. J. Appl. Physio1. 18, 1155-1166.

Severinghaus, J. W. and A. Carcelen (1964). Cerebrospinal fluid in man native to high altitude. J. App1. Physio1. 19, 319-321.

Severinghaus, J. W., H. Chiodi, E. I. Eger II, B. Brandstater and T. F. Hornbein (1966). Cerebral blood flow in man at high altitude. Circulation Res. 19, 274-282.

Severinghaus, J. W., C. R. Bainton and A. Carcelen (1966). Respiratory insensitivity to hypoxia in chronically hypoxic man. Resp. Physiol. $1,308-334$.

Sorensen, S. C. and A. H. Mines (1968). The effect of bilateral nerve sectior. on the ventilatory response to $\mathrm{CO}_{2}$ and on acclimatization to chronic hypoxia in awake goats. Proc. XXIV Internat. Congress of Physio1. Sci. Washington, 1968. (Abstract) 